\title{
Push or Pull? Proton Responsive Ligand Effects in Rhenium Tricarbonyl $\mathrm{CO}_{2}$ Reduction Catalysts
}

\author{
Gerald F. Manbeck, ${ }^{*}+$ James T. Muckerman, $^{\dagger}$ David J. Szalda, ${ }^{\dagger} \ddagger$ Yuichiro Himeda, \\ and Etsuko Fujita*,
}

\author{
${ }^{\dagger}$ Department of Chemistry, Brookhaven National Laboratory, Upton, NY 11973, United States \\ ${ }^{\ddagger}$ Department of Natural Science, Baruch College, CUNY, New York, New York 10o10, United States \\ ${ }^{\S}$ National Institute of Advanced Industrial Science and Technology, Tsukuba Central 5-2, 1-1-1 Higashi, Tsukuba, \\ Ibaraki, 305-8565, Japan, and Japan Science and Technology Agency, ACT-C, 4-1-8, Honcho, Kawaguchi, Saitama, \\ 332-0012, Japan
}

Supporting Information Placeholder

\begin{abstract}
Proton responsive ligands offer control of catalytic reactions through modulation of pH-dependent properties, second coordination sphere stabilization of transition states, or by providing a local proton source for multi-proton, multi-electron reactions. Two $f a c$ - $\left[\operatorname{ReI}(\alpha\right.$-diimine $\left.)(\mathrm{CO})_{3} \mathrm{Cl}\right]$ complexes with $\alpha$-diimine $=4,4^{\prime}$ - (or $\left.6,6^{\prime}-\right)$ dihydroxy-2,2'-bipyridine (4DHBP and 6DHBP) have been prepared and analyzed as electrocatalysts for reduction of carbon dioxide. Consecutive electrochemical reduction of these complexes yields species identical to those obtained by chemical deprotonation. An energetically feasible mechanism for reductive deprotonation is proposed in which the bpy anion is protonated followed by loss of $\mathrm{H}_{2}$ and $2 \mathrm{H}^{+}$. Cyclic voltammetry reveals a two-electron, three-wave system owing to competing EEC and ECE pathways. The chemical step of the ECE pathway might be attributed to the reductive deprotonation. but cannot be distinguished from chloride dissociation. The rate obtained by digital simulation is approximately $8 \mathrm{~s}^{-1}$. Under $\mathrm{CO}_{2}$, these competing reactions generate a two-slope catalytic waveform with onset potential of $-1.65 \mathrm{~V} \mathrm{vs} \mathrm{Ag} / \mathrm{AgCl}$. $\mathrm{Reduction}$ of $\mathrm{CO} 2$ to $\mathrm{CO}$ by the $\left[\mathrm{Re}^{\mathrm{l}}\left(4 \mathrm{DHBP}-2 \mathrm{H}^{+}\right)(\mathrm{CO})_{3}\right]^{-}$suggests the interaction of $\mathrm{CO}_{2}$ with the deprotonated species or a third reduction followed by catalysis. Conversely, the reduced form of $\left[\mathrm{Re}(6 \mathrm{DHBP})(\mathrm{CO})_{3} \mathrm{Cl}\right]$ converts $\mathrm{CO}_{2}$ to $\mathrm{CO}$ with a single turnover.
\end{abstract}

\section{INTRODUCTION}

Advances in the chemistry of carbon dioxide are needed to enable efficient, cost-effective methods for recycling the endproduct of combustion into liquid fuels and $\mathrm{C} 1$ chemicals. $^{1-6}$ Direct electrochemical reduction of $\mathrm{CO}_{2}$ is unfavorable with $E^{0}$ $\left(\mathrm{CO}_{2} / \mathrm{CO}_{2}{ }^{--}\right)=-1.90 \mathrm{~V}$ vs. NHE in water at $\mathrm{pH} 7$, but the energy requirement for $\mathrm{CO}_{2}$ reduction is substantially lower for protonassisted, multi-electron processes. For example, the standard potential for the 8-proton, 8-electron reduction of $\mathrm{CO}_{2}$ to methane and $\mathrm{H}_{2} \mathrm{O}$ is only $-0.24 \mathrm{~V}$ vs. NHE at $\mathrm{pH} 7$; however, the difficulty of orchestrating numerous electron- and proton-transfer steps becomes a kinetic limitation. Transition metal catalysts are wellsuited to mediate the electron transfers and bond formations necessary for $\mathrm{CO}_{2}$ activation and reduction and provide selectivity for a single product in many cases.

The $f a c$ - $\left[\operatorname{Re}(\alpha \text {-diimine })(\mathrm{CO})_{3} \mathrm{X}\right]^{\mathrm{n}+}(\mathrm{X}=$ halide; $\mathrm{n}=0$ or $\mathrm{X}=$ neutral ligand, $\mathrm{n}=1$ ) family of complexes selectively catalyzes the reduction of $\mathrm{CO}_{2}$ to $\mathrm{CO} .^{7-19}$ Electrocatalysis is effective in solution and using surface-bound catalysts while photochemical systems have been identified with or without separate sensitizers. Mechanistic studies have revealed one-electron or two-electron pathways for catalysis. The photocatalytic one-electron chemistry relies on the $\alpha$-diimine ligand functioning as an electron reservoir while imparting radical character to the Re center, thus providing properties different from the typical $17 \mathrm{e}^{-}$metal complexes such as $\mathrm{Re}^{\circ}(\mathrm{CO})_{5}{ }^{20}$ As an illustration of $1 \mathrm{e}^{-}$chemistry, $\left[\mathrm{Re}(\mathrm{dmb})(\mathrm{CO})_{3} \mathrm{Cl}\right]^{-} \quad\left(\mathrm{dmb}=4,4^{\prime}\right.$-dimethyl-2,2'-bipyridine $)$ undergoes dissociative substitution of $\mathrm{Cl}^{-}$by solvent to produce the ligand radical, $\left[\operatorname{Re}\left(\mathrm{dmb}^{{ }^{-}}\right)(\mathrm{CO})_{3}(\mathrm{~S})\right](\mathrm{S}=\text { solvent })^{11,21}$ Reaction of two metal radicals with $\mathrm{CO}_{2}$ is slow $\left(k \sim 0.003 \mathrm{~s}^{-1}\right)$ due to equilibrium in favor of the six-coordinate ligand radical over the five-coordinate Re-centered radical. The product is a $\mu_{2}-$
$\eta^{2}-\mathrm{CO}_{2}$ bridged species which reacts with $\mathrm{CO}_{2}$ as an oxide acceptor to produce $\mathrm{CO}$ and $\mathrm{CO}_{3}{ }^{2-}$. The two-electron pathway is expected to dominate electrochemically and involves $\eta^{1}$ coordination of $\mathrm{CO}_{2}$ to the five-coordinate anion $[\operatorname{Re}(\alpha-$ diimine $\left.(\mathrm{CO})_{3}\right]^{-22}$ Recent experimental results supported by DFT calculations have revealed the reaction of ${ }^{13} \mathrm{CO}_{2}$ with $\left[\operatorname{Re}(\mathrm{dmb})(\mathrm{CO})_{3}(\mathrm{COOH})\right]$ to produce $\mathrm{CO}$ and the bicarbonate product $\left[\mathrm{Re}(\mathrm{dmb})(\mathrm{CO})_{3}\left(\mathrm{O}^{13} \mathrm{CO}_{2} \mathrm{H}\right)\right] .^{23}$ In practical consideration, $\mathrm{CO}$ is an ideal target since it readily separates from the reaction mixture and can be used in the synthesis of liquid alkanes by the Fisher-Tropsch process.

Recent research efforts in our group and others have focused on catalytic hydrogenation of $\mathrm{CO}_{2}$ to formic acid or the reverse dehydrogenation of formic acid using transition metal complexes of hydroxy-bipyridine type ligands. ${ }^{24-30}$ Hydrogenation of $\mathrm{CO}_{2}$ using $\mathrm{Rh}$, Ir, and $\mathrm{Ru}$ complexes of 4,4'-dihydroxy-2,2'-bipyridine (4DHBP) is enhanced in basic media due to the acid/base equilibrium of the ligand and the strong electron donating property in the oxyanion form (Figure 1). Ligands with the $\mathrm{OH}$ group adjacent to the metal center experience the electronic effects of deprotonation and also exploit the oxyanion as a pendant base adjacent to the catalytic site. Reversible hydrogen storage has been demonstrated by $\left[\{\mathrm{Cp} * \operatorname{Ir}(\mathrm{Cl})\}_{2}(\text { thbpm })\right]^{2+}\left(\mathrm{Cp}^{*}\right.$ $=$ pentamethylcyclopentadiene, thbpm $=4,4^{\prime}, 6,6^{\prime}$-tetrahydroxy2,2'-bipyrimidine) which catalyzes $\mathrm{CO}_{2}$ hydrogenation at high $\mathrm{pH}$ as the oxyanion and formic acid dehydrogenation at low $\mathrm{pH}$ as the pyridinol form. ${ }^{26}$ The proximal base lowers the activation energy for heterolytic cleavage of $\mathrm{H}_{2}$ to form the metal hydride which then undergoes insertion of $\mathrm{CO}_{2} .{ }^{30}$ 


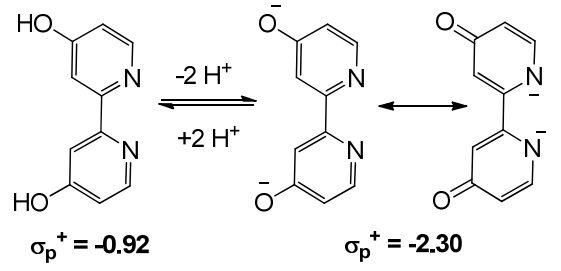

Figure 1. 4,4'-dihydroxy-2,2'-bipyridine acid-base equilibrium and Hammett values.

To the best of our knowledge, the 4DHBP or 6DHBP ligands have not been studied for $\mathrm{CO}_{2}$ reduction using rhenium tricarbonyl catalysts. The highly active electrocatalyst, $\left[\mathrm{Re}\left({ }^{t} \mathrm{Bu}_{2}\right.\right.$ bpy $\left.)(\mathrm{CO})_{3} \mathrm{Cl}\right] \quad\left({ }^{t} \mathrm{Bu}_{2}\right.$ bpy $=4,4^{\prime}$-di-tert-butyl-2,2'bipyridine) has been identified for $\mathrm{CO}_{2}$ reduction, but the origin of improved catalysis remains ambiguous. ${ }^{31}$ One suggested explanation is greater nucleophilicity of the Re center in reduced species due to electron-donating ${ }^{t} \mathrm{Bu}$ groups although the activity comes at the expense of a greater overpotential. Based on precedent for $\mathrm{CO}_{2}$ hydrogenation, we hypothesized that the influence of electron donation could be pushed to the extreme using 4DHBP and 6DHBP. Furthermore, there is increasing interest in designing electrocatalysts for $\mathrm{CO}_{2}$ reduction with pendant acids since typical mechanisms proceed through $[\mathrm{M}-$ $\mathrm{COOH}]$ intermediates generated by protonation of $\left[\mathrm{M}-\mathrm{CO}_{2}\right]$ species. $^{32,22}$

This paper reports the preparation, physical properties, and application in $\mathrm{CO}_{2}$ reduction electrocatalysis of $\left[\operatorname{Re}(4 \mathrm{DHBP})(\mathrm{CO})_{3} \mathrm{Cl}\right]$ and $\left[\operatorname{Re}(6 \mathrm{DHBP})(\mathrm{CO})_{3} \mathrm{Cl}\right]$. Unexpectedly, we have discovered reductive electrolytic deprotonation of the ligands proven by full and partial chemical deprotonation in combination with spectroelectrochemical IR (SEC-IR) experiments. To the best of our knowledge this is the first example for $\operatorname{Re}(\mathrm{CO})_{3}$ complexes of this process happening twice and also on the same ligand that accepts the electron. This phenomenon nullifies the "push" of the electron-donating substituents which instead exert a "pull" since the reduction occurs primarily at ligand sites. Despite this "pull", $\left[\mathrm{Re}(4 \mathrm{DHBP})(\mathrm{CO})_{3} \mathrm{Cl}\right]$ is still a viable $\mathrm{CO}_{2}$ reduction electrocatalyst which likely requires a third electron to initiate catalysis. The $\left[\operatorname{Re}(6 \mathrm{DHBP})(\mathrm{CO})_{3} \mathrm{Cl}\right]$ reacts stoichiometrically with $\mathrm{CO}_{2}$.

\section{EXPERIMENTAL DETAILS}

2.1. General. The ligands $4,4^{\prime}$-dihydroxy-2,2'-bipyridine, $6,6^{\prime}$ dihydroxy-2,2'-bipyridine ${ }^{33,79}$ and known complexes $\left[\mathrm{Re}\left({ }^{t} \mathrm{Bu}_{2} \mathrm{bpy}\right)(\mathrm{CO})_{3} \mathrm{Cl}\right]$ and $\left[\mathrm{Re}\left(\mathrm{OMe}_{2} \mathrm{bpy}\right)(\mathrm{CO})_{3} \mathrm{Cl}\right]^{31}$ were prepared according to literature procedures. $\mathrm{Re}(\mathrm{CO})_{5} \mathrm{Cl}$ was purchased from Aldrich. Anhydrous DMF, $\mathrm{CD}_{3} \mathrm{CN}$, and $\mathrm{CH}_{3} \mathrm{CN}$ were stored over activated molecular sieves under Ar. Electrospray mass spectra (ESI-MS) were measured using a Thermo Finnigan mass spectrometer. NMR spectra were recorded on a $400 \mathrm{MHz}$ Bruker Avance spectrometer at room temperature. Chemical shifts in ppm are referenced to the solvent peaks. NMR spectra of deprotonated complexes (i.e., with the oxyanion ligand) were measured by first dissolving the complex in $\mathrm{CD}_{3} \mathrm{CN}$ in a $\mathrm{J}$ Young tube then adding 2 eq. $\mathrm{Bu}_{4} \mathrm{NOH}$ as a $1 \mathrm{M}$ solution in $\mathrm{MeOH}$. Solutions were stable for at least 3 hours. If the mixtures were taken to dryness and re-dissolved in $\mathrm{CD}_{3} \mathrm{CN}$, several minor species were present. Thus, data in Table 1 are chemical shifts prior to evaporation of the $\mathrm{MeOH}$ and $\mathrm{H}_{2} \mathrm{O}$ generated by deprotonation. NMR spectra of reduced complexes were obtained by electrolyzing $\left[\operatorname{Re}(4 \mathrm{DHBP})(\mathrm{CO})_{3} \mathrm{Cl}\right]$ or $\left[\operatorname{Re}(6 \mathrm{DHBP})(\mathrm{CO})_{3} \mathrm{Cl}\right]$ in $\mathrm{CD}_{3} \mathrm{CN}$ with $0.1 \mathrm{M} \mathrm{Bu}_{4} \mathrm{NPF}_{6}$ under Ar. After consumption of two equivalents of charge, an aliquot was rapidly transferred to a
J-Young tube with positive argon flow. The solution was immediately frozen in liquid nitrogen then degassed by three freeze-pump-thaw cycles under high vacuum to remove any air contamination. Electronic absorption spectra were measured using an Agilent 8453 diode array spectrophotometer. Aqueous $\mathrm{pH}$ titrations were carried out in Britton-Robinson buffer and $1 \%$ $\mathrm{CH}_{3} \mathrm{CN}$ co-solvent. Starting at $\mathrm{pH} \sim 1.5$, the $\mathrm{pH}$ was adjusted with concentrated $\mathrm{NaOH} . \mathrm{p} K_{\mathrm{a}}$ values were determined from the sigmoidal least-squares fit of $\varepsilon$ vs. $\mathrm{pH}$. Cyclic voltammograms (CVs) were recording using a three-electrode configuration with a glassy carbon working electrode and $\mathrm{Pt}$ counter electrode. The reference electrode was $\mathrm{Ag} / \mathrm{AgCl}(3 \mathrm{M} \mathrm{KCl})$ separated from the working solution by two Vycor frits and the supporting electrolyte was $0.1 \mathrm{M} \mathrm{Bu}_{4} \mathrm{NPF}_{6}$. The reference was calibrated internally using ferrocene. Spectroelectrochemical UV-vis experiments were performed in a standard $\mathrm{H}$-cell using a $\mathrm{Pt}$ mesh working electrode. Simulated voltammograms were generated using Digisim ${ }^{34}$ Preparative-scale electrolysis experiments were performed in a three compartment cell with fine porosity glass frits separating each compartment. The working electrode was a $5 \mathrm{~cm}^{2}$ mercury pool connected through a Pt wire sealed in glass. The uncompensated cell resistance was approximately $30 \Omega$. Gaseous products were analyzed by GC on an Agilent $6890 \mathrm{~N}$ GC with HP$\operatorname{MOLSIV}(30 \mathrm{~m} \times 0.32 \mathrm{~mm} \times 1.5 \mu \mathrm{m})$ and GS-CARBON-PLOT $(15 \mathrm{~m} \times 0.32 \mathrm{~mm} \times 1.5 \mu \mathrm{m})$ columns. $\mathrm{CO}$ was quantified via a methanizer by a calibrated FID detector. Spectroelectrochemical IR (SEC-IR) experiments were performed using an OTTLE cell from Specac equipped with a gold mini-grid working electrode, $\mathrm{Rh}$ counter electrode, an Ag wire pseudo-reference electrode and $\mathrm{CaF}_{2}$ windows. Solutions were approximately $1 \mathrm{mM}$ Re complex and $100 \mathrm{mM} \mathrm{Bu} \mathrm{NPF}_{6}$. Solutions were purged with Ar prior to introduction into the cell via syringe. Background scans were collected using pure solvent without electrolyte. Data were collected as an average of 2-4 scans with $2 \mathrm{~cm}^{-1}$ resolution using a MCT detector. Details of X-ray crystallography and DFT calculations are provided as Supporting Information.

2.2. Synthesis of $\left[\operatorname{Re}(4 \mathrm{DHBP})(\mathrm{CO})_{3} \mathrm{Cl}\right]$. $4 \mathrm{DHBP}(52.0 \mathrm{mg}$, $0.284 \mathrm{mmol})$ in $\mathrm{MeOH}(1 \mathrm{~mL})$ and toluene $(8 \mathrm{~mL})$ was heated until the ligand dissolved and $\mathrm{Re}(\mathrm{CO})_{5} \mathrm{Cl}(100 . \mathrm{mg}, 0.284 \mathrm{mmol})$ was added in a single portion. The mixture was heated at reflux for $1 \mathrm{~h}$ then allowed to stand at room temperature for 5 days after which a crop of yellow microcrystals was collected by filtration, washed with diethyl ether, and dried under vacuum to provide 95 $\mathrm{mg}(70 \%$ yield $)$. X-ray quality crystals were grown by evaporation of a mixture of DMSO and acetone. $v_{\mathrm{CO}}$ (DMF): 2015, 1907, 1885. ${ }^{1} \mathrm{H}$ NMR $\left(\mathrm{CD}_{3} \mathrm{CN}, \mathrm{RT}\right): \delta 9.03(\mathrm{~s},-\mathrm{OH}), 8.66$ (d, J = 8.7), 7.69 (d, $J=2.5), 7.03$ (dd, J = 7.0, 2.5). ESI-MS(+): $m / z$ calcd for $\left[\mathrm{M}-\mathrm{HCl}+\mathrm{CH}_{3} \mathrm{OH}+\mathrm{Na}^{+}\right]^{+} 516.0$, found $516.7 ;[\mathrm{M}$ $\left.-\mathrm{CO}+\mathrm{Na}^{+}\right]^{+}$491.0, found 490.7. Anal. calc'd: C, 31.62; H, 1.63; $\mathrm{N}$, 5.67. found: $\mathrm{C} 31.33 ; \mathrm{H}, 1.64 ; \mathrm{N}, 5.55$. UV-vis, $\mathrm{CH}_{3} \mathrm{CN}, \lambda_{\max }$ $\left(\varepsilon / \mathrm{M}^{-1} \mathrm{~cm}^{-1}\right): 193$ (64,200), 223 (41,100), $254(22,200), 348$ (3700); $\left[\mathrm{Re}\left(4 \mathrm{DHBP}-2 \mathrm{H}^{+}\right)(\mathrm{CO})_{3}\right]^{-}: 193(114,200), 255(56,700)$, $342(11,600)$.

2.3. Synthesis of $\left[\operatorname{Re}(6 \mathrm{DHBP})(\mathrm{CO})_{3} \mathrm{Cl}\right]$. The procedure for $\left[\operatorname{Re}(4 \mathrm{DHBP})(\mathrm{CO})_{3} \mathrm{Cl}\right]$ was followed using 6DHBP (104 mg, $0.568 \mathrm{mmol})$ and $\operatorname{Re}(\mathrm{CO})_{5} \mathrm{Cl}(200 \mathrm{mg}, 0.568 \mathrm{mmol})$. After cooling to room temperature, the product was isolated by precipitation with diethyl ether, collected by vacuum filtration, and dried under vacuum to provide $273 \mathrm{mg}$ (71\% yield). $v_{\mathrm{CO}}$ (DMF): 2016, 1911, 1878. ${ }^{1} \mathrm{H}$ NMR $\left(\mathrm{CD}_{3} \mathrm{CN}, \mathrm{RT}\right): \delta 9.74(\mathrm{~s},-$ $\mathrm{OH}), 7.93(\mathrm{t}, \mathrm{J}=7.9), 7.84(\mathrm{~d}, \mathrm{~J}=8.1), 7.09(\mathrm{~d}, \mathrm{~J}=8.1)$. ESI$\mathrm{MS}(+): m / z$ calcd for $\left[\mathrm{M}-\mathrm{HCl}+\mathrm{CH}_{3} \mathrm{OH}+\mathrm{Na}^{+}\right]^{+}$516.0, found 516.7; $\left[\mathrm{M}-\mathrm{CO}+\mathrm{Na}^{+}\right]^{+}$491.0, found 490.7. Anal. calc'd: C, 31.62; H, 1.63; N, 5.67. found: C 31.61; H, 1.56; N, 5.70. UV-vis, 
$\mathrm{CH}_{3} \mathrm{CN}, \lambda_{\max }\left(\varepsilon / \mathrm{M}^{-1} \mathrm{~cm}^{-1}\right): 193(155,100), 332(27,000) 345$ $(32,400), 254$ (22,200), 400 (11,800); [Re(6DHBP-2 $\left.\left.\mathrm{H}^{+}\right)(\mathrm{CO})_{3}\right]^{-}$: $193(350,300), 395(36,400), 416(28,600)$.

\section{RESULTS AND DISCUSSION}

3.1. Synthesis and Characterization. The complexes $\left[\mathrm{Re}(4 \mathrm{DHBP})(\mathrm{CO})_{3} \mathrm{Cl}\right]$ and $\left[\operatorname{Re}(4 \mathrm{DHBP})(\mathrm{CO})_{3} \mathrm{Cl}\right]$ were obtained as analytically pure solids from the reaction of the ligands with $\mathrm{Re}(\mathrm{CO})_{5} \mathrm{Cl}$. The X-ray structure of $\left[\mathrm{Re}(4 \mathrm{DHBP})(\mathrm{CO})_{3} \mathrm{Cl}\right]$ (see Figure S1 and Tables S1-S3) confirmed bidentate $\alpha$-diimine coordination and the neutral pyridinol nature of the ligand. Bond distances and angles in the $\mathrm{Re}$ coordination sphere are nearly identical to the structure of $\left[\operatorname{Re}(b p y)(\mathrm{CO})_{3} \mathrm{Cl}\right] .^{12}$ The $2.0(2)^{\circ}$ dihedral angle between rings of 4DHBP is identical to $\left[\mathrm{Re}(\mathrm{bpy})(\mathrm{CO})_{3} \mathrm{Cl}\right]$. Strong hydrogen bonding between the hydroxyl groups of 4DHBP and the oxygen atom of a cocrystallized DMSO molecule was observed. (Table S3-S4).

NMR data (Table 1 and Figure S2) show three ${ }^{1} \mathrm{H}$ resonances for the bipyridine ligands in agreement with a facial arrangement of $\mathrm{CO}$ ligands. The $-\mathrm{OH}$ resonances of $\left[\mathrm{Re}(6 \mathrm{DHBP})(\mathrm{CO})_{3} \mathrm{Cl}\right]$ and $\left[\mathrm{Re}(4 \mathrm{DHBP})(\mathrm{CO})_{3} \mathrm{Cl}\right]$ appear at 9.76 and $9.02 \mathrm{ppm}$, respectively, in dry $\mathrm{CD}_{3} \mathrm{CN}$ but broaden in the presence of small quantities of $\mathrm{H}_{2} \mathrm{O}$. Although many possible coordination modes are possible for the 2-hydroxypyridine ligand, ${ }^{35}$ the appearance of the $-\mathrm{OH}$ resonance and bipyridine symmetry confirms bidentate $\alpha$-diimine coordination. Upon deprotonation, the ${ }^{1} \mathrm{H}$ resonances shift upfield, consistent with the electron-rich nature of the ligand expected from a change in $\sigma_{\mathrm{p}}{ }^{+36}{ }^{1} \mathrm{H}$ NMR were also measured after electrochemical reduction in which case resonances are also shifted upfield by $c a$. 0.7 to $1 \mathrm{ppm}$ from the parent complexes. The nature of these species will be discussed below.

Table 1. NMR data for $\left[\operatorname{Re}(4 \mathrm{DHBP})(\mathrm{CO})_{3} \mathrm{Cl}\right]$ and $\left[\operatorname{Re}(6 \mathrm{DHBP})(\mathrm{CO})_{3} \mathrm{Cl}\right]^{a}$

\begin{tabular}{lccc}
\hline Compound & isolated & $\begin{array}{c}\text { chemically } \\
\text { deprotonated }^{b}\end{array}$ & $\begin{array}{c}2 \mathrm{e}^{-} \\
\text {reduced }^{c}\end{array}$ \\
\hline$\left[\operatorname{Re}(4 \mathrm{DHBP})(\mathrm{CO})_{3} \mathrm{Cl}\right]^{d}$ & $9.02^{e}$ & & \\
& $8.66(\mathrm{~d})$ & $7.97(\mathrm{~d})$ & $7.99(\mathrm{~d})$ \\
& $7.69(\mathrm{~d})$ & $6.78(\mathrm{~d})$ & $6.89(\mathrm{~d})$ \\
& $7.03(\mathrm{dd})$ & $6.14(\mathrm{dd})$ & $6.16(\mathrm{dd})$ \\
{$\left[\operatorname{Re}(6 \mathrm{DHBP})(\mathrm{CO})_{3} \mathrm{Cl}\right]^{f}$} & $9.76^{e}$ & & \\
& $7.93(\mathrm{t})$ & $7.14(\mathrm{t})$ & $7.25(\mathrm{dd})$ \\
& $7.84(\mathrm{~d})$ & $6.64(\mathrm{~d})$ & $6.74(\mathrm{~d})$ \\
& $7.09(\mathrm{~d})$ & $6.13(\mathrm{~d})$ & $6.25(\mathrm{~d})$ \\
\hline
\end{tabular}

${ }^{a} \mathrm{ppm}$ in $\mathrm{CD}_{3} \mathrm{CN} .{ }^{b}$ Prepared in-situ using 2eq. $\mathrm{Bu}_{4} \mathrm{NOH} .{ }^{c}$ Prepared by electrochemical reduction in $\mathrm{CD}_{3} \mathrm{CN}$. ${ }^{d}$ Low field to high field: $\mathrm{H} 2, \mathrm{H} 5$, and $\mathrm{H} 3 .{ }^{e}$ Observed only in strictly anhydrous $\mathrm{CD}_{3} \mathrm{CN} .{ }^{f}$ Low field to high field: $\mathrm{H} 4, \mathrm{H} 5$, and $\mathrm{H} 3 . \mathrm{d}=$ doublet, $\mathrm{t}$ $=$ triplet, $\mathrm{dd}=$ doublet of doublets.

Three CO stretching bands in the solution IR spectra confirm the facial orientation of the CO ligands (Table 2). ${ }^{37}$ The $v(\mathrm{CO})$ for $\left[\mathrm{Re}(4 \mathrm{DHBP})(\mathrm{CO})_{3} \mathrm{Cl}\right]$ and $\left[\operatorname{Re}(6 \mathrm{DHBP})(\mathrm{CO})_{3} \mathrm{Cl}\right]$ are among the lowest energies reported for $\left[\mathrm{Re}(\alpha\right.$-diimine $\left.)(\mathrm{CO})_{3} \mathrm{Cl}\right]$ complexes due to increased $\operatorname{Re}(\mathrm{d} \pi) \rightarrow \mathrm{CO}$ backbonding. ${ }^{37,38}$ IR spectra were recorded with incremental addition of $\mathrm{Bu}_{4} \mathrm{NOH}$ and two stoichiometric deprotonation reactions were observed with each resulting in small red shifts of $v(\mathrm{CO})$ (Figures 4, 5, S11, S12 and Table 2). The three $\mathrm{CO}$ stretches for facial coordination were preserved, and no further changes in the spectra were observed with addition of excess base.

3.2. Electronic Absorption Spectra. Typical absorption spectra of $f a c$ - $\left[\mathrm{Re}(\alpha\right.$-diimine $\left.)(\mathrm{CO})_{3} \mathrm{Cl}\right]$ complexes exhibit broad, high energy MLCT bands with low oscillator strength. These properties are attributed to strong $\mathrm{d} \pi \rightarrow \pi^{*}(\mathrm{CO})$ back bonding and a large energy separation between the $\operatorname{Re}(\mathrm{d} \pi)$ and bpy $\left(\pi^{*}\right)$ orbitals which are weakly coupled. ${ }^{38}$ The spectrum of $\left[\mathrm{Re}(4 \mathrm{DHBP})(\mathrm{CO})_{3} \mathrm{Cl}\right]$ in $\mathrm{CH}_{3} \mathrm{CN}$ features the expected MLCT band at $355 \mathrm{~nm}$ which is blue-shifted relative to $\left[\mathrm{Re}(\mathrm{bpy})(\mathrm{CO})_{3} \mathrm{Cl}\right]$ $(384 \mathrm{~nm})$ in accord with the electron-donating substituents having stronger influence on the ligand $\pi^{*}$ orbitals than on $\operatorname{Re}(\mathrm{d} \pi)$ orbitals. ${ }^{38}$ Titration with $\mathrm{Bu}_{4} \mathrm{NOH}$ (Figure $2 \mathrm{~A}$ ) revealed two unique but similar $\mathrm{p} K_{\mathrm{a}} \mathrm{s}$ for ligand $-\mathrm{OH}$ groups. There is a single isosbestic point at $228 \mathrm{~nm}$ for $<0.6$ eq. $\mathrm{OH}^{-}$as the local $\lambda_{\max }$ shifted from 223 to $230 \mathrm{~nm}$. From 0.6 to 2 eq. base, the UV maximum shifted to $254 \mathrm{~nm}$ while the low energy band increased in intensity and blue shifts from $\lambda_{\max }=355$ to $340 \mathrm{~nm}$.

The absorption spectrum of $\left[\operatorname{Re}(6 \mathrm{DHBP})(\mathrm{CO})_{3} \mathrm{Cl}\right]$ (Figure $\left.2 \mathrm{~B}\right)$ exhibits a structured transition with $\lambda_{\max }=338 \mathrm{~nm}\left(\varepsilon=1.7 \times 10^{4}\right.$ $\mathrm{M}^{-1} \mathrm{~cm}^{-1}$ ) which is atypical of this family of compounds. According to time-dependent DFT calculations, this transition is intraligand $\left(\pi \rightarrow \pi^{*}\right)$ mixed with $\left(\mathrm{n}_{(\mathrm{OH})} \rightarrow \pi^{*}\right)$ (Table S5 and Figure S3) Weak, low energy MLCT or $(\mathrm{M}+\mathrm{Cl}) \mathrm{LCT}$ charge transfer transitions are calculated at 380,355 , and $337 \mathrm{~nm}$. Titration in $\mathrm{CH}_{3} \mathrm{CN}$ using $\mathrm{Et}_{3} \mathrm{~N}$ as the base revealed two $\mathrm{p} K_{\mathrm{a}} \mathrm{s}$ for ligand $-\mathrm{OH}$ groups. For $<1$ eq. $\mathrm{Et}_{3} \mathrm{~N}$, isosbestic points appeared at 242, 268, 286, and $356 \mathrm{~nm}$ while the $338 \mathrm{~nm}$ band decreased and the absorption from 375 to $450 \mathrm{~nm}$ increased. The red shifted absorption in the pyridinolate form is consistent with a higher energy HOMO. Above 1 eq. base, the intense band at $c a .400 \mathrm{~nm}$ continued to increase while the low energy tail decreased in absorbance. The titrations in $\mathrm{CH}_{3} \mathrm{CN}$ reveal two acid-base reactions despite the molecular symmetry. Similarly, two $\mathrm{p} K_{\mathrm{a}} \mathrm{s}$ were reported for $\left[\mathrm{Rh}(6 \mathrm{DHBP})(\mathrm{CO})_{2}\right]^{+} .{ }^{39}$

Emission of protonated and deprotonated species were examined briefly under the premise that flash-quench studies could be used to study reduced species. Both $\left[\mathrm{Re}(4 \mathrm{DHBP})(\mathrm{CO})_{3} \mathrm{Cl}\right]$ and $\left[\mathrm{Re}(6 \mathrm{DHBP})(\mathrm{CO})_{3} \mathrm{Cl}\right]$ exhibit the MLCT emission found in this family of complexes; however, reductive quenching was ineffective owing to the short lived excited states $(<10 \mathrm{~ns})$ and deprotonation of the complexes by most reductive quenchers.

Acid-base behavior in water was investigated for comparison to $\mathrm{p} K_{\mathrm{a}}$ values of related complexes (Figures $\mathrm{S} 4$ ). In $\mathrm{H}_{2} \mathrm{O} / 1 \%$ $\mathrm{CH}_{3} \mathrm{CN}$, the sigmoidal inflection point at $260 \mathrm{~nm}$ of an $\varepsilon$ vs. $\mathrm{pH}$ plot provides $\mathrm{p} K_{\mathrm{a}}=5.6$ for $\left[\operatorname{Re}(4 \mathrm{DHBP})(\mathrm{CO})_{3} \mathrm{Cl}\right]$ The $\mathrm{p} K_{\mathrm{a}}$ of $\left[\mathrm{Re}(6 \mathrm{DHBP})(\mathrm{CO})_{3} \mathrm{C}\right.$ is 4.5 as calculated from the sigmoidal fit of $\varepsilon$ at $378 \mathrm{~nm}$ vs. pH. A single spectroscopic transition for each compound indicates close or identical $\mathrm{p} K_{\mathrm{a}}$ values in $\mathrm{H}_{2} \mathrm{O}$. By definition, ${ }^{40}$ the $\mathrm{p} K_{\mathrm{a}}$ for a two-proton acid-base equilibrium with equal $\mathrm{p} K_{\mathrm{a}}$ is twice the $\mathrm{pH}$ at the inflection point; therefore, the measured $\mathrm{pH}$ values of the inflection point imply $\mathrm{p} K_{\mathrm{a}}$ of 11.2 and 9; however, owing to the non-intuitive nature of such $\mathrm{p} K_{\mathrm{a}}$ values, the average $\mathrm{p} K_{\mathrm{a}}$ is often reported at the inflection point. Our values are in the expected range of 4.4 to 7.3 reported for related $\mathrm{Co}(\mathrm{III}), \mathrm{Ir}(\mathrm{III})$, and $\mathrm{Ru}(\mathrm{II})$ with 4 - or $6 \mathrm{DHBP}$ ligands. ${ }^{41,27,28,4243}$

3.3. UV-vis Spectroelectrochemistry. Figure $2 \mathrm{C}$ and $2 \mathrm{D}$ present changes in absorption spectra upon electrochemical reduction. During reduction of $\left[\mathrm{Re}(4 \mathrm{DHBP})(\mathrm{CO})_{3} \mathrm{Cl}\right]$ (Figure $2 \mathrm{C}$ ) with $\mathrm{V}=$ $-1.2 \mathrm{~V}$ vs. $\mathrm{Ag} / \mathrm{AgCl}$ spectra exhibited a decrease in the $233 \mathrm{~nm}$ band and increases at 245 and $370 \mathrm{~nm}$ with several isosbestic points (black traces). Without changing the applied potential, isosbestic points at 209, 229, and 388 were lost (red traces) then isobestic points appeared at 214, 241, and $365 \mathrm{~nm}$ (blue traces). It was not possible to isolate $1 \mathrm{e}^{-}$reduced compounds even at potentials anodic of the first reduction by $\mathrm{CV}$ suggesting these species are unstable to disproportionation, or the first two 
reduction potentials are very similar. The experiment was repeated for $\left[\operatorname{Re}(6 \mathrm{DHBP})(\mathrm{CO})_{3} \mathrm{Cl}\right]$ (Figure 2D). Again, the final $2 \mathrm{e}^{-}$reduced species was formed at the onset of $\left[\mathrm{Re}(6 \mathrm{DHBP})(\mathrm{CO})_{3} \mathrm{Cl}\right]$ reduction at $-1.2 \mathrm{~V}$; however the spectrum of the $1 \mathrm{e}^{-}$reduced species can be isolated (red trace) as indicated by two sets of clear isosbestic points.

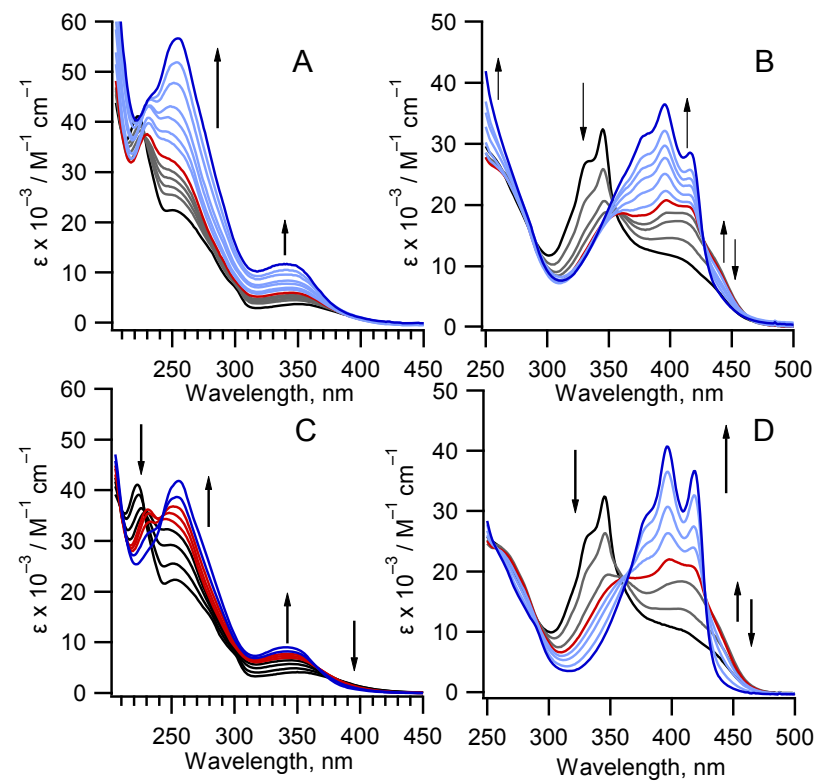

Figure 2. $A$ and $B$ : Acid/base titrations in $\mathrm{CH}_{3} \mathrm{CN}$ of $\left[\mathrm{Re}(4 \mathrm{DHBP})(\mathrm{CO})_{3} \mathrm{Cl}\right](\mathrm{A})$ using $\mathrm{Bu}_{4} \mathrm{NOH}$ with the black, red, and blue spectra corresponding to $0,0.6$, and 2 eq. $\mathrm{OH}^{-}$and $\left[\operatorname{Re}(6 \mathrm{DHBP})(\mathrm{CO})_{3} \mathrm{Cl}\right](\mathrm{B})$ using $\mathrm{Et}_{3} \mathrm{~N}$ as the base. The black, red, and blue spectra correspond to $0,1.5$, and 10 eq. $\mathrm{Et}_{3} \mathrm{~N}$. $C$ and $D$ : Spectroelectrochemical reduction of $\left[\operatorname{Re}(4 \mathrm{DHBP})(\mathrm{CO})_{3} \mathrm{Cl}\right](\mathrm{C})$ and $\left[\operatorname{Re}(6 \mathrm{DHBP})(\mathrm{CO})_{3} \mathrm{Cl}\right](\mathrm{D})$ at $-1.2 \mathrm{~V}$ vs. $\mathrm{Ag} / \mathrm{AgCl}$. In $\mathrm{C}$, black spectra indicate mixtures of $\left[\operatorname{Re}(4 \mathrm{DHBP})(\mathrm{CO})_{3} \mathrm{Cl}\right]$ and singly reduced species, blue spectra are due to mixtures of singly- and doubly-reduced species while red spectra are obtained with all three forms present. In $\mathrm{D}$, The black, red, and blue spectra are $\left[\operatorname{Re}(6 \mathrm{DHBP})(\mathrm{CO})_{3} \mathrm{Cl}\right]$ singly-reduced and doubly-reduced species, respectively.

Careful comparison of Figures 2A/C and 2B/D shows chemical deprotonation and electrochemical reduction produce complexes with strikingly similar electronic absorption spectra in agreement with NMR and IR data mentioned previously. In the following sections, cyclic voltammetry (CV) and spectroelectrochemical IR are used to further characterize these species. The $\mathrm{CV}$ behavior is unique among $\left[\operatorname{Re}(\alpha\right.$-diimine $\left.)(\mathrm{CO})_{3} \mathrm{Cl}\right]$ complexes, and IR experiments show that electrochemical reduction leads to reductive deprotonation of the ligand thus producing the same species obtained by chemical deprotonation. While counterintuitive, there is precedent for this phenomenon in $\left[\operatorname{Re}(\right.$ bpy $)(\mathrm{CO})_{3}($ imidazole $\left.)\right]$ in which the imidazole N-H bond is cleaved after $1 \mathrm{e}^{-}$reduction of the bpy. ${ }^{44}$

3.4. Cyclic Voltammetry of $\left[\operatorname{Re}(4 \mathrm{DHBP})(\mathrm{CO})_{3} \mathrm{Cl}\right]$ and $\left[\operatorname{Re}(6 \mathrm{DHBP})(\mathrm{CO})_{3} \mathrm{Cl}\right]$ under Argon. For reference, the $\mathrm{CVs}$ of $\left[\mathrm{Re}\left({ }^{t} \mathrm{Bu}_{2} \mathrm{bpy}\right)(\mathrm{CO})_{3} \mathrm{Cl}\right]$ are shown in Figure 3 (trace a) and S6 as an example of the known electrochemistry for $\left[\operatorname{Re}^{\mathrm{I}}(\alpha-\right.$ diimine $(\mathrm{CO})_{3} \mathrm{Cl}$ complexes. The $\mathrm{CV}$ is typical of an EEC mechanism (eq. i-iv) with chloride dissociation as the chemical step. Agreement between $\left[\operatorname{Re}\left({ }^{t} \mathrm{Bu}_{2} \mathrm{bpy}\right)(\mathrm{CO})_{3} \mathrm{Cl}\right]$ and data published for $\left[\mathrm{Re}(\mathrm{bpy})(\mathrm{CO})_{3} \mathrm{Cl}\right]$ in $\mathrm{DMF}$ including re-oxidation and subsequent reduction of newly formed species was found. ${ }^{45} \mathrm{In}$
Figure $3 \mathrm{a}$, the redox couple $\mathrm{I} / \mathrm{B}$ is $\left[\operatorname{Re}\left({ }^{t} \mathrm{Bu}_{2} \mathrm{bpy}\right)(\mathrm{CO})_{3}(\mathrm{DMF})\right]^{+/ 0}$, the II/A couple is $\left[\operatorname{Re}\left({ }^{t} \mathrm{Bu}_{2} \text { bpy }\right)(\mathrm{CO})_{3}(\mathrm{Cl})\right]^{0 /-}$, and peak III is reduction of $\left[\operatorname{Re}\left({ }^{t} \mathrm{Bu}_{2} \mathrm{bpy}\right)(\mathrm{CO})_{3}(\mathrm{Cl})\right]^{-}$which is followed by ligand dissociation (eq iii and iv).

\begin{tabular}{|c|c|c|}
\hline$\left[\operatorname{Re}\left({ }^{t} \mathrm{Bu}_{2}\right.\right.$ bpy $\left.)(\mathrm{CO})_{3} \mathrm{Cl}\right]$ & $+\mathrm{e}$ & {$\left[\operatorname{Re}\left({ }^{t} \mathrm{Bu}_{2} \mathrm{bpy}\right)(\mathrm{CO})_{3} \mathrm{Cl}\right]^{-}$} \\
\hline$\left[\operatorname{Re}\left({ }^{t} \mathrm{Bu}_{2} \mathrm{bpy}\right)(\mathrm{CO})_{3} \mathrm{Cl}\right]^{-}$ & $\stackrel{-\mathrm{Cl} \text {, slow }}{\longrightarrow}$ & {$\left[\operatorname{Re}\left({ }^{t} \mathrm{Bu}_{2} \mathrm{bpy}\right)(\mathrm{CO})_{3}\right]$} \\
\hline$\left[\operatorname{Re}\left({ }^{t} \mathrm{Bu}_{2} \mathrm{bpy}\right)(\mathrm{CO})_{3} \mathrm{Cl}\right]^{-}$ & $+e$ & {$\left[\operatorname{Re}\left({ }^{t} \mathrm{Bu}_{2} \mathrm{bpy}\right)(\mathrm{CO})_{3} \mathrm{Cl}\right]^{2-}$} \\
\hline$\left[\operatorname{Re}\left({ }^{t} \mathrm{Bu}_{2} \mathrm{bpy}\right)(\mathrm{CO})_{3} \mathrm{Cl}\right]^{2-}$ & $-\mathrm{Cl}$, fast & {$\left[\operatorname{Re}\left({ }^{t} \mathrm{Bu}_{2} \mathrm{bpy}\right)(\mathrm{CO})_{3}\right]^{-}$} \\
\hline
\end{tabular}

The reductive $\mathrm{CV}$ of $\left[\mathrm{Re}(4 \mathrm{DHBP})(\mathrm{CO})_{3} \mathrm{Cl}\right]$ (Figures 3 and $\mathrm{S} 7$ ) exhibits a three wave pattern $\left(E_{\mathrm{p}}{ }^{\mathrm{c}}=-1.56,-1.76\right.$, and $\left.-2.03 \mathrm{~V}\right)$ with each wave irreversible except for peak R1 above $0.75 \mathrm{~V} \mathrm{~s}^{-1}$. Peak I is diffusion controlled with $\mathrm{D}=2.3 \times 10^{-6} \mathrm{~cm}^{2} \mathrm{~s}^{-1}$ from a plot of $i_{p}^{c} v s v^{1 / 2}$ according to the Randles-Sevcik equation, ${ }^{46}$ and is reasonable in comparison to $2.65 \times 10^{-6} \mathrm{~cm}^{2} \mathrm{~s}^{-1}$ reported for iron meso-tetraphenylporphyrin in DMF. ${ }^{47}$ The ratio of current at peaks R2 and R3 depends on scan rate indicating competing reactions on the $\mathrm{CV}$ timescale (Figure S7). Bulk electrolysis cathodic of R3 consumed $2 \mathrm{e}^{-}$per molecule indicating peaks R2 and R3 comprise a one-electron, two-wave system.

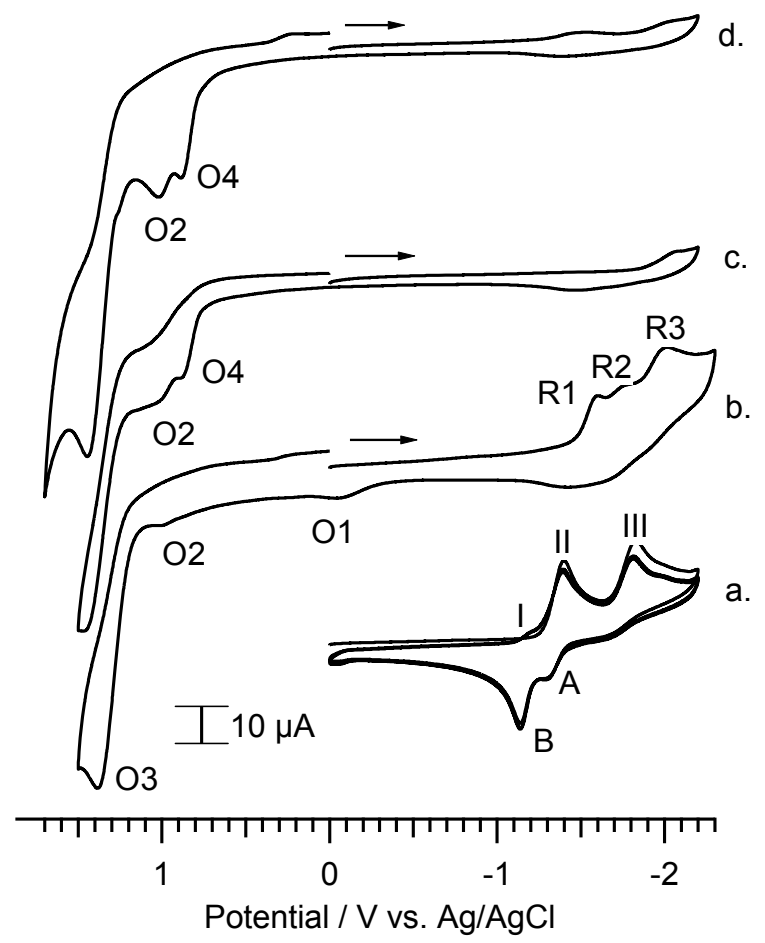

Figure 3. Multi-scan reductive cyclic voltammograms for 2.0 $\mathrm{mM}$ solutions of $\left[\operatorname{Re}\left({ }^{t} \mathrm{Bu}_{2} \mathrm{bpy}\right)(\mathrm{CO})_{3} \mathrm{Cl}\right]$ (trace a) and $\left[\operatorname{Re}(4 \mathrm{DHBP})(\mathrm{CO})_{3} \mathrm{Cl}\right]$ (trace b-d) and in DMF with $v=0.1 \mathrm{~V} \mathrm{~s}^{-1}$ In trace $\mathrm{c}$, the complex was reduced exhaustively by $2 \mathrm{e}^{-}$. The $\mathrm{CV}$ in trace $\mathrm{d}$ was recorded in the presence of 2 eq. $\mathrm{Bu}_{4} \mathrm{NOH}$.

The re-oxidation peak $\mathrm{O} 1$ at $E_{p}{ }^{a}=0 \mathrm{~V}$ is not the anodic counterpart of $\mathrm{R} 1$. Its appearance requires reduction beyond $\mathrm{R} 2$ (SI). The potential of $\mathrm{O} 1$ is similar to the $\mathrm{Re}-\mathrm{Re}$ dimer oxidation in acetonitrile ${ }^{45}$; however, no dimer was observed during SEC-IR experiments in this work (see below). Multi-scan reductive CVs inclusive of $\mathrm{O} 1$ show the system is chemically reversible but electrochemically irreversible (SI). No peaks of solvento complexes were observed. The potential of $\mathrm{O} 2$ at $+1 \mathrm{~V}$ is similar to the $2 \mathrm{Cl}^{-} / \mathrm{Cl}_{2}$ couple and is suggestive of $\mathrm{Cl}^{-}$dissociation after reduction and slow re-association at the $\mathrm{O} 1$ wave. Oxidation $\mathrm{O} 3$ at 
$1.38 \mathrm{~V}$ is a characteristic of $\left[\operatorname{Re}^{\mathrm{I}}(\alpha\right.$-diimine $\left.)(\mathrm{CO})_{3} \mathrm{Cl}\right]$ complexes, ${ }^{45}$ however, in this case $\mathrm{O} 3$ comprises $2 \mathrm{e}^{-} /$molecule as determined by comparison of it current to $\left[\operatorname{Re}\left({ }^{t} \mathrm{Bu} u_{2}\right.\right.$ bpy $\left.)(\mathrm{CO})_{3} \mathrm{Cl}\right]$.

A reductive $\mathrm{CV}$ after bulk electrolysis and consumption of $2 \mathrm{e}^{-} /$molecule (Figure $3 \mathrm{c}$ ) shows the absence of reductive waves, the presence of a new peak $\mathrm{O} 4$ at $0.87 \mathrm{~V}$, and larger current for $\mathrm{O} 2$. In trace $\mathbf{d}$, the $\mathrm{CV}$ was recorded in the presence of 2eq. $\mathrm{Bu}_{4} \mathrm{NOH}$ to deprotonate the ligand. The features are identical to trace c suggesting the same species are formed upon chemical deprotonation or electrochemical reduction.

The unusual reductive electrochemistry of $\left[\mathrm{Re}(4 \mathrm{DHBP})(\mathrm{CO})_{3} \mathrm{Cl}\right]$ relative to $\left[\mathrm{Re}\left({ }^{t} \mathrm{Bu} \mathrm{u}_{2} \mathrm{bpy}\right)(\mathrm{CO})_{3} \mathrm{Cl}\right]$ is clear by examination of Figures 3 and S6-S7. The increased electron donating ability of the $4,4^{\prime}-\mathrm{OH}$ groups relative to ${ }^{t} \mathrm{Bu}$ shifts the first reduction cathodically. The quasi-reversible nature of R1 and the scan-rate dependence on R2 and R3 currents suggest a process in which two products of $\mathrm{R} 1$ are reduced separately. The minimal mechanism to account for this behavior is competing EEC and ECE processes as shown in Scheme 1; however, as will be discussed subsequently, electrochemical reduction triggers reductive deprotonation of $1 \mathrm{e}^{-}$or $2 \mathrm{e}^{-}$reduced species. Furthermore, $\mathrm{Cl}^{-}$dissociation can occur from any reduced or deprotonated species. At minimum, we approximate the rate of consumption for species $\mathrm{B}$ as $k_{1}=8 \mathrm{~s}^{-1}$ by digital simulation of $\mathrm{R} 1$ according to an EC mechanism (Figures S8).

The $\mathrm{CV}$ of $\left[\mathrm{Re}(6 \mathrm{DHBP})(\mathrm{CO})_{3} \mathrm{Cl}\right]$ (Figure S9) exhibits features similar to $\left[\operatorname{Re}(4 \mathrm{DHBP})(\mathrm{CO})_{3} \mathrm{Cl}\right]$ and the results are discussed in the SI.

Scheme 1. Minimal mechanism for $\left[\operatorname{Re}(4 \mathrm{DHBP})(\mathrm{CO})_{3} \mathrm{Cl}\right]$ reduction.

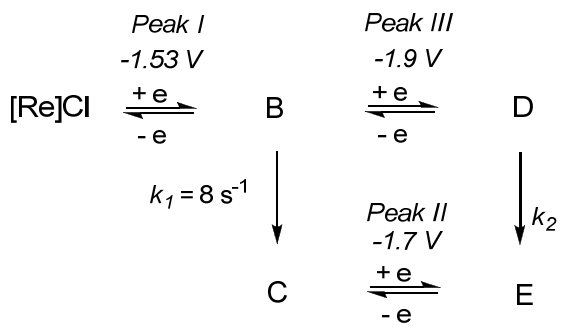

3.5. Spectroelectrochemical IR The sensitivity of $v(\mathrm{CO})$ to oxidation state and coordination environment provides a handle for investigation by SEC-IR..$^{9,48,10}$ The $\left[\operatorname{Re}(4 \mathrm{DHBP})(\mathrm{CO})_{3} \mathrm{Cl}\right]$ was studied in DMF and in $\mathrm{CH}_{3} \mathrm{CN}$ since the sampling window is wider in the latter solvent. The results are the same in both solvents. The first reduction (Figure 4a) leads to a decrease in the CO stretches at 2019, 1911, and 1893 and the weak band at 1627 $\mathrm{cm}^{-1}$ and growth of a new species with $v(\mathrm{CO}) 2012,1900$, and $1881 \mathrm{~cm}^{-1}$ (blue spectrum). This species disappears during the second reduction and the final species exhibits $v(\mathrm{CO}) 2002,1886$, and 1865 , an intense absorption at 1605 and a weak band at 1532 $\mathrm{cm}^{-1}$ (red trace). The spectral changes were reversed upon reoxidation (4b).

Chemical deprotonation with two equivalents $\mathrm{Bu}_{4} \mathrm{NOH}$ yielded a species for which the IR spectrum is identical to the doubly reduced species (Figure 4c, red). Spectral changes during oxidation of this species mirrored those observed in set b with the exception of a new $\mathrm{CO}$ stretch at $2033 \mathrm{~cm}^{-1}$ and a poorly resolved shoulder at $1931 \mathrm{~cm}^{-1}$. The high energy stretch is consistent with solvent coordination as in $\left[\operatorname{Re}(4 \mathrm{DHBP})(\mathrm{CO})_{3}\left(\mathrm{CH}_{3} \mathrm{CN}\right)\right]^{+}$ according to literature for related complexes. ${ }^{10}$

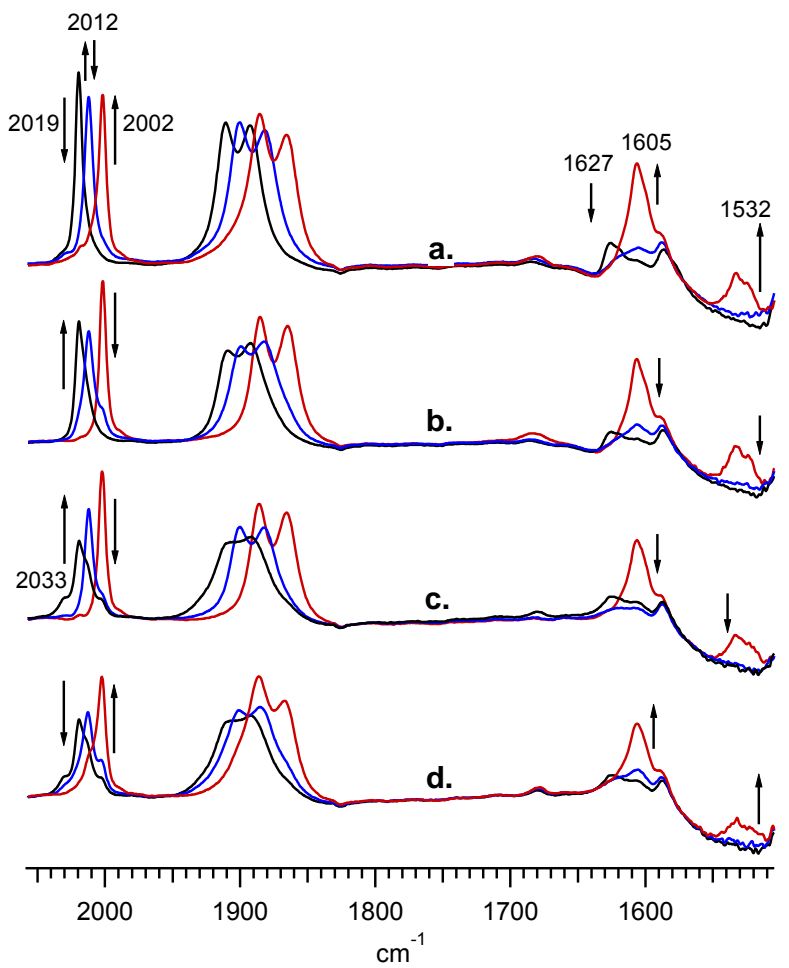

Figure 4. Solution IR of $\left[\operatorname{Re}(4 \mathrm{DHBP})(\mathrm{CO})_{3} \mathrm{Cl}\right]$ in $\mathrm{CH}_{3} \mathrm{CN}$ during electrochemical reduction (a) and re-oxidation (b), upon oxidation (c) and reduction (d) of the chemically deprotonated species.

The SEC-IR experiments were repeated on $\left[\operatorname{Re}(6 \mathrm{DHBP})(\mathrm{CO})_{3} \mathrm{Cl}\right]$. In $\mathrm{CH}_{3} \mathrm{CN}$, the IR spectrum shows $\mathrm{CO}$ stretches at 2022,1915, and $1887 \mathrm{~cm}^{-1}$ (Figure S11). The species formed after single reduction or deprotonation with 1eq. base is insoluble in $\mathrm{CH}_{3} \mathrm{CN}$; however, the doubly reduced species is soluble with IR absorptions at 1994, 1879, 1843 (CO stretches), 1614 , and $1512 \mathrm{~cm}^{-1}$. Re-oxidation of the electrochemically generated species is reversible but also produces new $v(\mathrm{CO}) 2032$ and $1934 \mathrm{~cm}^{-1}$ attributed to $\left[\operatorname{Re}(6 \mathrm{DHBP})(\mathrm{CO})_{3}\left(\mathrm{CH}_{3} \mathrm{CN}\right)\right]$. The spectrum of the chemically deprotonated complex is identical to the doubly reduced species and its oxidation also yields $\left[\mathrm{Re}(6 \mathrm{DHBP})(\mathrm{CO})_{3} \mathrm{Cl}\right]$ and $\left[\mathrm{Re}(6 \mathrm{DHBP})(\mathrm{CO})_{3}\left(\mathrm{CH}_{3} \mathrm{CN}\right)\right]$.

All species associated with $\left[\mathrm{Re}(6 \mathrm{DHBP})(\mathrm{CO})_{3} \mathrm{Cl}\right]$ are soluble in $\mathrm{DMF}$ and electrochemical reduction is shown in Figure 5a. CO stretches of $\left[\operatorname{Re}(6 \mathrm{DHBP})(\mathrm{CO})_{3} \mathrm{Cl}\right]$ at 2016,1910 , and $1879 \mathrm{~cm}^{-1}$ disappear during the first reduction as peaks at 2002, 1893, and $1858 \mathrm{~cm}^{-1}$ appear (blue spectrum). Further reduction produces a species with $v(\mathrm{CO}) 1990,1877$, and $1840 \mathrm{~cm}^{-1}$ (red spectrum). As in $\mathrm{CH}_{3} \mathrm{CN}$, the process is reversed by applying an oxidizing potential. The experiment was repeated in THF, DMSO, and pyridine and identical $\mathrm{CO}$ stretches were obtained proving that the $1 \mathrm{e}^{-}$and $2 \mathrm{e}^{-}$reduced species do not coordinate solvent. In Figure $5 \mathrm{~b},\left[\mathrm{Re}(6 \mathrm{DHBP})(\mathrm{CO})_{3} \mathrm{Cl}\right]$ was partially deprotonated with $1 \mathrm{eq}$ $\mathrm{Bu}_{4} \mathrm{NOH}$ (bold, black spectrum). This sample was then reduced (red spectrum) and subsequently re-oxidized (blue to thin black spectra). Spectra throughout this sequence were identical to those obtained during electrolysis in the absence of base. 


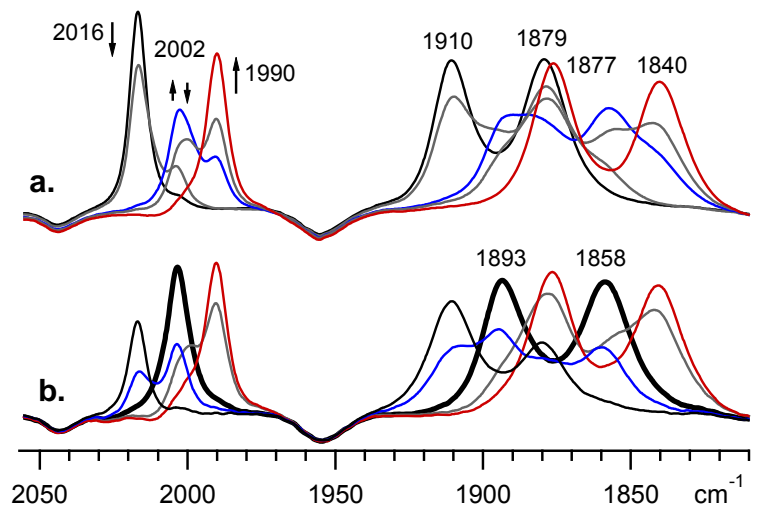

Figure 5. Solution IR of $\left[\operatorname{Re}(6 \mathrm{DHBP})(\mathrm{CO})_{3} \mathrm{Cl}\right]$ in $\mathrm{DMF}$ during electrochemical reduction (a) and a partial deprotonation, reduction, re-oxidation sequence (b). In (b), the initial singly deprotonated species (bold black spectrum) was electrochemically reduced (red spectrum) then re-oxidized to the thin black spectrum.

SEC-IR data for $\left[\mathrm{Re}(\mathrm{bpy})(\mathrm{CO})_{3} \mathrm{Cl}\right]$ in $\mathrm{CH}_{3} \mathrm{CN}$ provides benchmarks for typical behavior during reduction (Table 2). ${ }^{10}$ One-electron reduction yields $\left[\mathrm{Re}(\mathrm{bpy})(\mathrm{CO})_{3} \mathrm{Cl}\right]^{-}$with a bipyridine-localized radical. Exchange of $\mathrm{Cl}^{-}$for solvent produced $\left[\operatorname{Re}(\right.$ bpy $\left.)(\mathrm{CO})_{3}\left(\mathrm{CH}_{3} \mathrm{CN}\right)\right]$ as indicated by a blue shift in $v(\mathrm{CO})$. Further reduction produced the five-coordinate anion $\left[\operatorname{Re}(\text { bpy })(\mathrm{CO})_{3}\right]^{-}$with $v(\mathrm{CO})=1947$ and $1843 \mathrm{~cm}^{-1}$. We preformed SEC-IR measurements on $\left[\operatorname{Re}\left({ }^{t} \mathrm{Bu}_{2}\right.\right.$ bpy $\left.)(\mathrm{CO})_{3} \mathrm{Cl}\right]$ in DMF for direct comparison to the new DHBP complexes (Figure $\mathrm{S} 12$ and Table 2). The $1 \mathrm{e}^{-}$reduced $\left[\operatorname{Re}\left({ }^{t} \mathrm{Bu}_{2} \mathrm{bpy}\right)(\mathrm{CO})_{3} \mathrm{Cl}\right]^{-}$ dissociates $\mathrm{Cl}^{-}$but does not bind solvent as indicated by a redshift in $v(\mathrm{CO})$. Data for $\left[\mathrm{Re}\left(\mathrm{OMe}_{2}\right.\right.$ bpy $\left.)(\mathrm{CO})_{3} \mathrm{Cl}\right]$ are identical to $\left[\mathrm{Re}\left({ }^{t} \mathrm{Bu}_{2}\right.\right.$ bpy $\left.)(\mathrm{CO})_{3} \mathrm{Cl}\right]$.

Table 2. Select $v(\mathrm{CO})$ data for $\left[\mathrm{Re}(4 \mathrm{DHBP})(\mathrm{CO})_{3} \mathrm{Cl}\right]$, $\left[\mathrm{Re}(6 \mathrm{DHBP})(\mathrm{CO})_{3} \mathrm{Cl}\right]$, and related complexes.

\begin{tabular}{|c|c|c|}
\hline Complex ${ }^{\mathrm{a}}$ & $v(\mathrm{CO}) / \mathrm{cm}^{-1}$ & solvent \\
\hline$\left[\mathrm{Re}(4 \mathrm{DHBP})(\mathrm{CO})_{3} \mathrm{Cl}\right]$ & $2019,1911,1893$ & $\mathrm{CH}_{3} \mathrm{CN}$ \\
\hline$\left[\operatorname{Re}\left(4 \mathrm{DHBP}-\mathrm{H}^{+}\right)(\mathrm{CO})_{3} \mathrm{Cl}\right]^{-b}$ & $2012,1900,1881$ & $\mathrm{CH}_{3} \mathrm{CN}$ \\
\hline$\left[\operatorname{Re}\left(4 \mathrm{DHBP}-2 \mathrm{H}^{+}\right)(\mathrm{CO})_{3}\right]^{-c}$ & $2002,1886,1865$ & $\mathrm{CH}_{3} \mathrm{CN}$ \\
\hline$\left[\operatorname{Re}(6 \mathrm{DHBP})(\mathrm{CO})_{3} \mathrm{Cl}\right]^{b}$ & $2016,1910,1879$ & DMF \\
\hline$\left[\operatorname{Re}\left(6 \mathrm{DHBP}-1 \mathrm{H}^{+}\right)(\mathrm{CO})_{3} \mathrm{Cl}\right]^{-b}$ & $2002,1893,1858$ & DMF \\
\hline$\left[\operatorname{Re}\left(6 \mathrm{DHBP}-2 \mathrm{H}^{+}\right)(\mathrm{CO})_{3}\right]^{-c}$ & $1990,1877,1840$ & DMF \\
\hline$\left[\mathrm{Re}(\mathrm{bpy})(\mathrm{CO})_{3} \mathrm{Cl}\right]^{d}$ & $2020,1914,1897$ & $\mathrm{CH}_{3} \mathrm{CN}$ \\
\hline$\left[\operatorname{Re}(\mathrm{bpy})(\mathrm{CO})_{3}(\mathrm{Cl})\right]^{-d}$ & $1998,1885,1867$ & $\mathrm{CH}_{3} \mathrm{CN}$ \\
\hline$\left[\operatorname{Re}(\mathrm{bpy})(\mathrm{CO})_{3}\left(\mathrm{CH}_{3} \mathrm{CN}\right)\right]^{d}$ & 2011,1895 & $\mathrm{CH}_{3} \mathrm{CN}$ \\
\hline$\left[\operatorname{Re}(\text { bpy })(\mathrm{CO})_{3}\right]^{-d}$ & 1947,1843 & $\mathrm{CH}_{3} \mathrm{CN}$ \\
\hline$\left[\operatorname{Re}\left({ }^{t} \mathrm{Bu}_{2} \mathrm{bpy}\right)(\mathrm{CO})_{3} \mathrm{Cl}\right]$ & $2018,1913,1890$ & DMF \\
\hline$\left[\operatorname{Re}\left({ }^{t} \mathrm{Bu}_{2} \mathrm{bpy}\right)(\mathrm{CO})_{3}(\mathrm{Cl})\right]^{-}$ & $1992,1878,1860$ & DMF \\
\hline$\left[\operatorname{Re}\left({ }^{t} \mathrm{Bu}_{2} \mathrm{bpy}\right)(\mathrm{CO})_{3}\right]$ & 1988,1865 & DMF \\
\hline$\left[\operatorname{Re}\left({ }^{t} \mathrm{Bu}_{2} \mathrm{bpy}\right)(\mathrm{CO})_{3}\right]^{-}$ & 1934,1832 & DMF \\
\hline
\end{tabular}

${ }^{a}$ This work unless otherwise noted. ${ }^{b}$ Mono-deprotonated complexes with presumed $\mathrm{Cl}^{-}$ligand. ${ }^{c}$ Doubly-deprotonated complexes. ${ }^{d}$ Reference 10.

Comparison of SEC-IR data to the spectra of chemically deprotonated species shows that identical substances are produced in each process. The high energy $\mathrm{CO}$ stretches of doubly reduced species are clearly different from the expected five-coordinate anion exemplified by $\left[\operatorname{Re}\left({ }^{t} \mathrm{Bu}_{2} \mathrm{bpy}\right)(\mathrm{CO})_{3}\right]^{-}$. The electrochemical deprotonation can be related to $\left[\operatorname{Re}(b p y)(\operatorname{Im}-\mathrm{H})(\mathrm{CO})_{3}\right]^{+}(\mathrm{Im}-\mathrm{H}=$ imidazole) in which an initial $1 \mathrm{e}^{-}$reduction at $-1.64 \mathrm{~V}^{\mathrm{vs}}$. $\mathrm{Fc}^{+/ 0}$ to $\left[\operatorname{Re}\left(\right.\right.$ bpy $\left.\left.^{-}\right)(\mathrm{Im}-\mathrm{H})(\mathrm{CO})_{3}\right]$ is followed by electron transfer and cleavage of the imidazole $\mathrm{NH}$ bond yielding $\left[\operatorname{Re}(\right.$ bpy $\left.)\left(\mathrm{Im}^{-}\right)(\mathrm{CO})_{3}\right]$. The first reduction is reversible by $\mathrm{CV}$ indicating a slow electron transfer/ $\mathrm{NH}$ bond cleavage step. This species is then reduced again at bpy at potentials $190 \mathrm{mV}$ more negative than the first reduction. ${ }^{44}$ In the case of DHBP complexes, the first reduction is quasi-reversible at elevated scan rates and two candidates for the chemical step are $\mathrm{OH}$ bond cleavage and $\mathrm{Cl}^{-}$dissociation. The $\Delta E$ of $\sim 200 \mathrm{mV}$ between the first and second reduction waves (R1 and R2) is analogous to the observed redox potentials in $\left[\operatorname{Re}(\mathrm{bpy})(\mathrm{Im}-\mathrm{H})(\mathrm{CO})_{3}\right]^{+}$and $\left[\operatorname{Re}(\right.$ bpy $\left.)\left(\mathrm{Im}^{-}\right)(\mathrm{CO})_{3}\right]$.

3.6. Calculated IR Spectra. IR and CV experiments demonstrate reductive deprotonation of DHBP complexes and $\mathrm{CV}$ data show loss $\mathrm{Cl}^{-}$; however, the point at which $\mathrm{Cl}^{-}$is lost (after single or double deprotonation) is unclear. IR spectra are unchanged in a variety of solvents negating solvent coordination to deprotonated species. DFT calculations were performed to investigate the coordination environment of Re and the nature of IR bands near 1530 and $1605 \mathrm{~cm}^{-1}$.

Calculated IR spectra for species derived from mono- and double deprotonation reactions are shown in Figures S13 and S14. The $v(\mathrm{CO})$ agree well with experimental data. Experimental $\mathrm{CO}$ stretching frequencies are shifted to lower energy upon monodeprotonation to $\left[\operatorname{Re}\left(4 \mathrm{DHBP}-1 \mathrm{H}^{+}\right)(\mathrm{CO})_{3}(\mathrm{Cl})\right]^{-}$, while calculated values for the solvent complex $\left[\operatorname{Re}\left(4 \mathrm{DHBP}-1 \mathrm{H}^{+}\right)(\mathrm{CO})_{3}(\mathrm{DMF})\right]$ are unchanged from $\left[\operatorname{Re}(4 \mathrm{DHBP})(\mathrm{CO})_{3}(\mathrm{Cl})\right]$ and stretching frequencies of the five-coordinate $\left[\operatorname{Re}\left(4 \mathrm{DHBP}-1 \mathrm{H}^{+}\right)(\mathrm{CO})_{3}\right]$ are shifted to higher energy. Energetically, loss of $\mathrm{Cl}^{-}$from the singly deprotonated species is uphill by $2.7 \mathrm{kcal} \mathrm{mol}^{-1}$. The calculated $\mathrm{CO}$ stretches for doubly deprotonated $\left[\mathrm{Re}\left(4 \mathrm{DHBP}-2 \mathrm{H}^{+}\right)(\mathrm{CO})_{3}\right]^{-}$ are slightly blue shifted; however this species is the best candidate given $\mathrm{CV}$ and SEC-IR data.

Features from 1500 to $1630 \mathrm{~cm}^{-1}$ are well-reproduced by the calculations. For $\left[\mathrm{Re}(4 \mathrm{DHBP})(\mathrm{CO})_{3} \mathrm{Cl}\right]$, three bipyridine stretches contribute to the peaks at 1620,1614 , and $1568 \mathrm{~cm}^{-1}$. In the singly deprotonated species, one ring stretching mode shifts to $1594 \mathrm{~cm}^{-1}$. In the doubly deprotonated species, the asymmetric and symmetric ring stretches are found at 1602 and $1590 \mathrm{~cm}^{-1}$ corresponding to the strong absorption at $1609 \mathrm{~cm}^{-1}$ in Figure 4. The broad absorption of the doubly deprotonated species near $1535 \mathrm{~cm}^{-1}$ in Figure 4 appears at 1507 in the calculated spectrum and is attributed to two stretching modes of almost pure $\mathrm{C}=\mathrm{O}$ character. Similarly for $\left[\mathrm{Re}(6 \mathrm{DHBP})(\mathrm{CO})_{3} \mathrm{Cl}\right]$, ring stretches are calculated at 1603,1590 , and $1508 \mathrm{~cm}^{-1}$. Upon deprotonation, these modes decrease in intensity and strong $\mathrm{CO}$ stretching modes appear at 1510 and $1490 \mathrm{~cm}^{-1}$. Experimentally, the absorption at $1512 \mathrm{~cm}^{-1}$ (Figure $\mathrm{S} 11$ ) is assigned as the $\mathrm{C}=\mathrm{O}$ stretching mode.

\subsection{Possible Mechanism of Reductive Deprotonation.}

Calculations were carried out for the two-electron reduction of $\left[\operatorname{Re}(4 \mathrm{DHBP})(\mathrm{CO})_{3}(\mathrm{DMF})\right]^{+}$assuming that the solvent molecule is dissociated in the process. As shown in Table S6, the standard free energy of the resulting $\left[\operatorname{Re}(4 \mathrm{DHBP})(\mathrm{CO})_{3}\right]^{-}$species was predicted to be $2.34 \mathrm{eV}$ vs. NHE above the starting complex. Protonation of the $\mathrm{C}$ atoms at the 5- and 5'-positions of the ligand anion $\left(4 \mathrm{DHBP}^{2-}\right)$, resulting in its partial dearomatization to form the $\left[\operatorname{Re}\left(4 \mathrm{DHBP}+2 \mathrm{H}^{+}\right)(\mathrm{CO})_{3}\right]^{+}$intermediate, was predicted to be exoergic $(-0.97 \mathrm{eV})$. This intermediate was further predicted to be capable of eliminating two protons and an $\mathrm{H}_{2}$ molecule in an 
exoergic reaction $(-0.69 \mathrm{eV})$ to form $\left[\mathrm{Re}\left(4 \mathrm{DHBP}-2 \mathrm{H}^{+}\right)(\mathrm{CO})_{3}\right]^{-}$, the doubly deprotonated product of the starting species. The freeenergy profile for this pathway is shown in Figure S15.

Similar calculations were carried out for the one-electron reduction of $\left[\operatorname{Re}(4 \mathrm{DHBP})(\mathrm{CO})_{3}(\mathrm{DMF})\right]^{+}$assuming that the solvent molecule remains coordinated to the metal center throughout the pathway. The reduced $\left[\operatorname{Re}(4 \mathrm{DHBP})(\mathrm{CO})_{3}(\mathrm{DMF})\right]$ was predicted to lie $1.39 \mathrm{eV}$ vs. NHE above the starting species (Table S7). Protonation of either $\mathrm{C}$ atom at the 5- or 5'-position resulted in the partially dearomatized $\left[\mathrm{Re}\left(4 \mathrm{DHBP}+\mathrm{H}^{+}\right)(\mathrm{CO})_{3}(\mathrm{DMF})\right]^{+}$intermediate in an exoergic reaction $(-0.51 \mathrm{eV})$. Because the production of $\mathrm{H}_{2}$ requires two electrons, and this is only a singly reduced species, a possible route to the singly deprotonated product of the starting complex is the disproportionation of this reduced and protonated intermediate,

$$
\begin{aligned}
& 2\left[\mathrm{Re}\left(4 \mathrm{DHBP}+\mathrm{H}^{+}\right)(\mathrm{CO})_{3}(\mathrm{DMF})\right]^{+} \rightarrow \\
& \quad 2\left[\operatorname{Re}\left(4 \mathrm{DHBP}-\mathrm{H}^{+}\right)(\mathrm{CO})_{3}(\mathrm{DMF})\right]^{0}+\mathrm{H}_{2}+2 \mathrm{H}^{+} .
\end{aligned}
$$

The elimination of $1 / 2 \mathrm{H}_{2}$ and $\mathrm{H}^{+}$from one molecule of $\left[\mathrm{Re}\left(4 \mathrm{DHBP}+\mathrm{H}^{+}\right)(\mathrm{CO})_{3}(\mathrm{DMF})\right]^{+}$(i.e., half the disproportionation reaction) to form $\left[\operatorname{Re}\left(4 \mathrm{DHBP}-\mathrm{H}^{+}\right)(\mathrm{CO})_{3}(\mathrm{DMF})\right]^{0}$ was also predicted to be exoergic $(-0.12 \mathrm{eV})$, and the free-energy profile of this pathway is shown in Figure S10. These results indicate that the two- and one-electron reduction of $\left[\operatorname{Re}(4 \mathrm{DHBP})(\mathrm{CO})_{3}(\mathrm{DMF})\right]^{+}$leading to the formation of its doubly and singly deprotonated species, respectively, is energetically feasible, and provide a plausible explanation for the experimental results presented above.

To verify the production of $\mathrm{H}_{2}$, bulk electrolysis experiments were carried out in a sealed vessel. After two-electron reduction of $\left[\operatorname{Re}(4 \mathrm{DHBP})(\mathrm{CO})_{3}(\mathrm{Cl})\right]$ or $\left[\operatorname{Re}(6 \mathrm{DHBP})(\mathrm{CO})_{3}(\mathrm{Cl})\right]$, approximately 0.1 eq. $\mathrm{H}_{2}$ was detected in the headspace. While not quantitative, zero $\mathrm{H}_{2}$ was detected when the experiment was repeated in the absence of Re complex

3.7. Cyclic Voltammetry of $\left[\operatorname{Re}(4 \mathrm{DHBP})(\mathrm{CO})_{3} \mathrm{Cl}\right]$ and $\left[\operatorname{Re}(6 \mathrm{DHBP})(\mathrm{CO})_{3} \mathrm{Cl}\right]$ under $\mathrm{CO}_{2}$ Atmosphere. In $\mathrm{CO}_{2}$ saturated $\mathrm{DMF},\left[\operatorname{Re}(4 \mathrm{DHBP})(\mathrm{CO})_{3} \mathrm{Cl}\right]$ exhibits a catalytic current coincident with peak II at $-1.65 \mathrm{~V}$ and an increase in slope at $1.85 \mathrm{~V}$ (Figure 6). Current increases to a maximum at $-2.4 \mathrm{~V}$. The current enhancement, $i_{c} / i_{\mathrm{p}}$, where $i_{c}$ and $i_{\mathrm{p}}$ are the peak current in the presence of $\mathrm{CO}_{2}$ and the current at $-1.85 \mathrm{~V}$ in the absence of $\mathrm{CO}_{2}, \quad$ is 12.3. Under identical conditions, $i_{c} / i_{\mathrm{p}}$ for $\left[\operatorname{Re}\left({ }^{t} \mathrm{Bu}_{2} \mathrm{bpy}\right)(\mathrm{CO})_{3} \mathrm{Cl}\right]$ is 4.7 at $-2.05 \mathrm{~V}$. With $5 \%$ water added, catalytic current is attenuated in contrast to the effects of water on catalysis using $\left[\mathrm{Re}(\mathrm{bpy})(\mathrm{CO})_{3} \mathrm{Cl}\right]$ and of weak acids on related complexes. ${ }^{8,49,50}$ In the presence of 2 eq. $\mathrm{OH}^{-}$and $\mathrm{CO}_{2}$, the catalytic waveform is similar but shifted positive by $c a$. $0.05 \mathrm{~V}$. It is noteworthy to recall the absence of reductive waves for the deprotonated complex and the formation of $[\operatorname{Re}(4 \mathrm{DHBP}-$ $\left.\left.2 \mathrm{H}^{+}\right)(\mathrm{CO})_{3}\right]^{-}$during electrolysis. The appearance of a catalytic current under $\mathrm{CO}_{2}$ indicates further reduction of the Re center in $\left[\operatorname{Re}\left(4 \mathrm{DHBP}-2 \mathrm{H}^{+}\right)(\mathrm{CO})_{3}\right]^{-}$or interaction of $[\mathrm{Re}(4 \mathrm{DHBP}-$ $\left.\left.2 \mathrm{H}^{+}\right)(\mathrm{CO})_{3}\right]^{-}$with $\mathrm{CO}_{2}$ followed by reduction. It is not possible to distinguish between pathways in the absence of an observable third reduction wave. DFT calculations did not yield a stationary state for the $\left[\operatorname{Re}\left(4 \mathrm{DHBP}-2 \mathrm{H}^{+}\right)(\mathrm{CO})_{3}\left(\mathrm{CO}_{2}\right)\right]^{-}$, but a stable structure for $\left[\operatorname{Re}\left(4 \mathrm{DHBP}-2 \mathrm{H}^{+}\right)(\mathrm{CO})_{3}\left(\mathrm{CO}_{2}\right)\right]^{2-}$ was reached. Ishitani and coworkers have demonstrated $\mathrm{CO}_{2}$ capture in the form of an organic carbonate in the $\operatorname{Re}(\mathrm{I})$ oxidation state. ${ }^{51}$ In the current work, we did not examine an exhaustive set of possibilities. Assessment of the data in relation to the $\mathrm{CO}_{2}$ chemistry of reduced quinones that capture $\mathrm{CO}_{2}$ but are not catalytic clarifies reactivity at the Re center as opposed to deprotonated ligands. ${ }^{52-54}$
The appearance of two slopes in the catalytic $\mathrm{CO}_{2}$ reduction wave using $\left[\operatorname{Re}(4 \mathrm{DHBP})(\mathrm{CO})_{3} \mathrm{Cl}\right]$ is explained by the two pathways for formation of $\left[\mathrm{Re}\left(4 \mathrm{DHBP}-2 \mathrm{H}^{+}\right)(\mathrm{CO})_{3}\left(\mathrm{CO}_{2}\right)\right]^{-}$on the $\mathrm{CV}$ timescale (Scheme 1, species E).
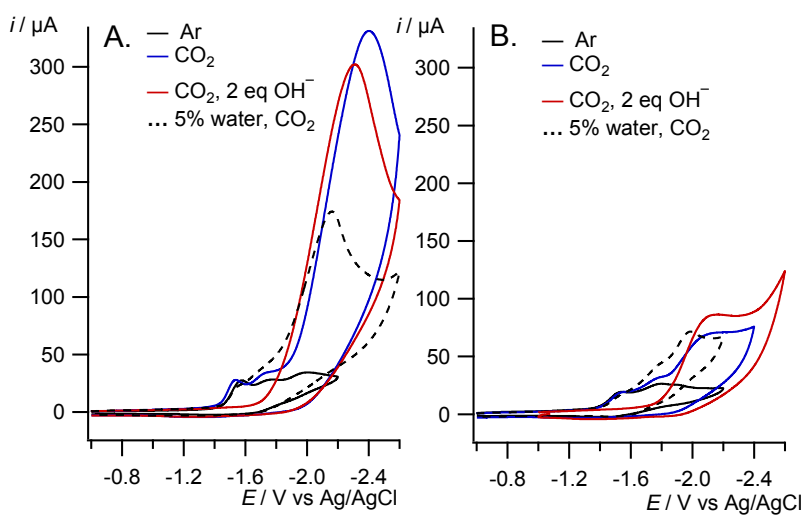

Figure 6. Cyclic voltammograms of $2.0 \mathrm{mM}$ $\left[\mathrm{Re}(4 \mathrm{DHBP})(\mathrm{CO})_{3} \mathrm{Cl}\right](\mathrm{A})$ and $\left[\mathrm{Re}(6 \mathrm{DHBP})(\mathrm{CO})_{3} \mathrm{Cl}\right](\mathrm{B})$ in $\mathrm{DMF}$ under $\mathrm{Ar}$ and $\mathrm{CO}_{2}$ in the absence (blue) or presence of 2 eq. $\mathrm{Bu}_{4} \mathrm{NOH}$ (red) or with $5 \% \mathrm{H}_{2} \mathrm{O}$ (black dashes). $v=0.1 \mathrm{~V} \mathrm{~s}^{-1}$.

The current response in the presence of $\mathrm{CO}_{2}$ does not permit straightforward calculation of catalytic rate constants. A simplified $\mathrm{EC}_{\mathrm{cat}}$ mechanism ${ }^{55}$ does not apply owing to the shallow slope of the catalytic wave and absence of a plateau current. A plot of limiting current vs. $\left[\mathrm{CO}_{2}\right]^{1 / 2}$ is linear confirming first-order dependence on $\left[\mathrm{CO}_{2}\right]$, but the slope of the catalytic wave also decreases dramatically at lower $\left[\mathrm{CO}_{2}\right]$. A foot-of-the-wave analysis $^{47}$ is not appropriate owing to the bimodal catalytic wave and shallow slope which deviates from ideal behavior. Furthermore, $E^{0}$ for the catalytic couple which is reduction of $\left[\mathrm{Re}\left(4 \mathrm{DHBP}-2 \mathrm{H}^{+}\right)(\mathrm{CO})_{3}\right]^{-}$or its $\mathrm{CO}_{2}$ adduct was not observable. Although rates cannot be compared directly, the current density by $\mathrm{CV}$ is nearly identical for $\left[\operatorname{Re}(4 \mathrm{DHBP})(\mathrm{CO})_{3} \mathrm{Cl}\right]$ and $\left[\mathrm{Re}\left({ }^{t} \mathrm{Bu}_{2} \mathrm{bpy}\right)(\mathrm{CO})_{3} \mathrm{Cl}\right]$ meaning the overpotential for catalysis is not greatly increased for the $-\mathrm{OH}$ substituted complex.

In $\mathrm{CO}_{2}$ saturated $\mathrm{DMF}$, the $\mathrm{CV}$ of $\left[\mathrm{Re}(6 \mathrm{DHBP})(\mathrm{CO})_{3} \mathrm{Cl}\right]$ exhibits increased current with onset at $-1.6 \mathrm{~V}$ and a plateau at 2.1 V (Figure $8 \mathrm{~B}$ blue trace). The current enhancement at $-2 \mathrm{~V}$ is 2.7. In the presence of $5 \%$ water, the current was unchanged but the overpotential decreased by $0.13 \mathrm{~V}$. A chemically deprotonated sample showed a similar current under $\mathrm{CO}_{2}$; however, this wave is largely independent of $\left[\mathrm{CO}_{2}\right]$ (Figure $\mathrm{S} 16$ ) and thus is not catalytic in nature.

\subsection{Bulk Electrolysis of $\left[\operatorname{Re}(4 \mathrm{DHBP})(\mathrm{CO})_{3} \mathrm{Cl}\right]$ and $\left[\operatorname{Re}(6 \mathrm{DHBP})(\mathrm{CO})_{3} \mathrm{Cl}\right]$ under $\mathbf{C O}_{2}$. The $\mathrm{CVs}$ of} $\left[\mathrm{Re}(4 \mathrm{DHBP})(\mathrm{CO})_{3} \mathrm{Cl}\right]$ (catalytic) and $\left[\mathrm{Re}(6 \mathrm{DHBP})(\mathrm{CO})_{3} \mathrm{Cl}\right]$ (noncatalytic) suggest reduction of $\mathrm{CO}_{2}$. Bulk electrolysis experiments were carried out for $1 \mathrm{~h}$ with an applied potential of $-2 \mathrm{~V}$ vs. $\mathrm{Ag} / \mathrm{AgCl}$ for product analysis. Select electrolysis data are summarized in Table 3 . In dry DMF, the $\left[\operatorname{Re}(4 \mathrm{DHBP})(\mathrm{CO})_{3} \mathrm{Cl}\right]$ and $\left[\mathrm{Re}(6 \mathrm{DHBP}) \mathrm{CO}_{3} \mathrm{Cl}\right]$ perform poorly compared to $\left[\mathrm{Re}\left({ }^{t} \mathrm{Bu}_{2}\right.\right.$ bpy $\left.)(\mathrm{CO})_{3} \mathrm{Cl}\right]$. The high activity of $\left[\operatorname{Re}\left({ }^{t} \mathrm{Bu}{ }_{2}\right.\right.$ bpy $\left.)(\mathrm{CO})_{3} \mathrm{Cl}\right]$ in dry DMF is curious since protons are necessary for catalysis by the proposed mechanisms. ${ }^{22}$ An alternative mechanism, in which $\mathrm{CO}_{2}$ serves as an oxide acceptor could be involved under anhydrous conditions. ${ }^{21,23}$ The $\left[\operatorname{Re}(4 \mathrm{DHBP})(\mathrm{CO})_{3} \mathrm{Cl}\right]$ consumed $4.1 \mathrm{C}$ in $1 \mathrm{~h}$ and produced $c a .450 \mu \mathrm{L}$ of $\mathrm{CO}$ with $95 \pm 2 \%$ Faradaic efficiency (FE). A control experiment produced ca. $6 \mu \mathrm{L}$ of CO. Adding base had little effect on catalysis. A control experiment produced $c a .6 \mu \mathrm{L}$ of $\mathrm{CO}$. Electrolysis in the presence of $5 \%$ water by volume was investigated. A control experiment 
produced $300 \mu \mathrm{L} \mathrm{CO}$ and $135 \mu \mathrm{L} \mathrm{H}$. $\left[\operatorname{Re}(4 \mathrm{DHBP})(\mathrm{CO})_{3} \mathrm{Cl}\right]$ and $\left[\mathrm{Re}\left({ }^{t} \mathrm{Bu}_{2} \mathrm{bpy}\right)(\mathrm{CO})_{3} \mathrm{Cl}\right]$ produced $\mathrm{CO}$ quantitatively with nearly identical initial rates with the latter showing slightly better stability. The mechanistic effect of water on catalysis using $\left[\mathrm{Re}(4 \mathrm{DHBP})(\mathrm{CO})_{3} \mathrm{Cl}\right]$ remains speculative. While protonation of bound $\mathrm{CO}_{2}^{-}$is possible, the acid-base properties of the ligand cannot be ignored. Since electrochemical reduction generates the ligand-deprotonated species, re-protonation by water could favor reduction of the Re instead of reductive deprotonation.

Table 3. Summary of bulk electrolysis experiments with an applied potential of $-2 \mathrm{~V} .^{a}$

\begin{tabular}{cccc}
\hline Compound & Condition & $q / \mathrm{C}$ & $\begin{array}{c}\text { Faradaic Efficiency } \\
/ \%\end{array}$ \\
\hline$\left.\left[\mathrm{Re}^{t} \mathrm{Bu}_{2} \mathrm{bpy}\right)(\mathrm{CO})_{3} \mathrm{Cl}\right]$ & dry DMF & 16.2 & quantitative \\
& $5 \% \mathrm{H}_{2} \mathrm{O} / \mathrm{DMF}$ & 20.1 & quantitative \\
{$\left[\operatorname{Re}(4 \mathrm{DHBP})(\mathrm{CO})_{3} \mathrm{Cl}\right]$} & dry DMF & 4.1 & $95 \pm 2$ \\
& $\begin{array}{c}5 \% \mathrm{H}_{2} \mathrm{O} / \mathrm{DMF} \\
\text { dry DMF }+ \\
\text { base }\end{array}$ & 15.5 & $110 \pm 9^{b}$ \\
& 4.1 & 86 \\
\hline
\end{tabular}

${ }^{a}$ Solutions were electrolyzed for $1 \mathrm{~h}$. All experiments were vigorously stirred. ${ }^{b}$ about $15 \%$ of the $\mathrm{CO}$ is produced by direct reduction at the electrode.

In dry $\mathrm{DMF},\left[\mathrm{Re}(6 \mathrm{DHBP})(\mathrm{CO})_{3} \mathrm{Cl}\right]$ consumed a comparable charge to $\left[\operatorname{Re}(4 \mathrm{DHBP})(\mathrm{CO})_{3} \mathrm{Cl}\right]$; however, only $19 \mu \mathrm{L}$ of $\mathrm{CO}$ was produced. Because of the low catalytic current for $\mathrm{CO}_{2}$ reduction by $\left[\mathrm{Re}(6 \mathrm{DHBP})(\mathrm{CO})_{3} \mathrm{Cl}\right]$ the $\mathrm{FE}$ is estimated as $6 \%$. No formate was detected by ion chromatography. In DMF / 5\% water, the $\left[\mathrm{Re}(6 \mathrm{DHBP})(\mathrm{CO})_{3} \mathrm{Cl}\right]$ catalyst performed poorly, producing barely any gaseous product over the control experiment although at least $5 \mathrm{C}$ of charge were consumed in addition to the $2 \mathrm{e}^{-}$ needed to reduce the catalyst. The product conversion was improved to $70 \% \mathrm{FE}$ at $-1.7 \mathrm{~V}(304 \mu \mathrm{L}$ compared to $8 \mu \mathrm{L}$ in a control experiment), but the turnover number was still $<1$. The absence of catalysis supports the $\left[\mathrm{CO}_{2}\right]$-independent current by $\mathrm{CV}$ while the production of $<1$ eq. $\mathrm{CO}$ suggests slow product release and decomposition of intermediates at highly negative potentials. While our original hypotheses stated that the local proton source might facilitate protonation of a $\mathrm{CO}_{2}^{-}$ligand or accelerate catalysis through secondary coordination sphere interactions, ligand based reactivity can also impede catalysis. This was discussed by Tanaka and co-workers for cis and trans isomers of $[\mathrm{Ru}(\mathrm{tpy})(\mathrm{bpyO})(\mathrm{CO})]^{+}$(tpy $=2,2^{\prime}: 6^{\prime}, 2^{\prime \prime}$-terpyridine, bpyO $=2,2^{\prime}$-bipyridin-6-onato) in which reduction of the trans isomer triggered $\mathrm{CO}$ release while the reduced cis isomer underwent attack of the pyridinato oxygen on the CO ligand. ${ }^{25}$

\section{CONCLUSIONS}

Two $f a c$ - $\left[\operatorname{Re}(\alpha\right.$-diimine $\left.)(\mathrm{CO})_{3} \mathrm{Cl}\right]$ complexes have been designed with proton responsive ligands, $4 \mathrm{DHBP}$ or $6 \mathrm{DHBP}$, to pursue the hypotheses that electron donating 4,4'-OH groups would generate a strongly nucleophilic " $\operatorname{Re}(-1)$ " center and 6,6 '$\mathrm{OH}$ groups could further facilitate catalysis by providing a proximal proton source or lowering transition state energies of rate-determining steps. We have discovered atypical properties for these complexes including stepwise electrochemical reductive electrochemical cleavage of the $\mathrm{OH}$ bond yielding the equivalent chemically deprotonated species. A mechanism for this net loss of two $\mathrm{H}$ atoms is proposed in which bipyridine doubly-reduced anions are protonated and de-aromatized. Net loss of $\mathrm{H}_{2}$ and two $\mathrm{H}^{+}$yields the deprotonated products.
While the chemical steps associated with the first two reductions occur on the ligand, the $\left[\operatorname{Re}(4 \mathrm{DHBP})(\mathrm{CO})_{3} \mathrm{Cl}\right]$ is still a competent electrocatalysts for reduction of $\mathrm{CO}_{2}$ to $\mathrm{CO}$ indicating the binding of $\mathrm{CO}_{2}$ to $\left[\operatorname{Re}\left(4 \mathrm{DHBP}-2 \mathrm{H}^{+}\right)(\mathrm{CO})_{3}\right]^{-}(\mathrm{Re}(\mathrm{I})$ formal oxidation state) followed by an electron transfer step or reduction of this species $\left(\operatorname{Re}(0)\right.$ formal oxidation state) with subsequent $\mathrm{CO}_{2}$ binding and catalysis. Experimentally, these two pathways could not be distinguished. The $\left[\operatorname{Re}(6 \mathrm{DHBP})(\mathrm{CO})_{3} \mathrm{Cl}\right]$ is not an electrocatalysts despite homologous properties to $\left[\operatorname{Re}(6 \mathrm{DHBP})(\mathrm{CO})_{3} \mathrm{Cl}\right]$ and the observation of enhanced current under $\mathrm{CO}_{2}$ by $\mathrm{CV}$. Approximately one turnover of $\mathrm{CO}$ could be obtained under optimized conditions in preparatory scale experiments suggesting the intermediate formed after $\mathrm{CO}$ release is unstable.

\section{AUTHOR INFORMATION}

\section{Corresponding Authors}

*Email: gmanbeck@bnl.gov, fujita@bnl.gov

\section{ACKNOWLEDGEMENTS}

We thank Drs. Lele Duan, David C. Grills, Javier J. Concepcion, and Dmitry E. Polyansky for helpful discussions. The work carried out at Brookhaven National Laboratory was supported by the U.S. Department of Energy, Office of Science, Division of Chemical Sciences, Geosciences, \& Biosciences, Office of Basic Energy Sciences under contract DE-SC00112704. Y. H. thanks the Japan Science and Technology Agency (JST), ACT-C for financial support.

\section{SUPPORTING INFORMATION}

X-ray structures, NMR spectra, experimental and calculated IR data, electronic transitions and orbitals from TD-DFT data, experimental and simulated cyclic voltammograms, and Cartesian coordinates of calculated structures. This material is available free of charge via the Internet at http:// pubs.acs.org.

\section{REFERENCES}

(1) Sakakura, T.; Choi, J. C.; Yasuda, H. Transformation of Carbon Dioxide. Chem. Rev. 2007, 107, 2365-2387.

(2) Rakowski, D. M.; Dubois, D. L. Development of Molecular Electrocatalysts for $\mathrm{CO}_{2}$ Reduction and $\mathrm{H}_{2}$ Production/Oxidation. Acc. Chem. Rev. 2009, 42, 1974-1982.

(3) Doherty, M. D.; Grills, D. C.; Muckerman, J. T.; Polyansky, D. E.; Fujita, E. Toward More Efficient Photochemical $\mathrm{CO}_{2}$ Reduction: Use of $\mathrm{scCO}_{2}$ or Photogenerated Hydrides. Coord. Chem. Rev. 2010, 254, 2472-2482.

(4) Windle, C. D.; Perutz, R. N. Advances in Molecular Photocatalytic and Electrocatalytic $\mathrm{CO}_{2}$ Reduction. Coord. Chem. Rev. 2012, 256, 2562-2570.

(5) Appel, A. et al. Frontiers, Opportunities, and Challenges in Biochemical and Chemical Catalysis of $\mathrm{CO}_{2}$ Fixation. Chem. Rev. 2013, 113, 6621-6658.

(6) Qiao, J. L.; Liu, Y. Y.; Hong, F.; Zhang, J. J. A Review of Catalysts for the Electroreduction of Carbon Dioxide to Produce Low-Carbon Fuels. Chem. Soc. Rev. 2014, 43, 631-675.

(7) Sullivan, B. P.; Bolinger, C. M.; Conrad, D.; Vining, W. J.; Meyer, T. J. One-Electron and 2-Electron Pathways in the Electrocatalytic Reduction of $\mathrm{CO}_{2}$ by a $f a c-\operatorname{Re}\left(2,2^{\prime}-\right.$ bipydidine $(\mathrm{CO})_{3} \mathrm{Cl}$ J. Chem. Soc., Chem. Commun. 1985, 1414-1415.

(8) Hawecker, J.; Lehn, J. M.; Ziessel, R. Photochemical and Electrochemical Reduction of Carbon Dioxide to Carbon Monoxide Mediated by (2,2'bipyridine)tricharbonylchlororhenium(I) and Related Complexes as Homogeneous Catalysts. Helv. Chim. Acta 1986, 69, 1990-2012. 
(9) Christensen, P.; Hamnett, A.; Muir, A. V. G.; Timney, J. A. An in-situ Infrared Study of $\mathrm{CO}_{2}$ Reduction Catalyzed by Rhenium Tricarbonyl Bipyridyl Derivatives. J. Chem. Soc., Dalton Trans. 1992, 1455-1463.

(10) Johnson, F. P. A.; George, M. W.; Hartl, F.; Turner, J. J. Electrocatalytic Reduction of $\mathrm{CO}_{2}$ Using the Complexes $\operatorname{Re}($ bpy $)(\mathrm{CO})_{3} \mathrm{~L}(\mathrm{n})\left(\mathrm{n}=+1, \mathrm{~L}=\mathrm{P}(\mathrm{OEt})_{3}, \mathrm{CH}_{3} \mathrm{CN} ; \mathrm{n}=0, \mathrm{~L}=\mathrm{Cl}^{-}\right.$, Otf; bpy=2,2'-bipyridine; $\quad \mathrm{Otf}^{-}=\mathrm{CF}_{3} \mathrm{SO}_{3}$ ) as Catalyst Precursors: Infrared Spectroelectrochemical Investigation. Organometallics 1996, 15, 3374-3387.

(11) Hayashi, Y.; Kita, S.; Brunschwig, B. S.; Fujita, E. Involvement of a Binuclear Species with the $\mathrm{Re}-\mathrm{C}(\mathrm{O}) \mathrm{O}-\mathrm{Re}$ Moiety in $\mathrm{CO}_{2}$ Reduction Catalyzed by Tricarbonyl Rhenium(I) Complexes with Diimine Ligands: Strikingly Slow Formation of the $\mathrm{Re}-\mathrm{Re}$ and $\mathrm{Re}-\mathrm{C}(\mathrm{O}) \mathrm{O}-\mathrm{Re}$ Species from $\mathrm{Re}(\mathrm{dmb})(\mathrm{CO})_{3} \mathrm{~S}$ ( $\mathrm{dmb}=4,4$ '-dimethyl-2,2'-bipyridine, $\mathrm{S}=$ solvent). J. Am. Chem. Soc. 2003, 125, 11976-11987.

(12) Kurz, P.; Probst, B.; Spingler, B.; Alberto, R. Ligand Variations in $\operatorname{ReX}($ diimine $)(\mathrm{CO})_{3}$ Complexes: Effects on Photocatalytic $\mathrm{CO}_{2}$ Reduction. Eur. J. Inorg. Chem. 2006, 2966-2974.

(13) Takeda, H.; Ishitani, O. Development of Efficient Photocatalytic Systems for $\mathrm{CO}_{2}$ Reduction Using Mononuclear and Multinuclear Metal Complexes Based on Mechanistic Studies. Coord. Chem. Rev. 2010, 254, 346-354.

(14) Schneider, J.; Vuong, K. Q.; Calladine, J. A.; Sun, X. Z.; Whitwood, A. C.; George, M. W.; Perutz, R. N. Photochemistry and Photophysics of a Pd(II) Metalloporphyrin: Re(I) Tricarbonyl Bipyridine Molecular Dyad and its Activity Toward the Photoreduction of $\mathrm{CO}_{2}$ to $\mathrm{CO}$. Inorg. Chem. 2011, 50, $11877-11889$.

(15) Bruckmeier, C.; Lehenmeier, M. W.; Reithmeier, R.; Rieger, B.; Herranz, J.; Kavakli, C. Binuclear Rhenium(I) Complexes for the Photocatalytic Reduction of $\mathrm{CO}_{2}$. Dalton Trans. 2012, 41, 5026-5037.

(16) Andrade, G. A.; Pistner, A. J.; Yap, G. P. A.; Lutterman, D. A.; Rosenthal, J. Photocatalytic Conversion of $\mathrm{CO}_{2}$ to $\mathrm{CO}$ Using Rhenium Bipyridine Platforms Containing Ancillary Phenyl or BODIPY Moieties. ACS Catal. 2013, 3, 1685-1692.

(17) Portenkirchner, E.; Gasiorowski, J.; Oppelt, K.; Schlager, S.; Schwarzinger, C.; Neugebauer, H.; Knoer, G.; Sariciftci, N. S. Electrocatalytic Reduction of Carbon Dioxide to Carbon Monoxide by a Polymerized Film of an Alkynyl-Substituted Rhenium(I) Complex. Chemcatchem 2013, 5, 1790-1796.

(18) Grills, D. C.; Matsubara, Y.; Kuwahara, Y.; Golisz, S. R.; Kurtz, D. A.; Mello, B. A. Electrocatalytic $\mathrm{CO}_{2}$ Reduction with a Homogeneous Catalyst in Ionic Liquid: High Catalytic Activity at Low Overpotential. J. Phys. Chem. Lett. 2014, 5, 2033-2038.

(19) Teesdale, J. J.; Pistner, A. J.; Yap, G. P. A.; Ma, Y. Z.; Lutterman, D. A.; Rosenthal, J. Reduction of $\mathrm{CO}_{2}$ Using a Rhenium Bipyridine Complex Containing Ancillary BODIPY Moieties. Catal. Today 2014, 225, 149-157.

(20) Fujita, E.; Muckerman, J. T. Why is Re-Re Bond Formation/Cleavage in $\left[\operatorname{Re}(b p y)(C O)_{3}\right]_{2}$ Different from that in $\left[\operatorname{Re}(\mathrm{CO})_{5}\right]_{2}$ ? Experimental and Theoretical Studies on the Dimers and Fragments. Inorg. Chem. 2004, 43, 7636-7647.

(21) Agarwal, J.; Fujita, E.; Schaefer, H. F., III; Muckerman, J. T. Mechanisms for $\mathrm{CO}$ Production from $\mathrm{CO}_{2}$ Using Reduced Rhenium Tricarbonyl Catalysts. J. Am. Chem. Soc. 2012, 134, 5180-5186.

(22) Keith, J. A.; Grice, K. A.; Kubiak, C. P.; Carter, E. A. Elucidation of the Selectivity of Proton-Dependent Electrocatalytic $\mathrm{CO}_{2}$ Reduction by $f a c-R e(b p y)(\mathrm{CO})_{3} \mathrm{Cl}$. J. Am. Chem. Soc. 2013, 135, 15823-15829.
(23) Agarwal, J.; Sanders, B. C.; Fujita, E.; Schaefer, H. F., III; Harrop, T. C.; Muckerman, J. T. Exploring the Intermediates of Photochemical $\mathrm{CO}_{2}$ Reduction: Reaction of $\operatorname{Re}(\mathrm{dmb})(\mathrm{CO})_{3}$ $\mathrm{COOH}$ with $\mathrm{CO}_{2}$. Chem. Commun. 2012, 48, 6797-6799.

(24) Himeda, Y.; Onozawa-Komatsuzaki, N.; Sugihara, H.; Kasuga, K. Recyclable Catalyst for Conversion of Carbon Dioxide into Formate Attributable to an Oxyanion on the Catalyst Ligand. J. Am. Chem. Soc. 2005, 127, 13118-13119.

(25) Tomon, T.; Koizumi, T.; Tanaka, K. Stabilization and Destabilization of the Ru-CO Bond During the 2,2'-bipyridin-6onato (bpyO)-Localized Redox Reaction of $\mathrm{Ru}$ (terpy)(bpyO)(CO)(PF 6$)$. Eur. J. Inorg. Chem. 2005, 285-293. (26) Hull, J. F.; Himeda, Y.; Wang, W. H.; Hashiguchi, B.; Periana, R.; Szalda, D. J.; Muckerman, J. T.; Fujita, E. Reversible Hydrogen Storage Using $\mathrm{CO}_{2}$ and a Proton-Switchable Iridium Catalyst in Aqueous Media Under Mild Temperatures and Pressures. Nat. Chem. 2012, 4, 383-388.

(27) Wang, W. H.; Hull, J. F.; Muckerman, J. T.; Fujita, E.; Himeda, Y. Second-Coordination-Sphere and Electronic Effects Enhance Iridium(III)-Catalyzed Homogeneous Hydrogenation of Carbon Dioxide in Water Near Ambient Temperature and Pressure. Energy Environ. Sci. 2012, 5, 7923-7926.

(28) Badiei, Y. M.; Wang, W. H.; Hull, J. F.; Szalda, D. J.; Muckerman, J. T.; Himeda, Y.; Fujita, E. Cp*Co(III) Catalysts with Proton-Responsive Ligands for Carbon Dioxide Hydrogenation in Aqueous Media. Inorg. Chem. 2013, 52, 12576-12586.

(29) Wang, W. H.; Muckerman, J. T.; Fujita, E.; Himeda, Y. Hydroxy-Substituted Pyridine-like N-Heterocycles: Versatile Ligands in Organometallic Catalysis. New J. Chem. 2013, 37, 1860-1866.

(30) Wang, W. H.; Muckerman, J. T.; Fujita, E.; Himeda, Y. Mechanistic Insight through Factors Controlling Effective Hydrogenation of $\mathrm{CO}_{2}$ Catalyzed by Bioinspired ProtonResponsive Iridium(III) Complexes. ACS Catal. 2013, 3, 856-860. (31) Smieja, J. M.; Kubiak, C. P. Re(bipy-tBu)(CO) $)_{3} \mathrm{Cl}$-improved Catalytic Activity for Reduction of Carbon Dioxide: IRSpectroelectrochemical and Mechanistic Studies. Inorg. Chem. 2010, 49, 9283-9289.

(32) Costentin, C.; Drouet, S.; Robert, M.; Saveant, J.-M. A Local Proton Source Enhances $\mathrm{CO}_{2}$ Electroreduction to $\mathrm{CO}$ by a Molecular Fe Catalyst. Science 2012, 338, 90-94.

(33) Hong, Y. R.; Gorman, C. B. Synthetic Approaches to an Isostructural Series of Redox-Active, Metal Tris(bipyridine) Core Dendrimers. J. Org. Chem. 2003, 68, 9019-9025.

(34) DigiSim is a registered trademark of Bioanalytical Systems, Inc

(35) Parsons, S.; Winpenny, R. E. P. Structural Chemistry of Pyridonate Complexes of Late 3d-Metals. Acc. Chem. Rev. 1997, 30, 89-95.

(36) Lynch, B. M.; Macdonal.Bc; Webb, J. G. K. NMR Spectra of Aromatic Amines and Amides I. Correlations of Amino Proton Shifts with Hammett Substituent Constants and with Huckel Electron Densities. Tetrahedron 1968, 24, 3595-3605.

(37) Giordano, P. J.; Wrighton, M. S. Nature of the Lowest Excited-state in fac-Tricarbonylhalobis(4phenylpyridine)rhenium(I) and fac-Tricarbonylhalobis(4,4'Bipyridine)rhenium(I) - Emissive Organometallic Complexes in Fluid Solution. J. Am. Chem. Soc. 1979, 101, 2888-2897.

(38) Worl, L. A.; Duesing, R.; Chen, P. Y.; Dellaciana, L.; Meyer, T. J. Photophysical Properties of Polypyridyl CarbonylComplexes of Rhenium(I). J. Chem. Soc., Dalton Trans. 1991, 849-858.

(39) Conifer, C. M.; Taylor, R. A.; Law, D. J.; Sunley, G. J.; White, A. J. P.; Britovsek, G. J. P. First Metal Complexes of 6,6'- 
dihydroxy-2,2'-bipyridine: from Molecular Wires to Applications in Carbonylation Catalysis. Dalton Trans. 2011, 40, 1031-1033.

(40) Giordano, P. J.; Bock, C. R.; Wrighton, M. S. Excited-State Proton-Transfer of Ruthenium(II) Complexes of 4,7-dihydroxy1,10-phenanthroline - Increased Acidity in Excited State. J. Am. Chem. Soc. 1978, 100, 6960-6965.

(41) Himeda, Y.; Onozawa-Komatsuzaki, N.; Sugihara, H.; Kasuga, K. Highly Efficient Conversion of Carbon Dioxide Catalyzed by Half-Sandwich Complexes with Pyridinol Ligand: The Electronic Effect of Oxyanion. J. Photochem. Photobiol. A 2006, 182, 306-309.

(42) DePasquale, J.; Nieto, I.; Reuther, L. E.; Herbst-Gervasoni, C. J.; Paul, J. J.; Mochalin, V.; Zeller, M.; Thomas, C. M.; Addison, A. W.; Papish, E. T. Iridium Dihydroxybipyridine Complexes Show That Ligand Deprotonation Dramatically Speeds Rates of Catalytic Water Oxidation. Inorg. Chem. 2013, $52,9175-9183$.

(43) Hufziger, K. T.; Thowfeik, F. S.; Charboneau, D. J.; Nieto, I.; Dougherty, W. G.; Kassel, W. S.; Dudley, T. J.; Merino, E. J.; Papish, E. T.; Paul, J. J. Ruthenium Dihydroxybipyridine Complexes are Tumor Activated Prodrugs due to low $\mathrm{pH}$ and Blue Light Induced Ligand Release. J. Inorg. Biochem. 2014, 130, 103-111.

(44) Zeng, Q.; Messaoudani, M.; Vlcek, A., Jr.; Hartl, F. Electrochemical Reductive Deprotonation of an Imidazole Ligand in a Bipyridine Tricarbonyl Rhenium(I) Complex. Eur. J. Inorg. Chem. 2012, 471-474.

(45) Paolucci, F.; Marcaccio, M.; Paradisi, C.; Roffia, S.; Bignozzi, C. A.; Amatore, C. Dynamics of the Electrochemical Behavior of Diimine Tricarbonyl Rhenium(I) Complexes in Strictly Aprotic Media. J. Phys. Chem. B 1998, 102, 4759-4769.

(46) Bard, A. J.; Faulkner, L. R. Electrochemical Methods: Fundmentals and Applications; 2nd ed.; John Wiley and Sons: New York, 2001.

(47) Costentin, C.; Drouet, S.; Robert, M.; Saveant, J.-M. Turnover Numbers, Turnover Frequencies, and Overpotential in Molecular Catalysis of Electrochemical Reactions. Cyclic
Voltammetry and Preparative-Scale Electrolysis. J. Am. Chem. Soc. 2012, 134, 11235-11242.

(48) Stor, G. J.; Hartl, F.; Vanoutersterp, J. W. M.; Stufkens, D. J. Spectroelectrochemical (IR, UV-VIS) Determination of the Reduction Pathways for a Series of $\operatorname{Re}(\mathrm{CO})_{3}$ (alpha-diimine $) \mathrm{L}^{10 /+}$ $\left(\mathrm{L}^{\prime}=\right.$ halide, $\mathrm{OTF}^{(-)}$, THF, $\left.\mathrm{MeCN}, \mathrm{n}-\mathrm{PrCN}, \mathrm{PPh}_{3}, \mathrm{P}(\mathrm{OMe})_{3}\right)$ Complexes. Organometallics 1995, 14, 1115-1131.

(49) Wong, K. Y.; Chung, W. H.; Lau, C. P. The Effect of Weak Bronsted Acids on the Electrocatalytic Reduction of Carbon Dioxide by a Rhenium Tricarbonyl Bipyridyl Complex $J$. Electroanal. Chem. 2001, 512, 128-128.

(50) Smieja, J. M.; Benson, E. E.; Kumar, B.; Grice, K. A.; Seu, C. S.; Miller, A. J. M.; Mayer, J. M.; Kubiak, C. P. Kinetic and Structural Studies, Origins of Selectivity, and Interfacial Charge Transfer in the Artificial Photosynthesis of CO. Proc. Natl. Acad. Sci. U.S.A. 2012, 109, 15646-15650.

(51) Morimoto, T.; Nakajima, T.; Sawa, S.; Nakanishi, R.; Imori, D.; Ishitani, $\mathrm{O} . \mathrm{CO}_{2}$ Capture by a Rhenium(I) Complex with the Aid of Triethanolamine. J. Am. Chem. Soc. 2013, 135, $16825-16828$

(52) Nagaoka, T.; Nishii, N.; Fujii, K.; Ogura, K. Mechanisms of Reductive Addition of $\mathrm{CO}_{2}$ to Quinones in Acetonitrile. $J$. Electroanal. Chem. 1992, 322, 383-389.

(53) Scovazzo, P.; Poshusta, J.; DuBois, D.; Koval, C.; Noble, R. Electrochemical Separation and Concentration of $<1 \%$ Carbon Dioxide from Nitrogen. J. Electrochem. Soc. 2003, 150, D91-D98.

(54) Apaydin, D. H.; Glowacki, E. D.; Portenkirchner, E.; Sariciftci, N. S. Direct Electrochemical Capture and Release of Carbon Dioxide Using an Industrial Organic Pigment: Quinacridone. Angew. Chem. Int. Ed. 2014, 53, 6819-6822.

(55) Nicholson, R. S.; Shain, I. Theory of Staionary Electrode Polarography - Single Scan Cyclic Methods Applied to Reversible, Irreversible, and Kinetic Systems. Anal. Chem. 1964, $36,706-723$. 
TOC Figure

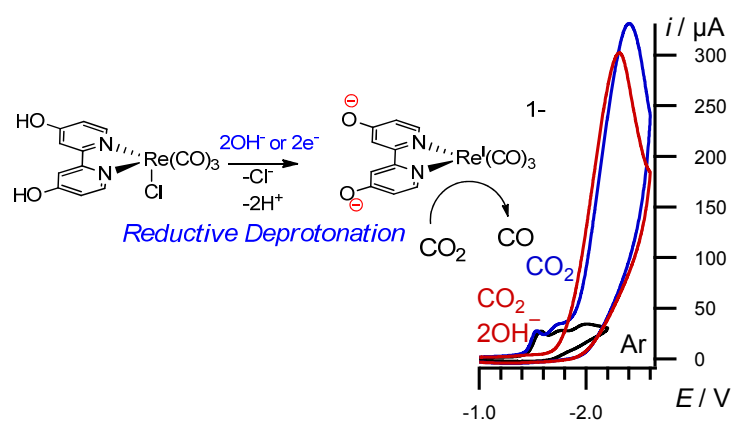




\section{Push or Pull? Proton Responsive Ligand Effects in Rhenium Tricarbonyl $\mathrm{CO}_{2}$ Reduction Catalysts}

Gerald F. Manbeck, ${ }^{, \dagger}$ James T. Muckerman, ${ }^{\dagger}$ David J. Szalda, ${ }^{\dagger, \ddagger}$ Yuichiro Himeda, ${ }^{\S}$ and Etsuko Fujita* ${ }^{\dagger}$

${ }^{\dagger}$ Department of Chemistry, Brookhaven National Laboratory, Upton, NY 11973, United States

‡ Department of Natural Science, Baruch College, CUNY, New York, New York 10o1o, United States

${ }^{\S}$ National Institute of Advanced Industrial Science and Technology, Tsukuba Central 5-2, 1-1-1 Higashi, Tsukuba, Ibaraki, 305-8565, Japan, and Japan Science and Technology Agency, ACT-C, 4-1-8, Honcho,

Kawaguchi, Saitama, 332-0012, Japan

*corresponding authors: Email: gmanbeck@bnl.gov, fujita@bnl.gov

\section{Supporting Information}




\section{Contents:}

\begin{tabular}{|c|c|c|}
\hline & Experimental Details & S3 \\
\hline Figure S1 & ORTEP drawing of $\left[\mathrm{Re}(4 \mathrm{DHBP})(\mathrm{CO})_{3} \mathrm{Cl}\right] \cdot 2 \mathrm{DMSO}$. & S4 \\
\hline Table S1 & $\begin{array}{l}\text { Crystallographic collection and refinement data for } \\
{\left[\operatorname{Re}(4 \mathrm{DHBP})(\mathrm{CO})_{3} \mathrm{Cl}\right] \cdot 2 \mathrm{DMSO} \text {. }}\end{array}$ & S4 \\
\hline Tables S2-4 & Tables of bond lengths and angles. & S5 \\
\hline Figure S2 & $\begin{array}{l}{ }^{1} \mathrm{H} \text { NMR spectra of }\left[\mathrm{Re}(4 \mathrm{DHBP})(\mathrm{CO})_{3} \mathrm{Cl}\right] \text { and }\left[\mathrm{Re}(6 \mathrm{DHBP})(\mathrm{CO})_{3} \mathrm{Cl}\right] \text {, species } \\
\text { obtained by chemical deprotonation, and species obtained by reductive } \\
\text { electrolysis. }\end{array}$ & S6 \\
\hline Table S5 & $\begin{array}{l}\text { Calculated lowest energy optical transitions for }\left[\operatorname{Re}(6 \mathrm{DHBP})(\mathrm{CO})_{3} \mathrm{Cl}\right] \text { and } \\
{\left[\mathrm{Re}(4 \mathrm{DHBP})(\mathrm{CO})_{3} \mathrm{Cl}\right] \text { in water. }}\end{array}$ & S7 \\
\hline Figure S3 & $\begin{array}{l}\text { Frontier molecular orbitals of }\left[\mathrm{Re}(6 \mathrm{DHBP})(\mathrm{CO})_{3} \mathrm{Cl}\right] \text { and } \\
{\left[\operatorname{Re}(4 \mathrm{DHBP})(\mathrm{CO})_{3} \mathrm{Cl}\right] .}\end{array}$ & S7 \\
\hline Figure S4 & $\begin{array}{l}\text { Spectrophotometric } \mathrm{pH} \text { titration of }\left[\mathrm{Re}(4 \mathrm{DHBP})(\mathrm{CO})_{3} \mathrm{Cl}\right] \text { and } \\
{\left[\mathrm{Re}(6 \mathrm{DHBP})(\mathrm{CO})_{3} \mathrm{Cl}\right] \text { in water. }}\end{array}$ & S8 \\
\hline Figure S5 & Spectrophotometric $\mathrm{pH}$ titration of $\left[\mathrm{Re}(6 \mathrm{DHBP})(\mathrm{CO})_{3} \mathrm{Cl}\right]$ in acetonitrile. & S8 \\
\hline Figure S6 & Cyclic voltammetry of $\left[\mathrm{Re}\left({ }^{t} \mathrm{Bu}_{2}\right.\right.$ bpy $\left.)(\mathrm{CO})_{3} \mathrm{Cl}\right]$ in $\mathrm{DMF}$. & S9 \\
\hline Figure S7 & Cyclic voltammetry of $\left[\mathrm{Re}(4 \mathrm{DHBP})(\mathrm{CO})_{3} \mathrm{Cl}\right]$ in DMF. & S9 \\
\hline Figure S8 & Simulated CV for the $1 \mathrm{e}^{-}$reduction of $\left[\mathrm{Re}(4 \mathrm{DHBP})(\mathrm{CO})_{3} \mathrm{Cl}\right]$ in $\mathrm{DMF}$. & S10 \\
\hline Figure S9-10 & Cyclic voltammetry of $\left[\mathrm{Re}(6 \mathrm{DHBP})(\mathrm{CO})_{3} \mathrm{Cl}\right]$ in DMF. & S10-11 \\
\hline Figure S11 & Spectroelectrochemical IR of $\left[\mathrm{Re}(6 \mathrm{DHBP})(\mathrm{CO})_{3} \mathrm{Cl}\right]$ in $\mathrm{CH}_{3} \mathrm{CN}$. & S12 \\
\hline Figure S12 & Spectroelectrochemical IR of $\left[\operatorname{Re}\left({ }^{t} \mathrm{Bu}_{2} \mathrm{bpy}\right)(\mathrm{CO})_{3} \mathrm{Cl}\right]$ in DMF. & S12 \\
\hline Figure S13 & Calculated IR data for species derived from $\left[\mathrm{Re}(4 \mathrm{DHBP})(\mathrm{CO})_{3} \mathrm{Cl}\right]$. & S13 \\
\hline Figure S14 & Calculated IR data for species derived from $\left[\mathrm{Re}(6 \mathrm{DHBP})(\mathrm{CO})_{3} \mathrm{Cl}\right]$. & S14 \\
\hline Table S6 & $\begin{array}{l}\text { Two-electron reduction free-energy pathway to doubly deprotonated species } \\
\text { of }\left[\operatorname{Re}^{\mathrm{I}}(4 \mathrm{DHBP})(\mathrm{CO})_{3}(\mathrm{DMF})\right]^{+} \text {. }\end{array}$ & S15 \\
\hline Table S7 & $\begin{array}{l}\text { One-electron reduction free-energy pathway to singly deprotonated species of } \\
{\left[\operatorname{Re}^{\mathrm{I}}(4 \mathrm{DHBP})(\mathrm{CO})_{3}(\mathrm{DMF})\right]^{+} \text {. }}\end{array}$ & S15 \\
\hline Figure S15 & $\begin{array}{l}\text { Free-energy profiles for two-electron and one-electron reduction pathways } \\
\text { from }\left[\operatorname{Re}^{\mathrm{I}}(4 \mathrm{DHBP})(\mathrm{CO})_{3}(\mathrm{DMF})\right]^{+} \text {to the doubly and singly deprotonated } \\
\text { intermediates, respectively. }\end{array}$ & S16 \\
\hline Figure S16 & $\begin{array}{l}\text { Cyclic voltammograms of chemically deprotonated }\left[\mathrm{Re}(6 \mathrm{DHBP})(\mathrm{CO})_{3} \mathrm{Cl}\right] \\
\text { under } \mathrm{Ar}, \mathrm{CO}_{2} \text {, or a } 30 \% \mathrm{CO}_{2} \text { in } \mathrm{N}_{2} \text { mixture. }\end{array}$ & S17 \\
\hline \multirow[t]{2}{*}{ Tables S8-21 } & Cartesian coordinates of calculates structures. & S17-30 \\
\hline & References & S31 \\
\hline
\end{tabular}


2.2. X-ray Crystallography. A crystal of $\left[\mathrm{Re}(4 \mathrm{DHBP})(\mathrm{CO})_{3} \mathrm{Cl}\right] \cdot 2\left(\mathrm{CH}_{3}\right)_{2} \mathrm{SO}$ was mounted on the end of a glass fiber. Data were collected with a Bruker Kappa Apex II diffractometer. Data collected at $173 \mathrm{~K}$ indicated triclinic symmetry and space group $P-1$ was used for the solution and refinement of the structure. The intensity data were corrected for absorption using the multi-scan method (SADABS). ${ }^{1,2}$ The structure was solved by Patterson heavy atom methods. ${ }^{3}$ Non-hydrogen atoms were refined with anisotropic displacement parameters except for the carbon atoms in the disordered DMSO molecule with an occupancy factor of 0.23 . Most hydrogen atoms were placed in ideal positions and refined as riding atoms with relative isotropic thermal parameters. The hydrogen atoms on O14 and O24 of the 4DHBP ligand were located on a difference Fourier map and included in fixed positions. A disordered model was used for one DMSO molecule and the occupancy factor for was refined. Crystal data and refinement parameters are provided as supplementary material.

2.3. DFT Calculations. Calculations were carried out using the B3LYP hybrid functional ${ }^{4,5,6,7}$ with the 6-31++G(d,p) 5d basis set for $\mathrm{C}, \mathrm{H}, \mathrm{N}$, and $\mathrm{O}$ atoms and CEP effective core potential with CEP-121G basis for $\mathrm{Re}^{8,9,10}$ as implemented by the Gaussian 09 suite of programs. ${ }^{11}$ The CPCM solvent model was used, ${ }^{12,13,14}$ and all geometry optimizations and vibrational frequency calculations were carried out in this model of the solvent with UAHF radii. Free energies of non-gas solutes were corrected for conversion of an ideal gas at $1 \mathrm{~atm}$ to $1 \mathrm{M}$ standard state, ${ }^{15}$ and an additional correction to adjust the standard state of DMF to a pure liquid was applied. ${ }^{16}$ Standard reduction potentials were calculated vs. NHE in DMF (4.17 V) which was obtained using the calculated absolute free energy of $\mathrm{H}_{2}$ gas, the free energy of the gasphase electron ${ }^{17}$ and the absolute free energy of the proton solvated in DMF. This last value $(-273.3$ $\mathrm{kcal} / \mathrm{mol}$ ) was determined as that which gave the correct $\mathrm{p} K_{\mathrm{a}}$ value (18.4) of phenol in DMF using calculated absolute free energies of phenol and its conjugate base in DMF solution. IR spectra were visualized using GaussSum with fwhm $=8 \mathrm{~cm}^{-1} \cdot{ }^{18} \mathrm{UV}$-vis spectra in aqueous solution were calculated using the TD-B3LYP method and the CPCM solvation model with water solvent and UAHF radii.

\subsection{Cyclic Voltammetry of $\left[\operatorname{Re}(6 \mathrm{DHBP})(\mathrm{CO})_{3} \mathrm{Cl}\right]$ under Argon.}

The reductive $\mathrm{CV}$ of $\left[\mathrm{Re}(6 \mathrm{DHBP})(\mathrm{CO})_{3} \mathrm{Cl}\right]$ (Figure $\left.\mathrm{S} 9\right)$ exhibits features similar to $\left[\operatorname{Re}(4 \mathrm{DHBP})(\mathrm{CO})_{3} \mathrm{Cl}\right]$. with irreversible reduction peaks at $E_{p}{ }^{c}=-1.53$ and $-1.75 \mathrm{~V}$ followed by a poorly resolved reduction wave which acquires a peak shape with $E_{\mathrm{p}}{ }^{\mathrm{c}}=-2.0 \mathrm{~V}$ at higher scan rates. The first reduction becomes quasi-reversible at higher scan rates and the diffusion coefficient is estimated as $8.6 \times$ $10^{-7} \mathrm{~cm}^{2} \mathrm{~s}^{-1}$. For $\left[\mathrm{Re}(6 \mathrm{DHBP})(\mathrm{CO})_{3} \mathrm{Cl}\right]$, higher scan rates were needed to observe the anodic counterpart of R1, and R3 was only present for higher scan rates indicating a faster $k_{l}$, but simulation was not performed since the absence of an isopotential point in Figure S9 shows the first reduction couple was not isolated from following electrochemical steps.

The anodic $\mathrm{CV}$ after reduction shows a small wave $\mathrm{O} 1$ at $0.76 \mathrm{~V}$ associated with re-oxidation followed by irreversible waves at 1.25 and $1.45 \mathrm{~V}$ analogous to $\mathrm{O} 3$ in $\left[\mathrm{Re}(6 \mathrm{DHBP})(\mathrm{CO})_{3} \mathrm{Cl}\right]$ (Figures $\left.\mathrm{S} 10\right)$. After electrolysis at $-1.6 \mathrm{~V}$, reductive waves are absent and new oxidations $\mathrm{O} 4(0.50 \mathrm{~V})$ and $\mathrm{O} 5(1.04 \mathrm{~V})$ appeared. Peak $\mathrm{O} 5$ is chloride oxidation while $\mathrm{O} 4$ is analogous to $\mathrm{O} 4$ in $\left[\mathrm{Re}(4 \mathrm{DHBP})(\mathrm{CO}){ }_{3} \mathrm{Cl}\right]$. The $\mathrm{CV}$ of the chemically deprotonated complex is identical to the electrochemically reduced complex. An irreversible reduction, $\mathrm{R} 3$ was observed at $-2.43 \mathrm{~V}$. 


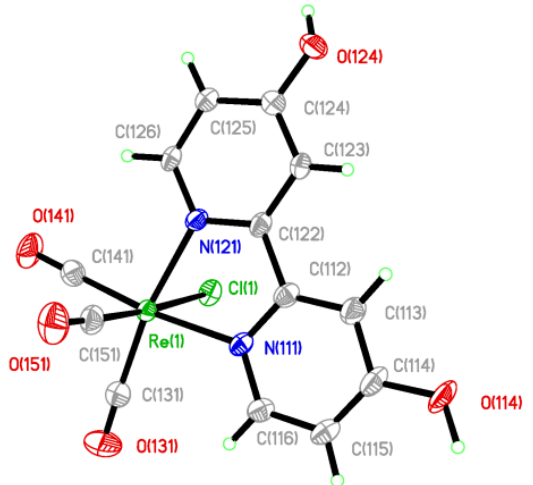

Figure S1. ORTEP drawing of $\left[\mathrm{Re}(4 \mathrm{DHBP})(\mathrm{CO})_{3} \mathrm{Cl} \cdot 2 \mathrm{DMSO}\right]$ with $50 \%$ probability ellipsoids. Two cocrystallized DMSO molecules have been omitted for clarity.

Table S1. Crystallographic collection and refinement data for $\left[\operatorname{Re}(4 \mathrm{DHBP})(\mathrm{CO})_{3} \mathrm{Cl}\right] \cdot 2 \mathrm{DMSO}$

\begin{tabular}{|c|c|}
\hline formula & $\mathrm{C}_{17} \mathrm{H}_{20} \mathrm{ClN}_{2} \mathrm{O}_{7} \mathrm{ReS}_{2}$ \\
\hline formula weight & 650.12 \\
\hline temperature & $173(2) \mathrm{K}$ \\
\hline crystal system & Triclinic \\
\hline space group & $P-1$ \\
\hline$a(\AA)$ & $6.5699(2)$ \\
\hline$b(\AA)$ & $12.6534(3)$ \\
\hline$c(\AA)$ & $14.5494(3)$ \\
\hline$\alpha(\operatorname{deg})$ & $72.7900(10)$ \\
\hline$\beta(\operatorname{deg})$ & $82.8670(10)$ \\
\hline$\gamma(\operatorname{deg})$ & $77.6420(10)$ \\
\hline$V\left(\AA^{3}\right)$ & $1126.19(5)$ \\
\hline Z & 2 \\
\hline$\mu$ & $5.739 \mathrm{~mm}^{-1}$ \\
\hline$\lambda(\AA)$ & 0.71073 \\
\hline$\rho$ calc $\left(\mathrm{g} \mathrm{cm}^{-3}\right)$ & 1.917 \\
\hline crystal size (mm) & $0.33 \times 0.03 \times 0.03$ \\
\hline$\theta$ range (deg) & 2.55 to 30.12 \\
\hline total number of reflections & 35416 \\
\hline no. independent reflections & $6581 \mathrm{R}(\mathrm{int})=0.0455$ \\
\hline no. parameters & 298 \\
\hline Final $\mathrm{R}$ indices $\mathrm{I} \geq 3 \sigma$ & $\begin{array}{l}\mathrm{R} 1=0.0304, \mathrm{wR} 2= \\
0.0540\end{array}$ \\
\hline $\mathrm{R}$ indices (all data) & $\begin{array}{l}\mathrm{R} 1=0.0430, \mathrm{wR} 2= \\
0.0568\end{array}$ \\
\hline Goodness-of-fit on F2 & 1.034 \\
\hline Absorption correction & $\begin{array}{l}\text { semi-empirical from } \\
\text { equivalents }\end{array}$ \\
\hline
\end{tabular}

$\mathrm{R} 1=\Sigma|| \mathrm{F}_{\mathrm{O}}|-| \mathrm{F}_{\mathrm{C}}|/ \Sigma| \mathrm{F}_{\mathrm{O}} \mid ; \quad \mathrm{wR} 2=\left\{\Sigma\left[\mathrm{w}\left(\left|\mathrm{F}_{\mathrm{O}}{ }^{2}\right|-\left|\mathrm{F}_{\mathrm{C}}{ }^{2}\right|\right)^{2}\right] / \Sigma\left[\mathrm{w}\left|\mathrm{F}_{\mathrm{O}}{ }^{2}\right|^{2}\right]\right\}^{1 / 2}$ 
Table S2. Comparison of bond lengths $[\AA]$ and angles $[\mathrm{deg}]$ to $\left[\mathrm{Re}(\mathrm{bpy})(\mathrm{CO})_{3} \mathrm{Cl}\right]$.

\section{$\left[\operatorname{Re}(4 \mathrm{DHBP})(\mathrm{CO})_{3} \mathrm{Cl}\right] \cdot 2 \mathrm{DMSO} \quad\left[\mathrm{Re}(\mathrm{bpy})(\mathrm{CO})_{3} \mathrm{Cl}\right]$}

\begin{tabular}{lcc}
\hline & $2.177(3)$ & \\
$\operatorname{Re}(1)-\mathrm{N}(111)$ & $2.163(3)$ & $2.176(6)$ \\
$\operatorname{Re}(1)-\mathrm{N}(211)$ & $1.916(4)$ & $2.173(6)$ \\
$\operatorname{Re}(1)-\mathrm{C}(131)$ & $1.911(4)$ & $1.919(7)$ \\
$\operatorname{Re}(1)-\mathrm{C}(141)$ & $1.906(4)$ & $1.932(7)$ \\
$\operatorname{Re}(1)-\mathrm{C}(151)$ & $2.5058(8)$ & $1.938(9)$ \\
$\operatorname{Re}(1)-\mathrm{Cl}(1)$ & $74.41(9)$ & $2.460(2)$ \\
$\mathrm{N}(121)-\operatorname{Re}(1)-\mathrm{N}(111)$ & $86.09(7)$ & $74.9(2)$ \\
$\mathrm{N}(111)-\operatorname{Re}(1)-\mathrm{Cl}(1)$ & $83.00(7)$ & $85.7(2)$ \\
$\mathrm{N}(121)-\operatorname{Re}(1)-\mathrm{Cl}(1)$ & $92.67(11)$ & $83.5(2)$ \\
$\mathrm{C}(131)-\operatorname{Re}(1)-\mathrm{Cl}(1)$ & $91.00(10)$ & $92.1(2)$ \\
$\mathrm{C}(141)-\operatorname{Re}(1)-\mathrm{Cl}(1)$ & $176.31(10)$ & $93.8(2)$ \\
$\mathrm{C}(151)-\operatorname{Re}(1)-\mathrm{Cl}(1)$ & $97.09(12)$ & $171.3(3)$ \\
$\mathrm{C}(131)-\operatorname{Re}(1)-\mathrm{N}(111)$ & $173.34(12)$ & $97.8(3)$ \\
$\mathrm{C}(141)-\operatorname{Re}(1)-\mathrm{N}(111)$ & $95.00(12)$ & $172.5(3)$ \\
$\mathrm{C}(151)-\operatorname{Re}(1)-\mathrm{N}(111)$ & $170.65(12)$ & $91.0(3)$ \\
$\mathrm{C}(131)-\operatorname{Re}(1)-\mathrm{N}(121)$ & $99.31(12)$ & $172.4(3)$ \\
$\mathrm{C}(141)-\operatorname{Re}(1)-\mathrm{N}(121)$ & $93.89(13)$ & $97.3(3)$ \\
$\mathrm{C}(151)-\operatorname{Re}(1)-\mathrm{N}(121)$ & $89.02(14)$ & $92.8(3)$ \\
$\mathrm{C}(141)-\operatorname{Re}(1)-\mathrm{C}(131)$ & $90.69(15)$ & $89.5(3)$ \\
$\mathrm{C}(151)-\operatorname{Re}(1)-\mathrm{C}(131)$ & $87.54(14)$ & $90.8(4)$ \\
$\mathrm{C}(141)-\operatorname{Re}(1)-\mathrm{C}(151)$ & & $89.4(4)$
\end{tabular}

Table S3. Hydrogen bonds details for $\left[\operatorname{Re}(4 \mathrm{DHBP})(\mathrm{CO})_{3} \mathrm{Cl}\right] \cdot 2 \mathrm{DMSO}[\AA$ and deg. $]$.

\begin{tabular}{llllll}
\hline $\mathrm{D}-\mathrm{H}$ & $\mathrm{d}(\mathrm{D}-\mathrm{H})$ & $\mathrm{d}(\mathrm{H} . \mathrm{A})$ & $<\mathrm{DHA}$ & $\mathrm{d}(\mathrm{D} \ldots \mathrm{A})$ & \multicolumn{1}{c}{$\mathrm{A}$} \\
$0114-\mathrm{H} 114$ & 0.968 & 1.509 & 156.68 & 2.429 & $021 \mathrm{~A} \_b$ \\
$0114-\mathrm{H} 114$ & 0.968 & 1.649 & 164.06 & 2.594 & $021 \_\mathrm{a}$ \\
$0114-\mathrm{H} 114$ & 0.968 & 2.618 & 159.11 & 3.540 & S21A_b \\
$0114-\mathrm{H} 114$ & 0.968 & 2.737 & 166.57 & 3.686 & S21_a \\
$0124-\mathrm{H} 124$ & 0.844 & 1.785 & 155.92 & 2.578 & $011[\mathrm{x}+1, y, z]$
\end{tabular}

Table S4. $\mathrm{Cl} \cdots \mathrm{H}$ distances in $\left[\mathrm{Re}(4 \mathrm{DHBP})(\mathrm{CO})_{3} \mathrm{Cl}\right] \cdot 2 \mathrm{DMSO}[\AA]$.

\begin{tabular}{llll}
\hline $\mathrm{Cl}(1) \cdots \mathrm{H} 125$ & 2.864 & $\mathrm{x}-1, \mathrm{y}, \mathrm{z}$ \\
$\mathrm{Cl}(1) \cdots \mathrm{H} 126$ & 2.893 & $\mathrm{x}-1, \mathrm{y}, \mathrm{z}$ \\
$\mathrm{Cl}(1) \cdots \mathrm{H} 12 \mathrm{~A}$ & 3.069 & $1-\mathrm{x}, 1-\mathrm{y}, 2-\mathrm{z}$ \\
$\mathrm{Cl}(1) \cdots \mathrm{H} 12 \mathrm{~B}$ & 2.917 & $2-\mathrm{x},-\mathrm{y}, 2-\mathrm{z}$ \\
$\mathrm{Cl}(1) \cdots \mathrm{H} 12 \mathrm{C}$ & 2.981 & & \\
$\mathrm{Cl}(1) \cdots \mathrm{H} 13 \mathrm{~A}$ & 3.209 & & \\
$\mathrm{Cl}(1) \cdots \mathrm{H} 23 \mathrm{E}$ & 2.947 & $1+x, y-1, \mathrm{z}$
\end{tabular}




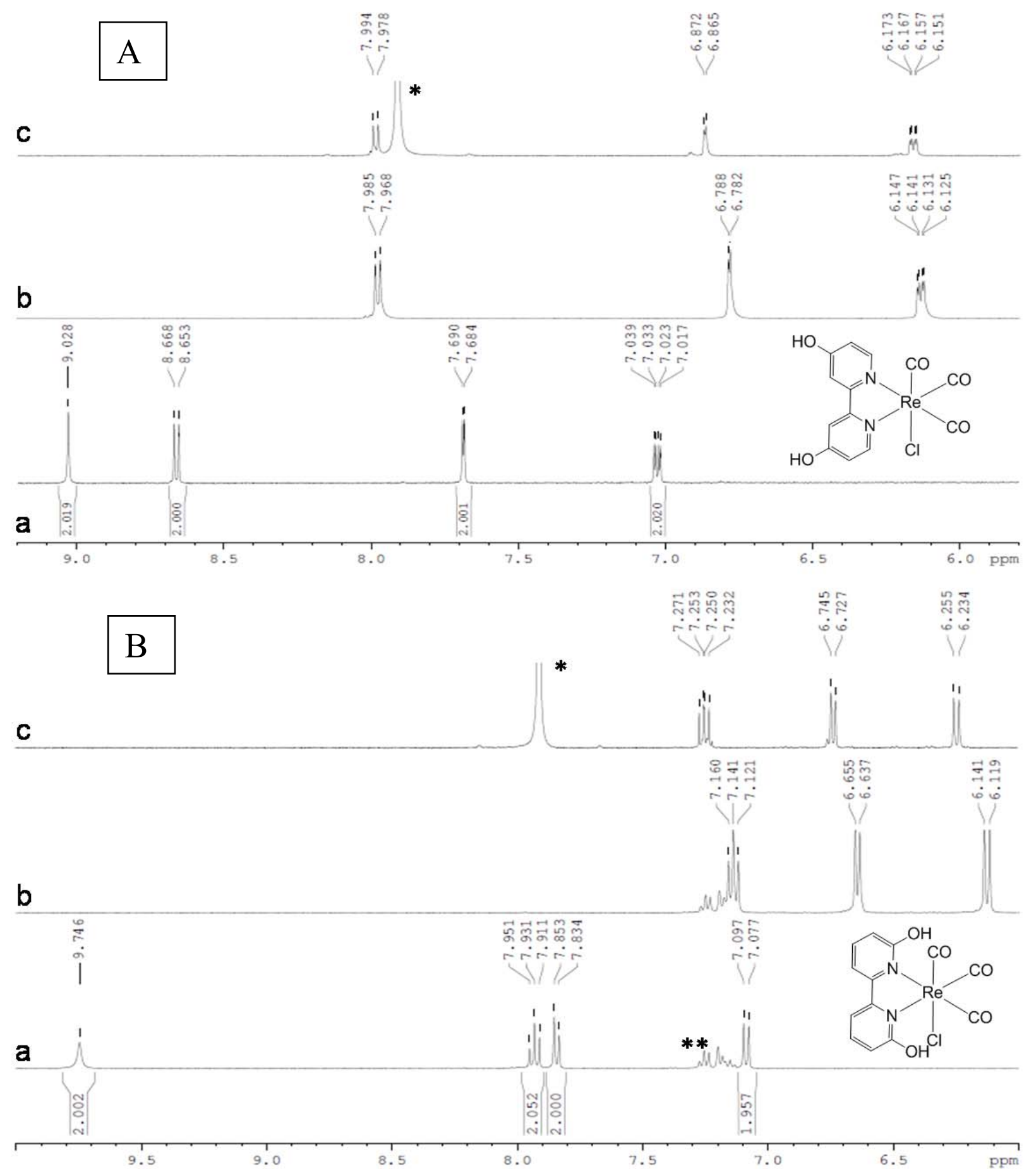

Figure S2. ${ }^{1} \mathrm{H}$ NMR spectra of isolated $(\mathrm{A})\left[\mathrm{Re}(4 \mathrm{DHBP})(\mathrm{CO})_{3} \mathrm{Cl}\right]$ and $(\mathrm{B})\left[\mathrm{Re}(6 \mathrm{DHBP})(\mathrm{CO})_{3} \mathrm{Cl}\right]$. (a): the isolated complex, (b): the in-situ chemically deprotonated complex generated by treatment of with 2 eq. $\mathrm{Bu}_{4} \mathrm{NOH}\left(1 \mathrm{M}\right.$ solution in methanol), and (c): the electrochemically reduced complex in $\mathrm{CD}_{3} \mathrm{CN}$. ${ }^{*} \mathrm{DMF}$ contamination from the Vycor-tipped glass tube separating the reference electrode from the electrolysis solution. ${ }^{* *}$ Residual toluene co-crystallized during synthesis which can be removed by dissolution in $\mathrm{CH}_{3} \mathrm{CN}$ and precipitation with ether. See experimental details in the text for sample preparation. 
Table S5. Calculated lowest energy optical transitions for $\left[\operatorname{Re}(6 \mathrm{DHBP})(\mathrm{CO})_{3} \mathrm{Cl}\right]$ and $\left[\operatorname{Re}(4 \mathrm{DHBP})(\mathrm{CO})_{3} \mathrm{Cl}\right]$ in water. Only transitions with pure orbital character are listed. Higher energy transitions include states with significant orbital mixing.

\begin{tabular}{lcccc}
\hline & Wavelength & $\begin{array}{c}\text { Oscillator } \\
\text { Strength }\end{array}$ & Orbital Character \\
\hline$\left[\operatorname{Re}(6 \mathrm{DHBP})(\mathrm{CO})_{3} \mathrm{Cl}\right]$ & 1 & 398 & 0.0014 & HOMO $\rightarrow$ LUMO (99\%) \\
& 2 & 380 & 0.074 & $\mathrm{H}-1 \rightarrow$ LUMO $(99 \%)$ \\
& 3 & 355 & 0.0003 & $\mathrm{H}-3 \rightarrow$ LUMO $(98 \%)$ \\
& 4 & 337 & 0.3709 & $\mathrm{H}-2 \rightarrow$ LUMO $(96 \%)$ \\
{$\left[\operatorname{Re}(4 \mathrm{DHBP})(\mathrm{CO})_{3} \mathrm{Cl}\right]$} & 1 & 375 & 0.0024 & HOMO $\rightarrow$ LUMO (98\%) \\
& 2 & 362 & 0.0904 & $\mathrm{H}-1 \rightarrow$ LUMO $(98 \%)$ \\
& 3 & 330 & 0.001 & $\mathrm{H}-2 \rightarrow$ LUMO $(96 \%)$ \\
\hline
\end{tabular}

\section{$\left[\mathrm{Re}(6 \mathrm{DHBP})(\mathrm{CO})_{3} \mathrm{Cl}\right]$}

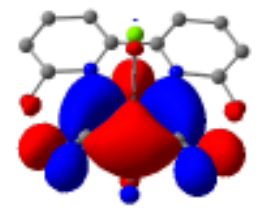

HOMO-3

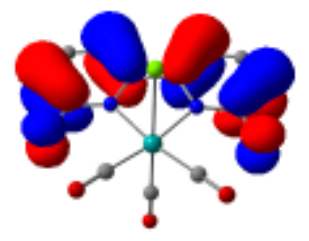

HOMO-2

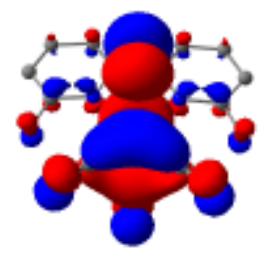

HOMO-1

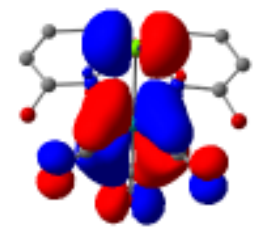

HOMO

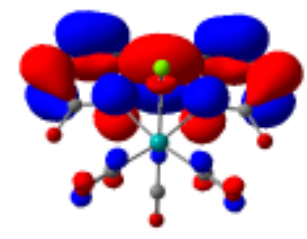

LUMO

\section{$\left[\mathrm{Re}(4 \mathrm{DHBP})(\mathrm{CO})_{3} \mathrm{Cl}\right]$}

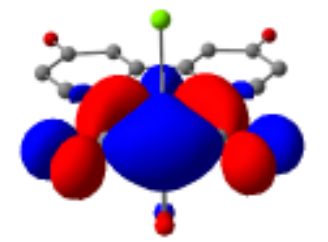

HOMO-2

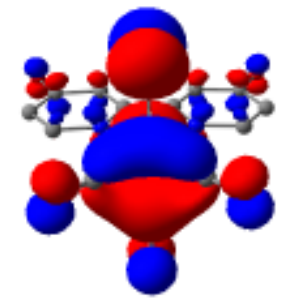

HOMO-1

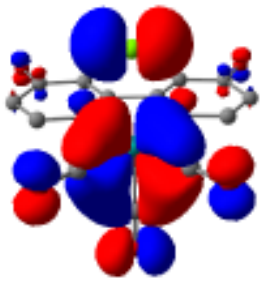

HOMO

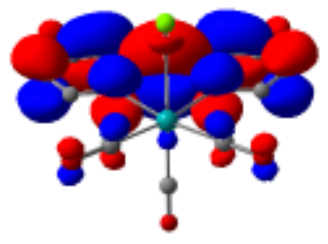

LUMO

Figure S3. Frontier molecular orbitals of $\left[\mathrm{Re}(6 \mathrm{DHBP})(\mathrm{CO})_{3} \mathrm{Cl}\right]$ and $\left[\mathrm{Re}(4 \mathrm{DHBP})(\mathrm{CO})_{3} \mathrm{Cl}\right]$ showing orbitals contributing to the lowest energy electronic transitions (Table S1). 

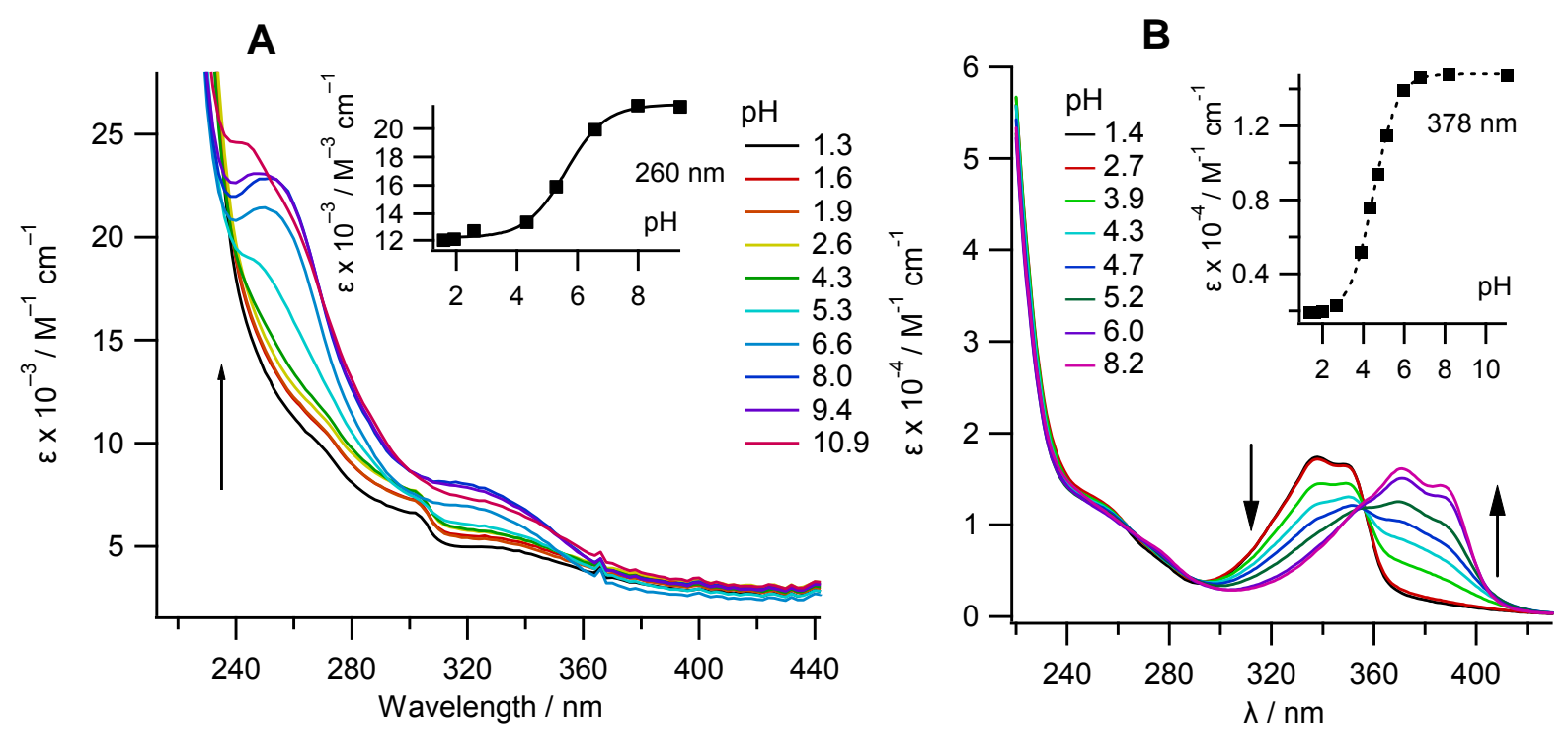

Figure S4. A: Spectrophotometric $\mathrm{pH}$ titration of $\left[\mathrm{Re}(4 \mathrm{DHBP})(\mathrm{CO}){ }_{3} \mathrm{Cl}\right]$ in Britton-Robinson buffer with $1 \% \mathrm{CH}_{3} \mathrm{CN}$ co-solvent. Inset: $\varepsilon$ as a function of $\mathrm{pH}$ and sigmoidal fits used to determine the average $\mathrm{p} K_{\mathrm{a}}$ of 5.6. B: Spectrophotometric $\mathrm{pH}$ titration of $\left[\operatorname{Re}(6 \mathrm{DHBP})(\mathrm{CO})_{3} \mathrm{Cl}\right]$ in Britton-Robinson buffer. Inset: $\varepsilon$ as a function of $\mathrm{pH}$ and sigmoidal fits used to determine the average $\mathrm{p} K_{\mathrm{a}}$ of 4.5 .

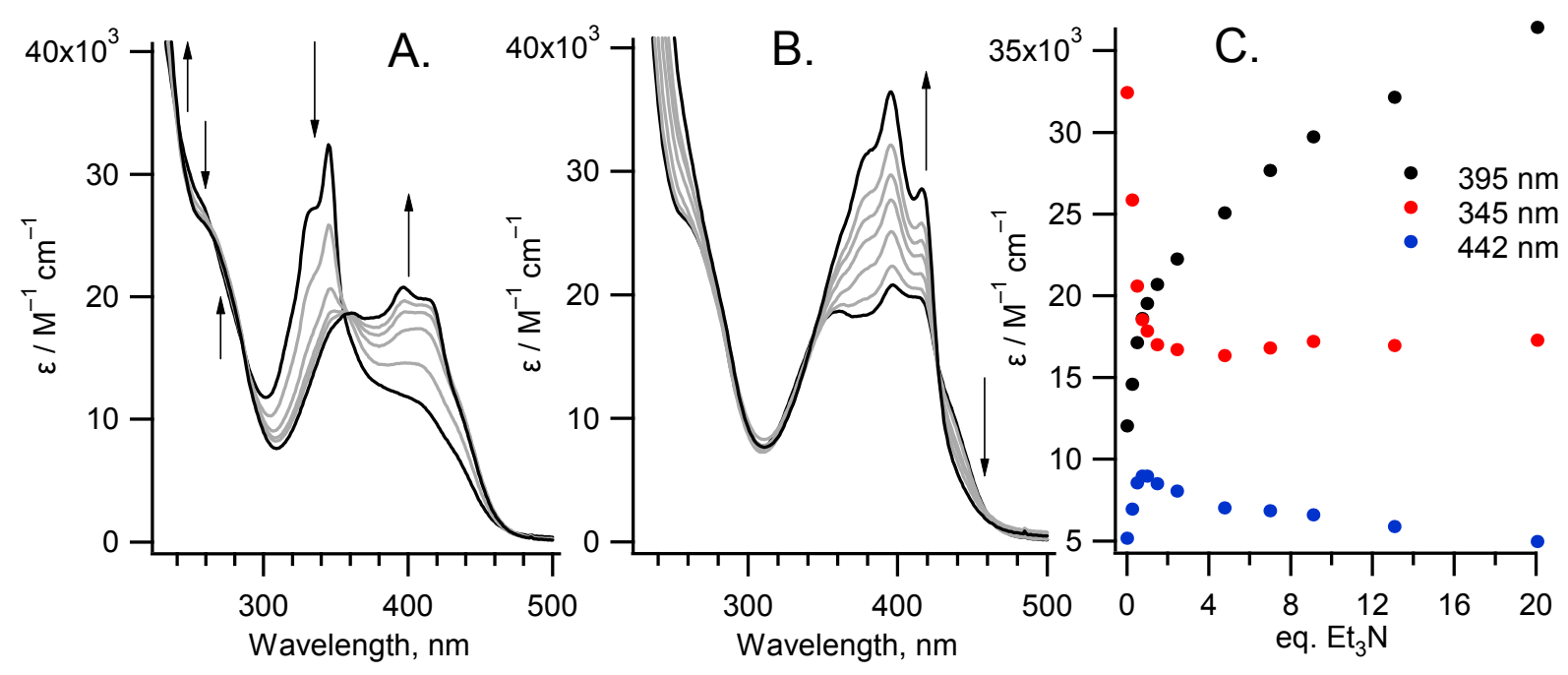

Figure S5. Spectrophotometric $\mathrm{pH}$ titration of $\left[\mathrm{Re}(6 \mathrm{DHBP})(\mathrm{CO})_{3} \mathrm{Cl}\right]$ in $\mathrm{CH}_{3} \mathrm{CN}$ using $\mathrm{Et}_{3} \mathrm{~N}$ as the base. A: $0,0.25,0.5,0.75,1.0,1.5$ eq. $\mathrm{Et}_{3} \mathrm{~N}$. B: $1.5,2.4,4.8,7.0,9.1,13,30$ eq. $\mathrm{Et}_{3} \mathrm{~N}$. C: Plots of $\varepsilon$ vs. eq. $\mathrm{Et}_{3} \mathrm{~N}$ at 395,345 , and $442 \mathrm{~nm}$. 

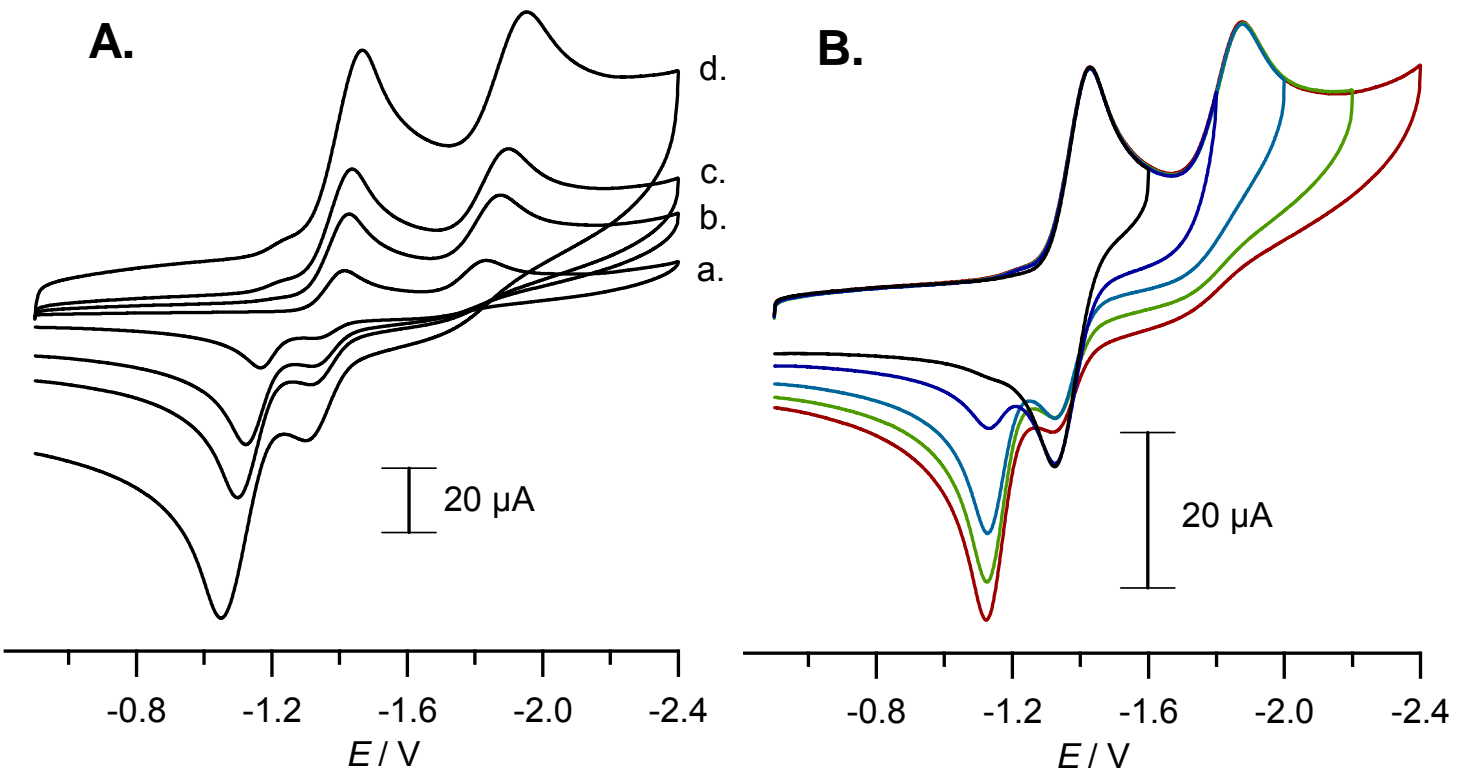

Figure S6. (A) Cyclic voltammograms showing scan rate dependence of the two-electron reduction of

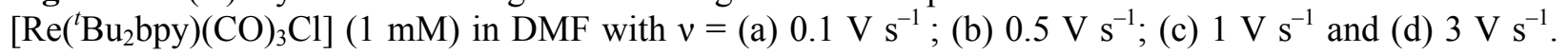
(B) Cyclic voltammograms showing the effect of cathodic switching potential on the re-oxidation processes $\left(v=0.5 \mathrm{~V} \mathrm{~s}^{-1}\right)$. The diffusion coefficient in DMF was calculated as $3.0 \times 10^{-6} \mathrm{~cm}^{2} / \mathrm{s}$ from a plot of $i_{\mathrm{p}}{ }^{\mathrm{c}} \mathrm{vs} v^{1 / 2}$. Potentials are referenced to $\mathrm{Ag} / \mathrm{AgCl}(3 \mathrm{M} \mathrm{KCl})$.

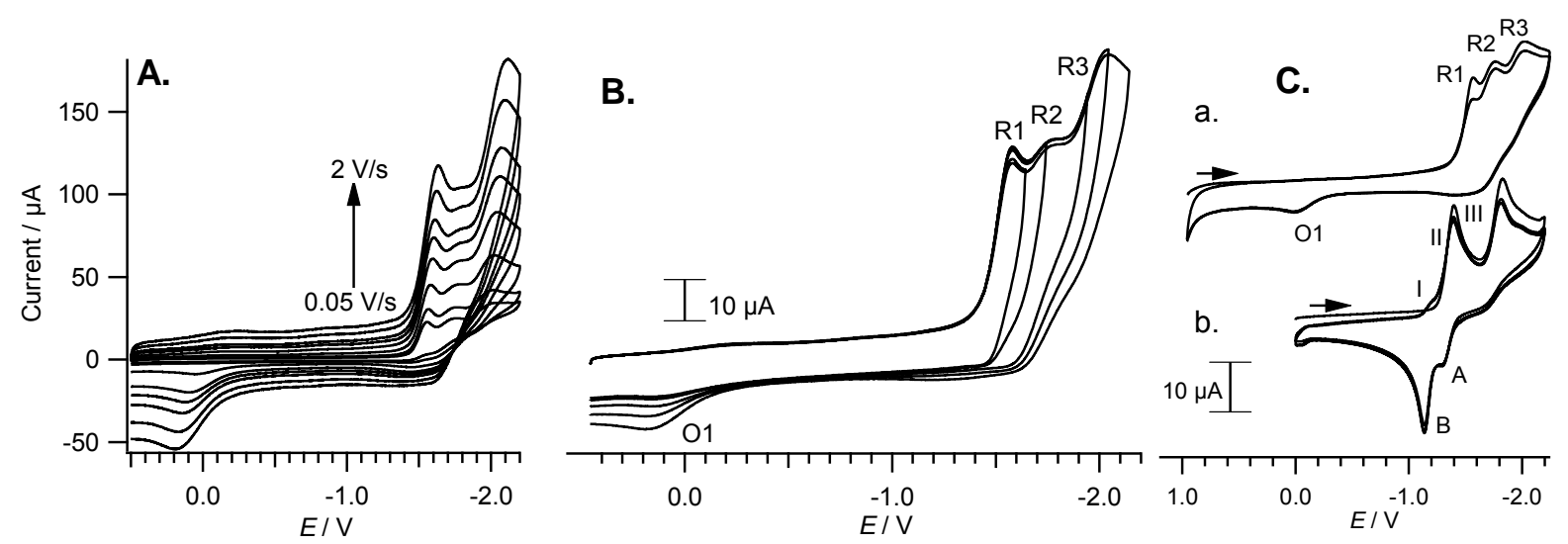

Figure S7. Cyclic voltammograms showing the effect of (A) scan rate $\left(v=0.1,0.25,0.5,0.75\right.$, and $1 \mathrm{~V} \mathrm{~s}^{-}$ $\left.{ }^{1}\right)$ and $(\mathbf{B})$ switching potential $\left(v=0.1 \mathrm{~V} \mathrm{~s}^{-1}\right)$ on the two-electron reduction and re-oxidation of $\left[\mathrm{Re}(4 \mathrm{DHBP})(\mathrm{CO})_{3} \mathrm{Cl}\right](2 \mathrm{mM})$ in DMF. Potentials are referenced to $\mathrm{Ag} / \mathrm{AgCl}(3 \mathrm{M} \mathrm{KCl})$. C: Multi-scan reductive $\mathrm{CV}$ s comparing $\left[\mathrm{Re}(4 \mathrm{DHBP})(\mathrm{CO})_{3} \mathrm{Cl}\right](\mathrm{a})$ and $\left[\mathrm{Re}\left({ }^{t} \mathrm{Bu}{ }_{2} \mathrm{bpy}\right)(\mathrm{CO})_{3} \mathrm{Cl}\right](\mathrm{b})$ 

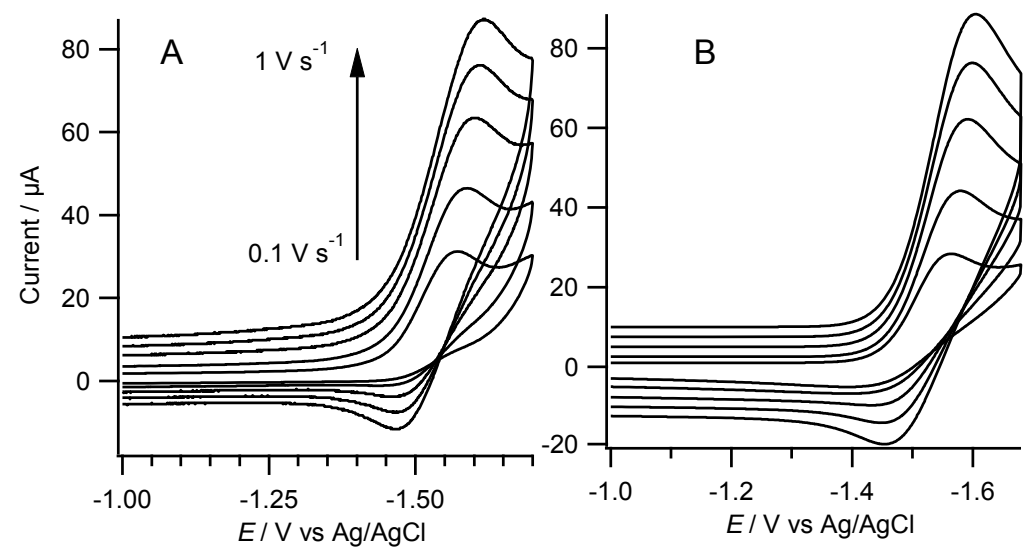

Figure S8. Experimental (A) and simulated (B) cyclic voltammograms for a $2.0 \mathrm{mM}$ $\left[\mathrm{Re}(4 \mathrm{DHBP})(\mathrm{CO})_{3} \mathrm{Cl}\right]$ solution in DMF showing only the first reduction according to the mechanism and parameters given in Scheme 3. Bottom to top: 0.05, 0.1, 0.25, 0.75, and $1 \mathrm{~V} \mathrm{~s}^{-1}$.
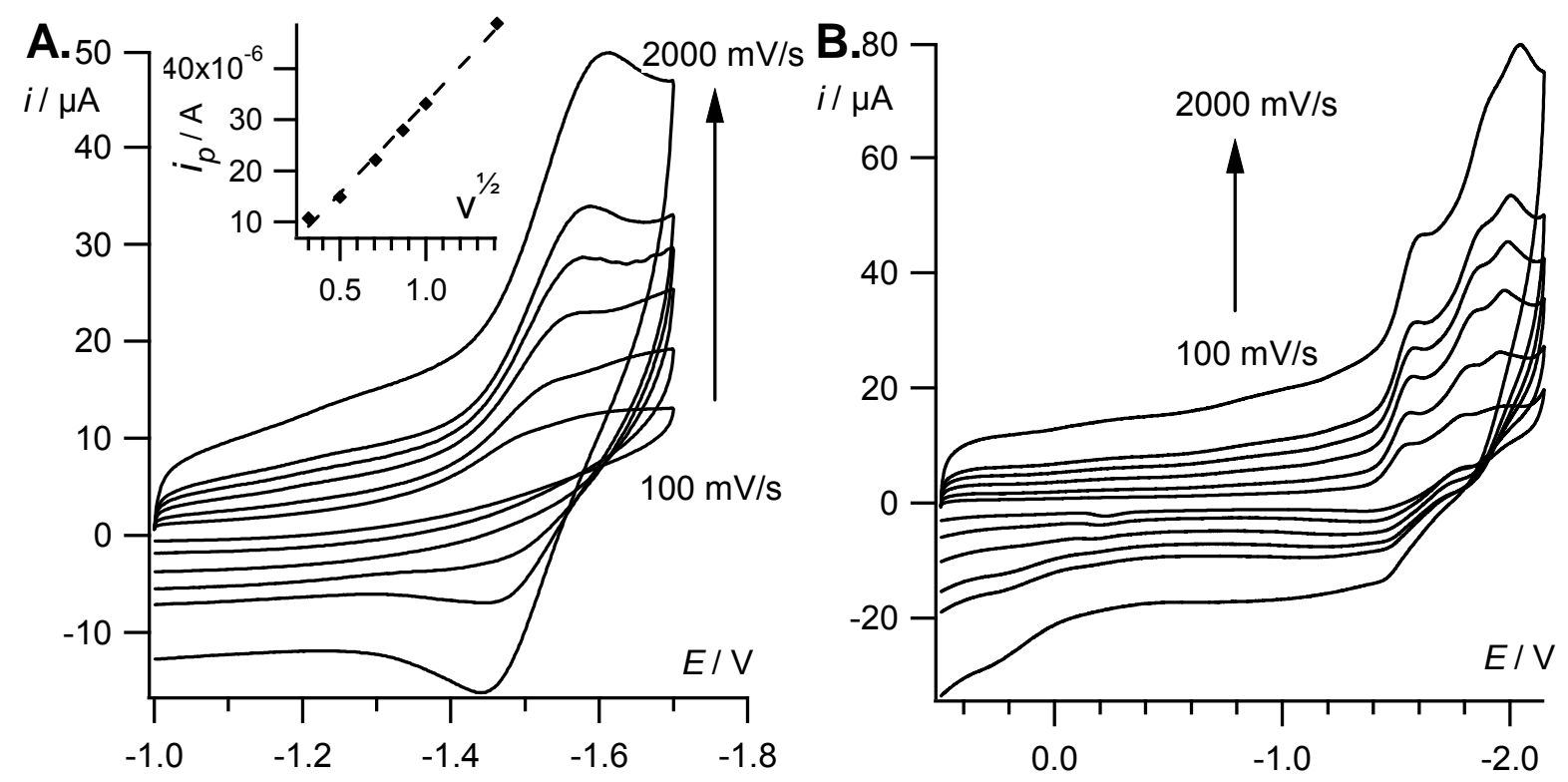

Figure S9. Reductive cyclic voltammograms showing the scan rate dependence of: A: the one-electron and B: the two-electron reduction with $v=0.1,0.25,0.5,0.75,1,2 \mathrm{~V} \mathrm{~s}^{-1},\left[\operatorname{Re}(6 \mathrm{DHBP})(\mathrm{CO})_{3} \mathrm{Cl}\right](1 \mathrm{mM})$ in DMF The inset of (A) shows the dependence of $i_{\mathrm{p}}{ }^{\mathrm{c}}$ for the first reduction on $v^{1 / 2}$. These data were used to calculate the diffusion coefficient, $\mathrm{D}$, from the Randles-Sevcik equation, $i_{p}=$ $0.4463 n \mathrm{~F} A\left[\operatorname{Re}(6 \mathrm{DHBP})(\mathrm{CO})_{3} \mathrm{Cl}\right](n \mathrm{~F} v \mathrm{D} / \mathrm{RT})^{1 / 2}$, as $8.6 \times 10^{-7} \mathrm{~cm}^{2} /$ s. Potentials are referenced to $\mathrm{Ag} / \mathrm{AgCl}$ $(3 \mathrm{M} \mathrm{KCl})$. 


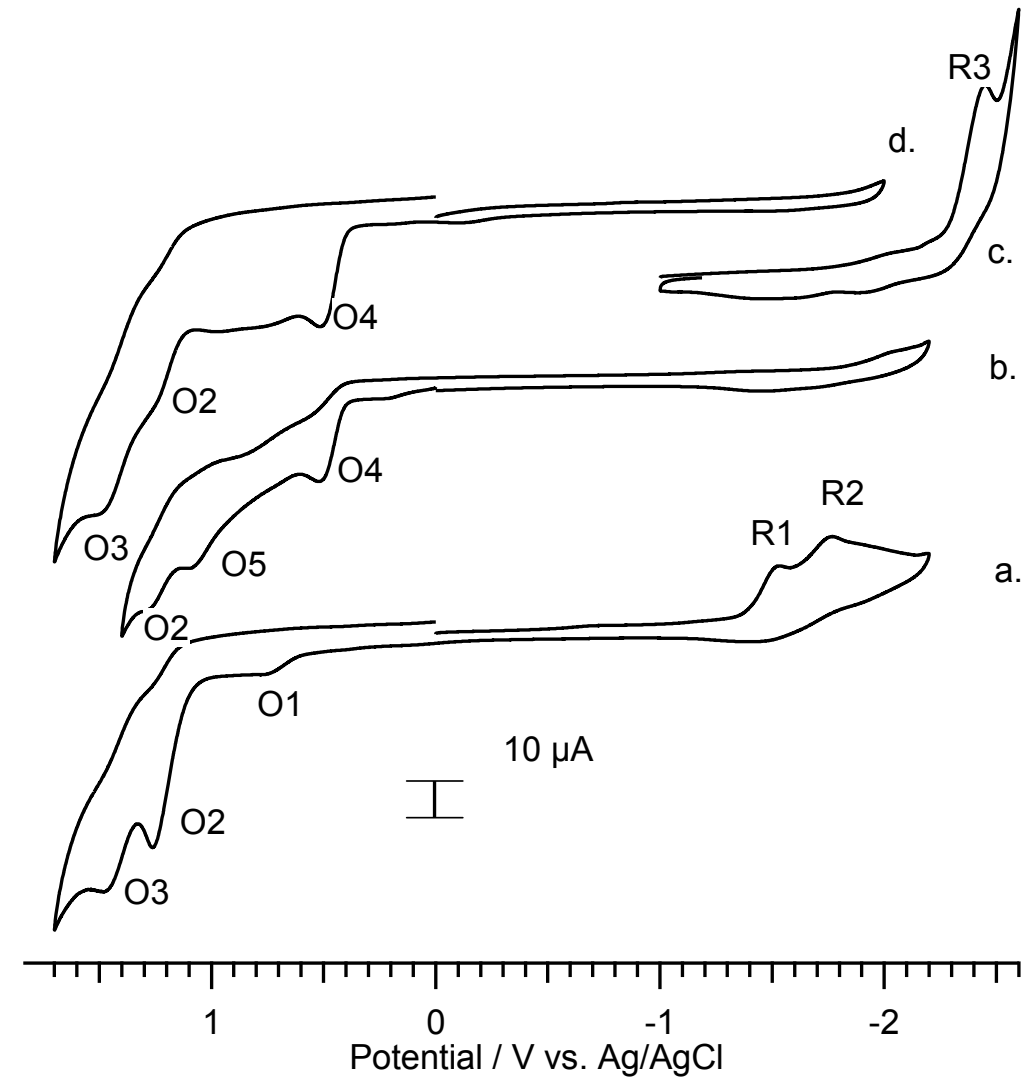

Figure S10. Cyclic voltammetry of $2 \mathrm{mM}\left[\operatorname{Re}(6 \mathrm{DHBP})(\mathrm{CO})_{3} \mathrm{Cl}\right]$ in $\mathrm{DMF}$ with $v=0.1 \mathrm{~V} \mathrm{~s}^{-1}$ (a), after exhaustive $2 \mathrm{e}^{-}$reduction (b), and in the presence of 2 eq. $\mathrm{Bu}_{4} \mathrm{NOH}(\mathbf{c}, \mathbf{d})$. Waves $\mathrm{R} 1$ and $\mathrm{R} 2$ are the twoelectron oxidation according to the proposed mechanism (text Scheme $\mathbf{X}$ ), O1 is re-oxidation of the doubly reduced species, $\mathrm{O} 2$ and $\mathrm{O} 3$ are Re oxidations, $\mathrm{O} 5$ is the $2 \mathrm{Cl}^{-} / \mathrm{Cl}_{2}$ couple, $\mathrm{O} 4$ is oxidation of the phenolate form of the ligand formed after reduction or deprotonation. Potentials are referenced to $\mathrm{Ag} / \mathrm{AgCl}(3 \mathrm{M} \mathrm{KCl})$. 


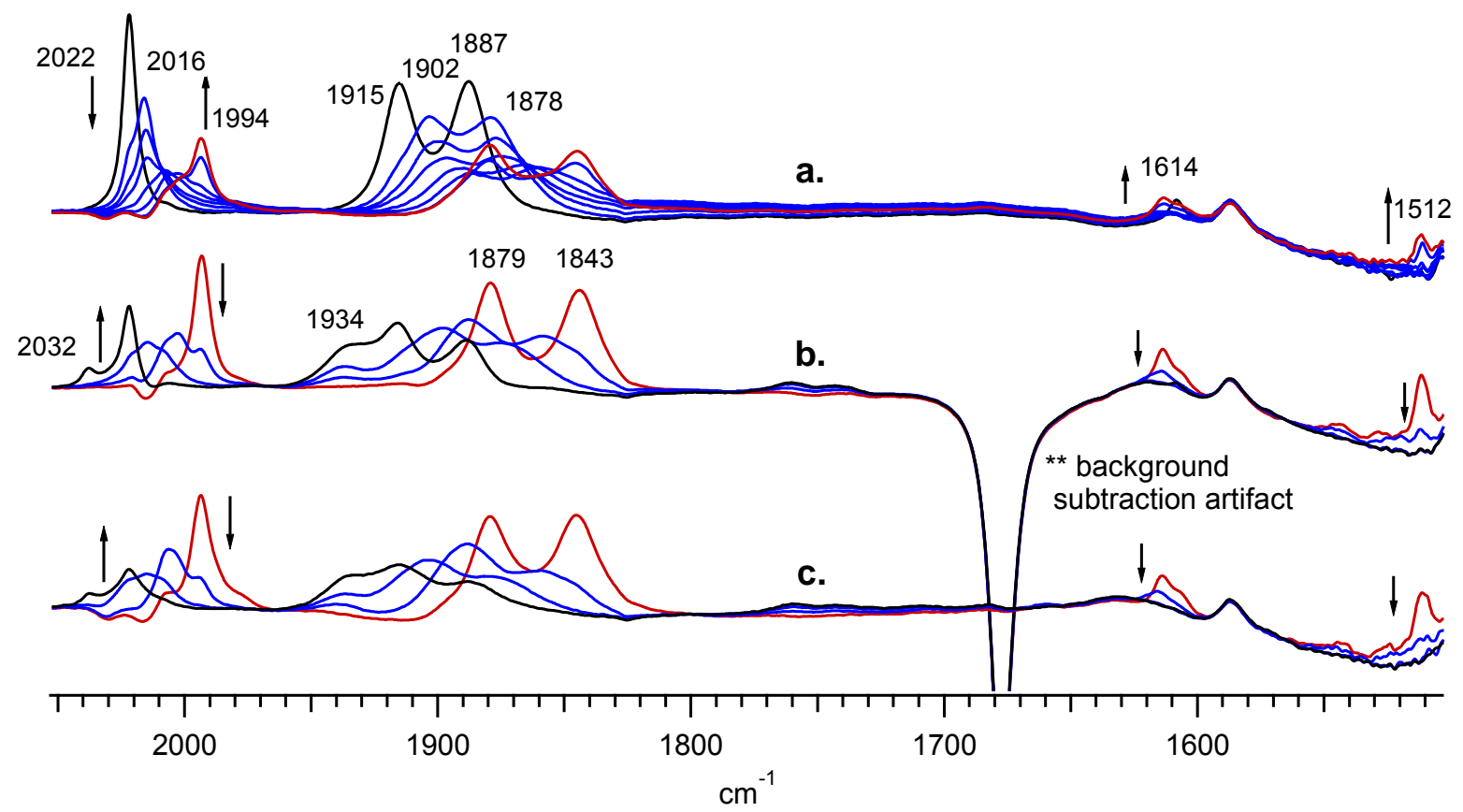

Figure S11. Solution IR in $\mathrm{CH}_{3} \mathrm{CN}$ of $\left[\mathrm{Re}(6 \mathrm{DHBP})(\mathrm{CO})_{3} \mathrm{Cl}\right]$ during electrochemical reduction (a) and reoxidation (b) and upon oxidation of the chemically deprotonated species (c). In (a), the black trace is the initial complex, blue traces are the singly deprotonated complex which is poorly soluble in $\mathrm{CH}_{3} \mathrm{CN}$, and there red trace is $\left[\operatorname{Re}\left(6 \mathrm{DHBP}-2 \mathrm{H}^{+}\right)(\mathrm{CO})_{3}\right]^{-}$. In traces $\mathrm{b}$ and $\mathrm{c}$, the black spectrum is a mixture of $\left[\mathrm{Re}(6 \mathrm{DHBP})(\mathrm{CO})_{3} \mathrm{Cl}\right]$ and $\left[\mathrm{Re}(6 \mathrm{DHBP})(\mathrm{CO})_{3}\left(\mathrm{CH}_{3} \mathrm{CN}\right)\right]^{+}$.

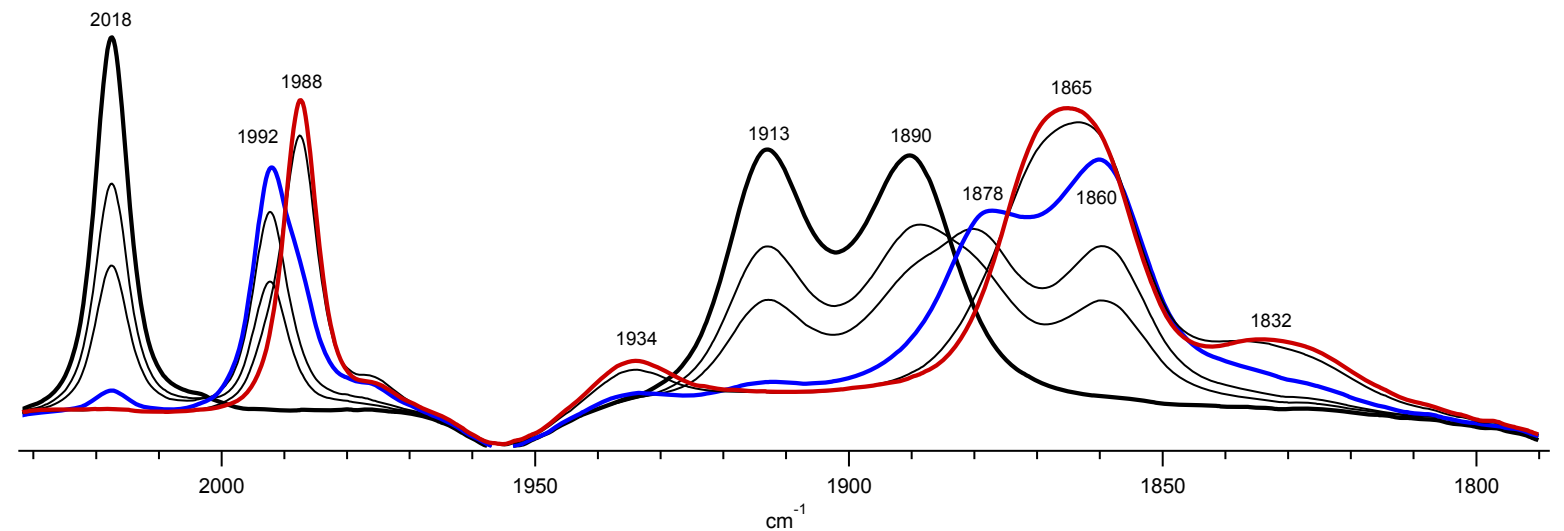

Figure S12. Solution IR in DMF of $\left[\operatorname{Re}\left({ }^{t} \mathrm{Bu} u_{2} \mathrm{bpy}\right)(\mathrm{CO})_{3} \mathrm{Cl}\right]$ (bold, black spectrum) during electrochemical reduction. The bold blue spectrum is $\left[\operatorname{Re}\left({ }^{t} \mathrm{Bu}_{2} \mathrm{bpy}\right)(\mathrm{CO})_{3} \mathrm{Cl}\right]^{-}$. The bold red spectrum contains a mixture of neutral $\left[\operatorname{Re}\left({ }^{t} \mathrm{Bu}_{2} \mathrm{bpy}\right)(\mathrm{CO})_{3}\right]$ and the doubly reduced species $\left[\operatorname{Re}\left({ }^{t} \mathrm{Bu}_{2} \mathrm{bpy}\right)(\mathrm{CO})_{3}\right]^{-}\left(1934,1832 \mathrm{~cm}^{-1}\right)$. 

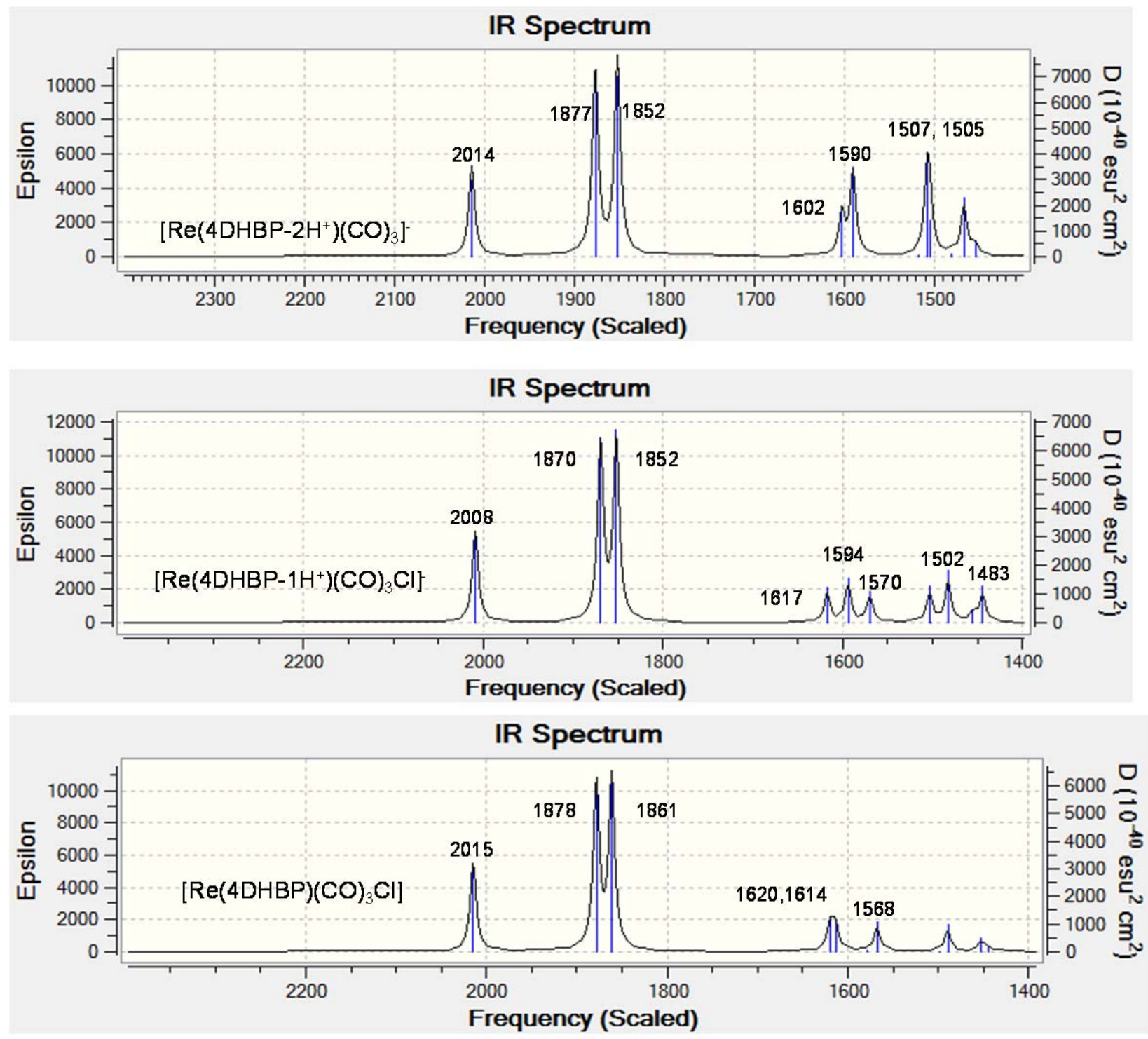

Figure S13. Calculated IR spectra in DMF for species derived from $\left[\operatorname{Re}(4 \mathrm{DHBP})(\mathrm{CO})_{3} \mathrm{Cl}\right]$. Scaling factor $=0.981$. 

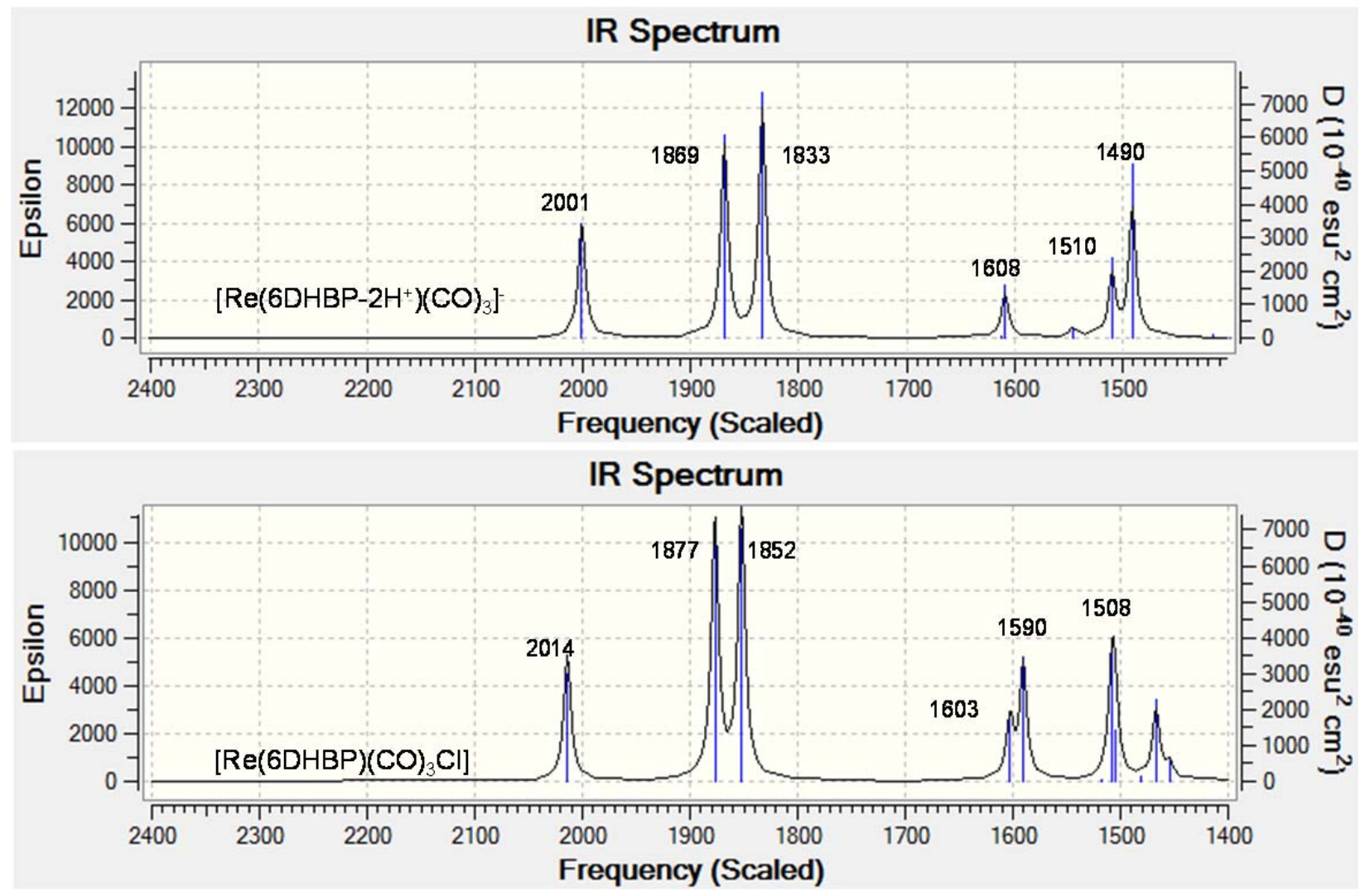

Figure S14. Calculated IR data $(v(C O)$ in $D M F)$ for species derived from $\left[\operatorname{Re}(6 \mathrm{DHBP})(\mathrm{CO}){ }_{3} \mathrm{Cl}\right]$. Scaling factor $=0.981$. 
Table S6. Two-electron reduction free-energy pathway to doubly deprotonated species of $\left[\operatorname{Re}^{\mathrm{I}}(4 \mathrm{DHBP})(\mathrm{CO})_{3}(\mathrm{DMF})\right]^{+}$.

\begin{tabular}{|c|c|c|c|c|c|c|c|}
\hline Species & G*species & Reservoir & G* reservoir & $\overline{G^{*}{ }_{\text {total }}}$ & $\begin{array}{c}\text { Rel. } \Delta \mathrm{G}^{*}{ }_{\text {total }} \\
(\mathrm{eV})\end{array}$ & $\begin{array}{l}\text { Rel. } \Delta G^{*}{ }_{\text {total }} \\
\text { vs. NHE (eV) }\end{array}$ & $\begin{array}{l}G^{*} \text { step vs. } \\
\text { NHE (eV) }\end{array}$ \\
\hline$\left[\operatorname{Re}^{\mathrm{I}}(4 \mathrm{DHBP})(\mathrm{CO})_{3}(\mathrm{~S})\right]^{+}$ & -1313.141971 & $2 \mathrm{H}^{+}, 2 \mathrm{e}^{-}$ & -0.873700 & -1314.014246 & 0.000000 & 0.000000 & \\
\hline & -1064.900773 & $2 \mathrm{H}^{+}, \mathrm{S}$ & -249.332063 & -1314.231411 & -5.909360 & 2.434711 & -0.968807 \\
\hline$\left[\operatorname{Re}^{\mathrm{I}}\left(4 \mathrm{DHBP}+2 \mathrm{H}^{+}\right)(\mathrm{CO})_{3}\right]^{+}$ & -1065.807310 & $\mathrm{~S}$ & -248.461129 & -1314.267014 & -6.878167 & 1.465904 & -0.687196 \\
\hline$\left[\operatorname{Re}^{\mathrm{I}}\left(4 \mathrm{DHBP}-2 \mathrm{H}^{+}\right)(\mathrm{CO})_{3}\right]^{-}$ & -1063.781291 & $2 \mathrm{H}^{+}, \mathrm{H}_{2}, \mathrm{~S}$ & -250.512402 & -1314.292268 & -7.565363 & 0.778708 & \\
\hline
\end{tabular}

Table S7. One-electron reduction free-energy pathway to singly deprotonated species of $\left[\operatorname{Re}^{\mathrm{I}}(4 \mathrm{DHBP})(\mathrm{CO})_{3}(\mathrm{DMF})\right]^{+}$.

\begin{tabular}{|c|c|c|c|c|c|c|c|}
\hline Species & 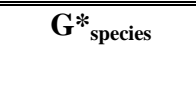 & Reservoir & 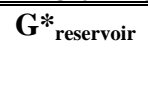 & 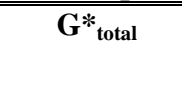 & $\begin{array}{c}\begin{array}{c}\text { Rel. } \Delta G^{*} \text { total } \\
(\mathrm{eV})\end{array}\end{array}$ & $\begin{array}{l}\text { Rel. } \Delta \mathrm{G}^{*} \text { total } \\
\text { vs NHE (eV) }\end{array}$ & $\begin{array}{l}\Delta G^{*}{ }_{\text {step }} \text { vs } \\
\text { NHE (eV) }\end{array}$ \\
\hline$\left[\operatorname{Re}^{\mathrm{I}}(4 \mathrm{DHBP})(\mathrm{CO})_{3}(\mathrm{~S})\right]^{+}$ & -1313.385071 & $\mathrm{H}^{+}, \mathrm{e}$ & .436850 & -1313.821778 & 0.000000 & 0.000000 & \\
\hline${ }^{2}\left[\operatorname{Re}^{\mathrm{I}}(4 \mathrm{DHBP})(\mathrm{CO})_{3}(\mathrm{~S})\right]^{0}$ & -1313.488613 & $2 \mathrm{H}^{+}$ & -0.435467 & -1313.923937 & -2.779899 & 1.392137 & \\
\hline${ }^{2}\left[\operatorname{Re}^{\mathrm{I}}\left(4 \mathrm{DHBP}+\mathrm{H}^{+}\right)(\mathrm{CO})_{3}(\mathrm{~S})\right]^{+}$ & -1313.942883 & -- & -0.000000 & -1313.942741 & -3.291568 & 0.880468 & \\
\hline$\left[\operatorname{Re}^{\mathrm{I}}\left(4 \mathrm{DHBP}-\mathrm{H}^{+}\right)(\mathrm{CO})_{3}(\mathrm{~S})\right]^{0}$ & -1312.921514 & $\mathrm{H}^{+}, 1 / 2 \mathrm{H}_{2}$ & -1.025637 & -1313.947008 & -3.407667 & 0.764369 & -0.11008 \\
\hline
\end{tabular}





Figure S13. Free-energy profiles for two-electron reduction pathway from $\left[\operatorname{Re}^{\mathrm{I}}(4 \mathrm{DHBP})(\mathrm{CO})_{3}(\mathrm{DMF})\right]^{+}$to the doubly deprotonated intermediate $\left[\operatorname{Re}^{\mathrm{I}}\left(4 \mathrm{DHBP}-2 \mathrm{H}^{+}\right)(\mathrm{CO})_{3}\right]$ (top), and to the one-electron reduction pathway to $\left[\operatorname{Re}^{\mathrm{I}}\left(4 \mathrm{DHBP}-\mathrm{H}^{+}\right)(\mathrm{CO})_{3}(\mathrm{DMF})^{0}\right.$ (bottom) in DMF. The latter pathway involves the disproportionation of the $\left[\operatorname{Re}^{\mathrm{I}}\left(4 \mathrm{DHBP}+\mathrm{H}^{+}\right)(\mathrm{CO})^{3}(\mathrm{DMF})\right]^{+}$intermediate. 


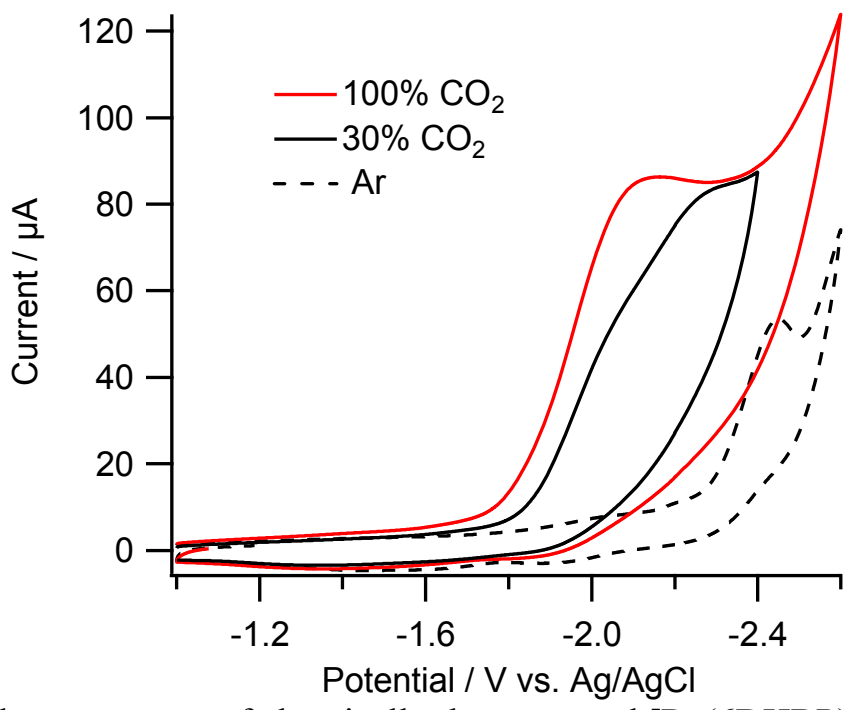

Figure S13. Cyclic voltammograms of chemically deprotonated $\left[\mathrm{Re}(6 \mathrm{DHBP})(\mathrm{CO})_{3} \mathrm{Cl}\right]$ under $\mathrm{Ar}, \mathrm{CO}_{2}$, or a $30 \% \mathrm{CO}_{2}$ in $\mathrm{N}_{2}$ mixture. The peak current independence on $\left[\mathrm{CO}_{2}\right]$ illustrates that this is not a catalytic current.

Table S8. Calculated structure of $\left[\mathrm{Re}(4 \mathrm{DHBP})(\mathrm{CO}){ }_{3} \mathrm{Cl}\right]$.

Energy: -957108.4405093

$\begin{array}{lrrr}\mathrm{C} & -1.79620 & -0.74103 & 0.05040 \\ \mathrm{~N} & -0.57116 & -1.33487 & 0.08019 \\ \mathrm{C} & -0.51454 & -2.68297 & 0.09549 \\ \mathrm{C} & -1.63734 & -3.49536 & 0.07906 \\ \mathrm{C} & -2.89993 & -2.88525 & 0.04427 \\ \mathrm{C} & -2.97115 & -1.48592 & 0.03105 \\ \mathrm{Re} & 1.19440 & -0.00001 & 0.05192 \\ \mathrm{~N} & -0.57115 & 1.33487 & 0.08017 \\ \mathrm{C} & -0.51451 & 2.68297 & 0.09545 \\ \mathrm{C} & -1.63731 & 3.49538 & 0.07901 \\ \mathrm{C} & -2.89990 & 2.88528 & 0.04423 \\ \mathrm{C} & -2.97113 & 1.48595 & 0.03103 \\ \mathrm{C} & -1.79619 & 0.74104 & 0.05039 \\ \mathrm{C} & 2.56319 & 1.35570 & -0.08662 \\ \mathrm{O} & 3.37995 & 2.18320 & -0.17428 \\ \mathrm{C} & 1.34842 & -0.00003 & 1.95539 \\ \mathrm{O} & 1.44661 & 0.00018 & 3.12082 \\ \mathrm{C} & 2.56317 & -1.35574 & -0.08661 \\ \mathrm{O} & 3.37992 & -2.18325 & -0.17420 \\ \mathrm{H} & -1.53267 & 4.58387 & 0.09279 \\ \mathrm{H} & -3.94985 & 1.00328 & 0.00682 \\ \mathrm{H} & -3.94986 & -1.00324 & 0.00683 \\ \mathrm{H} & -1.53272 & -4.58385 & 0.09285 \\ \mathrm{Cl} & 0.84618 & -0.00005 & -2.49418 \\ \mathrm{H} & 0.47864 & -3.12653 & 0.12199 \\ \mathrm{H} & 0.47868 & 3.12652 & 0.12194 \\ \mathrm{O} & -4.05470 & 3.57236 & 0.02473 \\ \mathrm{H} & -3.87849 & 4.56843 & 0.03584 \\ \mathrm{O} & -4.05474 & -3.57232 & 0.02477 \\ \mathrm{H} & -3.87854 & -4.56839 & 0.03590\end{array}$


Table S9. Calculated structure of $\left[\mathrm{Re}(6 \mathrm{DHBP})(\mathrm{CO})_{3} \mathrm{Cl}\right]$.

$\begin{array}{lrrr}\text { Energy: }-957105.7030055 & \\ \text { C } & -2.14797 & -0.70672 & 0.03962 \\ \mathrm{~N} & -0.93749 & -1.33357 & 0.13924 \\ \mathrm{C} & -0.91337 & -2.67802 & 0.21805 \\ \mathrm{C} & -2.07929 & -3.46096 & 0.16490 \\ \mathrm{C} & -3.29916 & -2.82099 & 0.03505 \\ \mathrm{C} & -3.34023 & -1.42459 & -0.02194 \\ \mathrm{Re} & 0.87579 & -0.01399 & 0.01721 \\ \mathrm{~N} & -0.89541 & 1.36162 & 0.13559 \\ \mathrm{C} & -0.82772 & 2.70453 & 0.21387 \\ \mathrm{C} & -1.96689 & 3.52657 & 0.16326 \\ \mathrm{C} & -3.20688 & 2.92472 & 0.03729 \\ \mathrm{C} & -3.29304 & 1.53012 & -0.01861 \\ \mathrm{C} & -2.12479 & 0.77356 & 0.03941 \\ \mathrm{C} & 2.27695 & 1.28713 & -0.21853 \\ \mathrm{O} & 3.15305 & 2.03996 & -0.37345 \\ \mathrm{C} & 1.15545 & -0.01199 & 1.90531 \\ \mathrm{O} & 1.33440 & -0.00980 & 3.06177 \\ \mathrm{C} & 2.23741 & -1.35763 & -0.21059 \\ \mathrm{O} & 3.09141 & -2.13661 & -0.35990 \\ \mathrm{H} & -1.84697 & 4.61142 & 0.22450 \\ \mathrm{H} & -4.26415 & 1.05081 & -0.10016 \\ \mathrm{H} & -4.29481 & -0.91382 & -0.10708 \\ \mathrm{H} & -1.99409 & -4.54911 & 0.22705 \\ \mathrm{H} & -4.22162 & -3.39937 & -0.01331 \\ \mathrm{H} & -4.11119 & 3.53133 & -0.00871 \\ \mathrm{Cl} & 0.36617 & -0.01139 & -2.50126 \\ \mathrm{O} & 0.40243 & 3.21429 & 0.34710 \\ \mathrm{H} & 0.36634 & 4.22544 & 0.37875 \\ \mathrm{O} & 0.29836 & -3.23089 & 0.35404 \\ \mathrm{H} & 0.22728 & -4.23990 & 0.38696\end{array}$


Table S10. Calculated structure of $\left[\mathrm{Re}\left(4 \mathrm{DHBP}-2 \mathrm{H}^{+}\right)(\mathrm{CO})_{3}\right]^{-}$.

Energy: -667617.1127964

$\begin{array}{lccc}\mathrm{C} & 1.78445 & 0.74316 & -0.05287 \\ \mathrm{~N} & 0.53912 & 1.32259 & -0.06356 \\ \mathrm{C} & 0.48300 & 2.68497 & -0.04831 \\ \mathrm{C} & 1.58984 & 3.49979 & -0.03046 \\ \mathrm{C} & 2.91239 & 2.93420 & -0.02693 \\ \mathrm{C} & 2.94304 & 1.49571 & -0.03712 \\ \mathrm{Re} & -1.17762 & 0.00186 & -0.15627 \\ \mathrm{~N} & 0.53840 & -1.32200 & -0.07371 \\ \mathrm{C} & 0.48162 & -2.68426 & -0.05973 \\ \mathrm{C} & 1.58811 & -3.49952 & -0.03376 \\ \mathrm{C} & 2.91085 & -2.93454 & -0.01927 \\ \mathrm{C} & 2.94216 & -1.49616 & -0.02899 \\ \mathrm{C} & 1.78386 & -0.74326 & -0.05360 \\ \mathrm{C} & -2.52123 & -1.35683 & -0.50613 \\ \mathrm{O} & -3.32433 & -2.17493 & -0.71798 \\ \mathrm{C} & -1.67622 & -0.01957 & 1.64671 \\ \mathrm{O} & -1.94838 & -0.03270 & 2.78713 \\ \mathrm{C} & -2.51923 & 1.37023 & -0.47030 \\ \mathrm{O} & -3.32206 & 2.19493 & -0.65638 \\ \mathrm{H} & 1.46184 & -4.58510 & -0.02367 \\ \mathrm{H} & 3.91711 & -1.00573 & -0.01461 \\ \mathrm{H} & 3.91799 & 1.00511 & -0.03176 \\ \mathrm{H} & 1.46380 & 4.58539 & -0.01926 \\ \mathrm{H} & -0.51606 & 3.11729 & -0.04865 \\ \mathrm{H} & -0.51773 & -3.11596 & -0.06808 \\ \mathrm{O} & 3.97367 & -3.64405 & 0.00261 \\ \mathrm{O} & 3.97562 & 3.64318 & -0.01393\end{array}$


Table S11. Calculated structure of $\left[\mathrm{Re}\left(4 \mathrm{DHBP}-1 \mathrm{H}^{+}\right)(\mathrm{CO})_{3} \mathrm{Cl}\right]^{-}$.

\begin{tabular}{lrrr}
\multicolumn{4}{l}{ Energy: -956815.6609188} \\
$\mathrm{C}$ & -1.86114 & -0.59183 & 0.05564 \\
$\mathrm{~N}$ & -0.67938 & -1.26814 & 0.10426 \\
$\mathrm{C}$ & -0.70940 & -2.61740 & 0.13678 \\
$\mathrm{C}$ & -1.88088 & -3.35495 & 0.11409 \\
$\mathrm{C}$ & -3.10071 & -2.66420 & 0.04826 \\
$\mathrm{C}$ & -3.08137 & -1.26469 & 0.02450 \\
$\mathrm{Re}$ & 1.17195 & -0.06060 & 0.05463 \\
$\mathrm{~N}$ & -0.48600 & 1.38665 & 0.07335 \\
$\mathrm{C}$ & -0.34514 & 2.73578 & 0.08779 \\
$\mathrm{C}$ & -1.40204 & 3.62212 & 0.07371 \\
$\mathrm{C}$ & -2.75025 & 3.14062 & 0.04187 \\
$\mathrm{C}$ & -2.87398 & 1.71285 & 0.03067 \\
$\mathrm{C}$ & -1.75938 & 0.88965 & 0.04805 \\
$\mathrm{C}$ & 2.63108 & 1.19210 & -0.11366 \\
$\mathrm{O}$ & 3.50550 & 1.95752 & -0.21962 \\
$\mathrm{C}$ & 1.34374 & -0.04830 & 1.95327 \\
$\mathrm{O}$ & 1.45468 & -0.04231 & 3.11883 \\
$\mathrm{C}$ & 2.43772 & -1.51465 & -0.07994 \\
$\mathrm{O}$ & 3.19136 & -2.40220 & -0.16433 \\
$\mathrm{H}$ & -1.20703 & 4.69670 & 0.08753 \\
$\mathrm{H}$ & -3.87760 & 1.28571 & 0.01203 \\
$\mathrm{H}$ & -4.02471 & -0.71830 & -0.01979 \\
$\mathrm{H}$ & -1.84844 & -4.44754 & 0.14111 \\
$\mathrm{Cl}$ & 0.82102 & -0.08267 & -2.50456 \\
$\mathrm{H}$ & 0.25301 & -3.12273 & 0.18164 \\
$\mathrm{H}$ & 0.67821 & 3.10587 & 0.11222 \\
$\mathrm{O}$ & -3.77707 & 3.91665 & 0.02785 \\
$\mathrm{O}$ & -4.29683 & -3.28172 & 0.00795 \\
$\mathrm{H}$ & -4.18014 & -4.28507 & 0.03061 \\
& & & \\
& & &
\end{tabular}


Table S12. Calculated structure of $\left[\operatorname{Re}\left(4 \mathrm{DHBP}-1 \mathrm{H}^{+}\right)(\mathrm{CO})_{3}(\mathrm{DMF})\right]$.

$\begin{array}{lccc}\text { Energy: }-823887.5998571 & \\ \mathrm{C} & 2.02809 & -0.64058 & 0.20118 \\ \mathrm{~N} & 0.91202 & -1.27979 & -0.25057 \\ \mathrm{C} & 0.91034 & -2.63006 & -0.28424 \\ \mathrm{C} & 1.98629 & -3.40385 & 0.11492 \\ \mathrm{C} & 3.13997 & -2.75064 & 0.57696 \\ \mathrm{C} & 3.15132 & -1.35099 & 0.61853 \\ \mathrm{Re} & -0.79197 & -0.01251 & -0.86077 \\ \mathrm{~N} & 0.79784 & 1.37715 & -0.26812 \\ \mathrm{C} & 0.70200 & 2.73241 & -0.29555 \\ \mathrm{C} & 1.69740 & 3.58471 & 0.12840 \\ \mathrm{C} & 2.93492 & 3.06624 & 0.64223 \\ \mathrm{C} & 3.01294 & 1.62963 & 0.65325 \\ \mathrm{C} & 1.96588 & 0.84297 & 0.20643 \\ \mathrm{C} & -2.16533 & 1.29164 & -1.24225 \\ \mathrm{O} & -2.98513 & 2.08732 & -1.47817 \\ \mathrm{C} & -0.28853 & -0.01859 & -2.70238 \\ \mathrm{O} & 0.02151 & -0.02190 & -3.82909 \\ \mathrm{C} & -2.07163 & -1.42232 & -1.20891 \\ \mathrm{O} & -2.83202 & -2.28070 & -1.42660 \\ \mathrm{H} & 1.54339 & 4.66476 & 0.07458 \\ \mathrm{H} & 3.92940 & 1.17066 & 1.02730 \\ \mathrm{H} & 4.04371 & -0.83486 & 0.97587 \\ \mathrm{H} & 1.93304 & -4.49488 & 0.06562 \\ \mathrm{O} & -1.15687 & 0.01401 & 1.34390 \\ \mathrm{C} & -2.27199 & -0.11742 & 1.92625 \\ \mathrm{H} & -3.19923 & -0.26095 & 1.34931 \\ \mathrm{~N} & -2.42335 & -0.09406 & 3.24230 \\ \mathrm{C} & -3.74901 & -0.25380 & 3.84651 \\ \mathrm{H} & -4.50033 & -0.38142 & 3.05799 \\ \mathrm{H} & -3.75006 & -1.13670 & 4.50131 \\ \mathrm{H} & -3.99041 & 0.63729 & 4.44314 \\ \mathrm{C} & -1.29797 & 0.08833 & 4.16149 \\ \mathrm{H} & -0.37120 & 0.19921 & 3.59285 \\ \mathrm{H} & -1.22691 & -0.78603 & 4.82428 \\ \mathrm{H} & -1.47127 & 0.98667 & 4.77113 \\ \mathrm{H} & 0.00288 & -3.10487 & -0.65145 \\ \mathrm{H} & -0.23288 & 3.13361 & -0.68273 \\ \mathrm{O} & 4.24436 & -3.40298 & 0.98337 \\ \mathrm{O} & 3.89019 & 3.80912 & 1.05429 \\ \mathrm{H} & 4.11754 & -4.40282 & 0.90443\end{array}$


Table S13. Calculated structure of $\left[\operatorname{Re}\left(4 \mathrm{DHBP}-1 \mathrm{H}^{+}\right)(\mathrm{CO})_{3}\right]$.

\begin{tabular}{lrrr}
\multicolumn{4}{l}{ Energy: -667909.8629315} \\
$\mathrm{C}$ & -1.82112 & -0.56796 & -0.05554 \\
$\mathrm{~N}$ & -0.64738 & -1.26618 & -0.03755 \\
$\mathrm{C}$ & -0.70044 & -2.61812 & -0.01977 \\
$\mathrm{C}$ & -1.88452 & -3.33248 & -0.02206 \\
$\mathrm{C}$ & -3.09410 & -2.61898 & -0.04610 \\
$\mathrm{C}$ & -3.05085 & -1.21813 & -0.05911 \\
$\mathrm{Re}$ & 1.19834 & -0.09362 & -0.16542 \\
$\mathrm{~N}$ & -0.39875 & 1.37418 & -0.14794 \\
$\mathrm{C}$ & -0.22292 & 2.72602 & -0.14695 \\
$\mathrm{C}$ & -1.25130 & 3.63517 & -0.07582 \\
$\mathrm{C}$ & -2.61681 & 3.19115 & 0.00887 \\
$\mathrm{C}$ & -2.77569 & 1.75822 & 0.00268 \\
$\mathrm{C}$ & -1.68862 & 0.91032 & -0.07032 \\
$\mathrm{C}$ & 2.65767 & 1.13610 & -0.52296 \\
$\mathrm{O}$ & 3.52831 & 1.87767 & -0.73887 \\
$\mathrm{C}$ & 1.64410 & -0.05260 & 1.65268 \\
$\mathrm{O}$ & 1.88866 & -0.01976 & 2.79716 \\
$\mathrm{C}$ & 2.43616 & -1.57672 & -0.39094 \\
$\mathrm{O}$ & 3.17624 & -2.46653 & -0.52105 \\
$\mathrm{H}$ & -1.02899 & 4.70461 & -0.07622 \\
$\mathrm{H}$ & -3.78821 & 1.35662 & 0.06942 \\
$\mathrm{H}$ & -3.98533 & -0.65466 & -0.07933 \\
$\mathrm{H}$ & -1.87178 & -4.42588 & -0.01008 \\
$\mathrm{H}$ & 0.25349 & -3.14077 & -0.00148 \\
$\mathrm{H}$ & 0.80850 & 3.06879 & -0.20259 \\
$\mathrm{O}$ & -3.60884 & 3.98740 & 0.08739 \\
$\mathrm{O}$ & -4.29968 & -3.21088 & -0.05891 \\
$\mathrm{H}$ & -4.20731 & -4.21840 & -0.04893
\end{tabular}


Table S14. Calculated structure of $\left[\operatorname{Re}\left(6 \mathrm{DHBP}-2 \mathrm{H}^{+}\right)(\mathrm{CO})_{3}\right]^{-}$.

\begin{tabular}{lccc}
\multicolumn{4}{l}{ Energy: -667616.8372193} \\
$\mathrm{C}$ & 2.10608 & 0.74240 & -0.08268 \\
$\mathrm{~N}$ & 0.86925 & 1.33724 & -0.02347 \\
$\mathrm{C}$ & 0.75699 & 2.72733 & 0.06660 \\
$\mathrm{C}$ & 1.97168 & 3.50236 & 0.02081 \\
$\mathrm{C}$ & 3.19741 & 2.88816 & -0.06514 \\
$\mathrm{C}$ & 3.27939 & 1.48102 & -0.11089 \\
$\mathrm{Re}$ & -0.85343 & -0.00034 & -0.15510 \\
$\mathrm{~N}$ & 0.87023 & -1.33665 & -0.02351 \\
$\mathrm{C}$ & 0.75902 & -2.72683 & 0.06654 \\
$\mathrm{C}$ & 1.97432 & -3.50094 & 0.02090 \\
$\mathrm{C}$ & 3.19958 & -2.88582 & -0.06499 \\
$\mathrm{C}$ & 3.28050 & -1.47862 & -0.11079 \\
$\mathrm{C}$ & 2.10663 & -0.74088 & -0.08267 \\
$\mathrm{C}$ & -2.18980 & -1.34808 & -0.56546 \\
$\mathrm{O}$ & -3.03962 & -2.10192 & -0.83250 \\
$\mathrm{C}$ & -1.47387 & -0.00032 & 1.60693 \\
$\mathrm{O}$ & -1.83481 & -0.00043 & 2.72581 \\
$\mathrm{C}$ & -2.19071 & 1.34643 & -0.56569 \\
$\mathrm{O}$ & -3.04101 & 2.09978 & -0.83259 \\
$\mathrm{H}$ & 1.87685 & -4.58727 & 0.07267 \\
$\mathrm{H}$ & 4.24778 & -0.98833 & -0.15927 \\
$\mathrm{H}$ & 4.24705 & 0.99148 & -0.15943 \\
$\mathrm{H}$ & 1.87340 & 4.58863 & 0.07253 \\
$\mathrm{H}$ & 4.11181 & 3.48312 & -0.08799 \\
$\mathrm{H}$ & 4.11443 & -3.48009 & -0.08772 \\
$\mathrm{O}$ & -0.37256 & -3.27524 & 0.18899 \\
$\mathrm{O}$ & -0.37501 & 3.27489 & 0.18905
\end{tabular}


Table S15. Calculated structure of ${ }^{1}\left[\operatorname{Re}(4 \mathrm{DHBP})(\mathrm{CO})_{3}(\mathrm{DMF})\right]^{1+}$.

$\begin{array}{cccc}\mathrm{C} & 1.994571 & -0.725277 & 0.229943 \\ \mathrm{~N} & 0.855206 & -1.343714 & -0.187315 \\ \mathrm{C} & 0.804438 & -2.690064 & -0.154678 \\ \mathrm{C} & 1.853269 & -3.481108 & 0.285504 \\ \mathrm{C} & 3.022382 & -2.846550 & 0.720309 \\ \mathrm{C} & 3.090241 & -1.449367 & 0.689149 \\ \mathrm{Re} & -0.811390 & -0.052989 & -0.847473 \\ \mathrm{~N} & 0.838368 & 1.315896 & -0.317983 \\ \mathrm{C} & 0.770059 & 2.658162 & -0.415678 \\ \mathrm{C} & 1.811776 & 3.501370 & -0.064150 \\ \mathrm{C} & 2.994138 & 2.926650 & 0.415744 \\ \mathrm{C} & 3.078060 & 1.534227 & 0.524405 \\ \mathrm{C} & 1.987009 & 0.755620 & 0.152004 \\ \mathrm{C} & -2.154382 & 1.266046 & -1.281108 \\ \mathrm{O} & -2.964578 & 2.059213 & -1.548147 \\ \mathrm{C} & -0.306024 & -0.144456 & -2.690623 \\ \mathrm{O} & 0.004441 & -0.200750 & -3.813075 \\ \mathrm{C} & -2.138567 & -1.425890 & -1.145311 \\ \mathrm{O} & -2.939429 & -2.252494 & -1.325150 \\ \mathrm{H} & 1.697931 & 4.576176 & -0.166096 \\ \mathrm{H} & 3.993256 & 1.089784 & 0.893572 \\ \mathrm{H} & 3.994527 & -0.958983 & 1.026118 \\ \mathrm{H} & 1.755343 & -4.562272 & 0.287260 \\ \mathrm{O} & -1.162870 & 0.072999 & 1.333087 \\ \mathrm{C} & -2.288958 & 0.080199 & 1.908583 \\ \mathrm{H} & -3.216700 & -0.000602 & 1.334435 \\ \mathrm{~N} & -2.437963 & 0.182833 & 3.220346 \\ \mathrm{C} & -3.767815 & 0.175935 & 3.830034 \\ \mathrm{H} & -4.531445 & 0.084604 & 3.055632 \\ \mathrm{H} & -3.851192 & -0.668645 & 4.521455 \\ \mathrm{H} & -3.923035 & 1.106738 & 4.384553 \\ \mathrm{C} & -1.297966 & 0.307910 & 4.127211 \\ \mathrm{H} & -0.370651 & 0.286559 & 3.557206 \\ \mathrm{H} & -1.310103 & -0.519715 & 4.843628 \\ \mathrm{H} & -1.372613 & 1.252142 & 4.676232 \\ \mathrm{H} & -0.113568 & -3.150522 & -0.498232 \\ \mathrm{H} & -0.157507 & 3.071843 & -0.790960 \\ \mathrm{O} & 4.102867 & -3.514231 & 1.172834 \\ \mathrm{O} & 4.072790 & 3.647410 & 0.783886 \\ & 3.946854 & -4.474046 & 1.147576 \\ & 3.904705 & 4.598386 & 0.667230\end{array}$


Table S16. Calculated structure of ${ }^{1}\left[\operatorname{Re}\left(4 \mathrm{DHBP}^{2-}\right)(\mathrm{CO})_{3}\right]^{1-}$.

$\begin{array}{rrrr}\mathrm{C} & -1.769810 & 0.703373 & -0.065073 \\ \mathrm{~N} & -0.497680 & 1.303318 & -0.103707 \\ \mathrm{C} & -0.460009 & 2.677326 & -0.091949 \\ \mathrm{C} & -1.565058 & 3.483536 & -0.061170 \\ \mathrm{C} & -2.859098 & 2.874976 & -0.032397 \\ \mathrm{C} & -2.952014 & 1.509357 & -0.031518 \\ \mathrm{Re} & 1.215822 & 0.023277 & -0.077958 \\ \mathrm{~N} & -0.485529 & -1.288324 & -0.118120 \\ \mathrm{C} & -0.420591 & -2.657019 & -0.106728 \\ \mathrm{C} & -1.511915 & -3.484350 & -0.060870 \\ \mathrm{C} & -2.812777 & -2.895108 & -0.012958 \\ \mathrm{C} & -2.929552 & -1.530396 & -0.013933 \\ \mathrm{C} & -1.760829 & -0.705904 & -0.066424 \\ \mathrm{C} & 1.810538 & -0.228974 & 1.699014 \\ \mathrm{O} & 2.229261 & -0.392628 & 2.792540 \\ \mathrm{C} & 2.461947 & -1.253702 & -0.813174 \\ \mathrm{O} & 3.223057 & -2.037453 & -1.260181 \\ \mathrm{C} & 2.499546 & 1.431977 & -0.392356 \\ \mathrm{O} & 3.285182 & 2.294604 & -0.565994 \\ \mathrm{H} & -1.378436 & -4.562239 & -0.058970 \\ \mathrm{H} & -3.913065 & -1.076549 & 0.033729 \\ \mathrm{H} & -3.928486 & 1.038462 & -0.005898 \\ \mathrm{H} & -1.448728 & 4.563508 & -0.061326 \\ \mathrm{H} & 0.529248 & 3.119594 & -0.111470 \\ \mathrm{H} & 0.577720 & -3.079027 & -0.135416 \\ \mathrm{O} & -3.943220 & -3.670830 & 0.039178 \\ \mathrm{H} & -3.694320 & -4.607937 & 0.040574 \\ \mathrm{O} & -4.002217 & 3.634764 & -0.004899 \\ \mathrm{H} & -3.766931 & 4.575287 & -0.009556\end{array}$


Table S17. Calculated structure of ${ }^{1}\left[\operatorname{Re}\left(4 \mathrm{DHBP}+2 \mathrm{H}^{+}\right)(\mathrm{CO})_{3}\right]^{1+}$.

$\begin{array}{crrc}\mathrm{C} & -1.756716 & -0.689860 & -0.060762 \\ \mathrm{~N} & -0.494304 & -1.337943 & 0.021203 \\ \mathrm{C} & -0.422679 & -2.626317 & 0.128391 \\ \mathrm{C} & -2.881525 & -2.848910 & -0.040356 \\ \mathrm{C} & -2.949369 & -1.504606 & -0.138401 \\ \mathrm{Re} & 1.260369 & -0.003815 & -0.218687 \\ \mathrm{~N} & -0.493167 & 1.337367 & 0.009380 \\ \mathrm{C} & -0.419124 & 2.626842 & 0.099278 \\ \mathrm{C} & -2.880775 & 2.849362 & -0.027314 \\ \mathrm{C} & -2.951013 & 1.503937 & -0.107198 \\ \mathrm{C} & -1.756712 & 0.689709 & -0.055964 \\ \mathrm{C} & 2.623797 & 1.343446 & -0.492385 \\ \mathrm{O} & 3.449378 & 2.152091 & -0.625656 \\ \mathrm{C} & 1.669399 & 0.018367 & 1.613627 \\ \mathrm{O} & 1.896864 & 0.033466 & 2.759002 \\ \mathrm{C} & 2.628444 & -1.352392 & -0.459929 \\ \mathrm{O} & 3.458929 & -2.159003 & -0.573963 \\ \mathrm{H} & -3.919679 & 1.031208 & -0.211231 \\ \mathrm{H} & -3.912585 & -1.033214 & -0.289493 \\ \mathrm{H} & 0.566366 & -3.069284 & 0.190452 \\ \mathrm{H} & 0.570921 & 3.069211 & 0.147167 \\ \mathrm{C} & -1.585136 & -3.559485 & 0.178351 \\ \mathrm{H} & -1.429044 & -4.349242 & -0.574056 \\ \mathrm{H} & -1.578185 & -4.083899 & 1.148895 \\ \mathrm{C} & -1.579217 & 3.563050 & 0.144348 \\ \mathrm{H} & -1.552347 & 4.114519 & 1.099361 \\ \mathrm{H} & -1.436431 & 4.331343 & -0.632722 \\ \mathrm{O} & -4.010970 & -3.594914 & -0.131976 \\ \mathrm{H} & -3.803173 & -4.540531 & -0.055605 \\ \mathrm{O} & -4.013309 & 3.593526 & -0.089868 \\ \mathrm{H} & -3.804596 & 4.539852 & -0.025747\end{array}$


Table S18. Calculated structure of ${ }^{1}\left[\operatorname{Re}\left(4 \mathrm{DHBP}-2 \mathrm{H}^{+}\right)(\mathrm{CO})_{3}\right]^{1-}$.

$\begin{array}{crrc}\mathrm{C} & -1.776021 & 0.744735 & -0.097592 \\ \mathrm{~N} & -0.531230 & 1.322159 & -0.205843 \\ \mathrm{C} & -0.474397 & 2.685077 & -0.218694 \\ \mathrm{C} & -1.572371 & 3.503278 & -0.129585 \\ \mathrm{C} & -2.900624 & 2.948286 & 0.000143 \\ \mathrm{C} & -2.925611 & 1.501831 & 0.003155 \\ \mathrm{Re} & 1.189018 & -0.000037 & -0.182964 \\ \mathrm{~N} & -0.531189 & -1.322157 & -0.205044 \\ \mathrm{C} & -0.474421 & -2.685085 & -0.217698 \\ \mathrm{C} & -1.572473 & -3.503228 & -0.129065 \\ \mathrm{C} & -2.900793 & -2.948187 & -0.000225 \\ \mathrm{C} & -2.925712 & -1.501731 & 0.002622 \\ \mathrm{C} & -1.776034 & -0.744691 & -0.097508 \\ \mathrm{C} & 1.482869 & 0.000112 & 1.665410 \\ \mathrm{O} & 1.630938 & 0.000241 & 2.827697 \\ \mathrm{C} & 2.558087 & -1.363020 & -0.354729 \\ \mathrm{O} & 3.385780 & -2.178750 & -0.457438 \\ \mathrm{C} & 2.558202 & 1.362836 & -0.355093 \\ \mathrm{O} & 3.385912 & 2.178534 & -0.457767 \\ \mathrm{H} & -1.442772 & -4.581528 & -0.146959 \\ \mathrm{H} & -3.893847 & -1.021801 & 0.091533 \\ \mathrm{H} & -3.893710 & 1.021973 & 0.092861 \\ \mathrm{H} & -1.442657 & 4.581572 & -0.147651 \\ \mathrm{H} & 0.518195 & 3.113260 & -0.306908 \\ \mathrm{H} & 0.518193 & -3.113333 & -0.305368 \\ \mathrm{O} & -3.945632 & -3.652071 & 0.099119 \\ \mathrm{O} & -3.945374 & 3.652216 & 0.100158\end{array}$


Table S19. Calculated structure of ${ }^{2}\left[\operatorname{Re}\left(4 \mathrm{DHBP}^{-}\right)(\mathrm{CO})_{3}(\mathrm{DMF})\right]^{0}$.

$\begin{array}{cccc}\mathrm{C} & 1.989204 & -0.728285 & 0.191523 \\ \mathrm{~N} & 0.828554 & -1.316673 & -0.313473 \\ \mathrm{C} & 0.775022 & -2.660526 & -0.413733 \\ \mathrm{C} & 1.800537 & -3.510959 & -0.043239 \\ \mathrm{C} & 2.989184 & -2.924301 & 0.468941 \\ \mathrm{C} & 3.084016 & -1.555148 & 0.584269 \\ \mathrm{Re} & -0.776381 & 0.055988 & -0.870066 \\ \mathrm{~N} & 0.843933 & 1.345088 & -0.172637 \\ \mathrm{C} & 0.809551 & 2.692990 & -0.139878 \\ \mathrm{C} & 1.844088 & 3.487821 & 0.318396 \\ \mathrm{C} & 3.018920 & 2.836023 & 0.781112 \\ \mathrm{C} & 3.096178 & 1.461156 & 0.756846 \\ \mathrm{C} & 1.995960 & 0.693200 & 0.270599 \\ \mathrm{C} & -2.099795 & 1.436814 & -1.162754 \\ \mathrm{O} & -2.901548 & 2.267906 & -1.341860 \\ \mathrm{C} & -0.259542 & 0.152530 & -2.699114 \\ \mathrm{O} & 0.059756 & 0.211875 & -3.822576 \\ \mathrm{C} & -2.111872 & -1.272221 & -1.308203 \\ \mathrm{O} & -2.920542 & -2.071747 & -1.576665 \\ \mathrm{H} & 1.750571 & 4.569158 & 0.319780 \\ \mathrm{H} & 3.996780 & 0.973210 & 1.110070 \\ \mathrm{H} & 3.995881 & -1.116389 & 0.971344 \\ \mathrm{H} & 1.689897 & -4.585675 & -0.146832 \\ \mathrm{O} & -1.203799 & -0.076452 & 1.334606 \\ \mathrm{C} & -2.345032 & -0.074797 & 1.867816 \\ \mathrm{H} & -3.253533 & 0.023197 & 1.264063 \\ \mathrm{~N} & -2.546521 & -0.187926 & 3.175923 \\ \mathrm{C} & -3.896046 & -0.165751 & 3.736837 \\ \mathrm{H} & -4.629728 & -0.060706 & 2.935524 \\ \mathrm{H} & -4.087103 & -1.096656 & 4.280577 \\ \mathrm{H} & -3.995805 & 0.676514 & 4.429477 \\ \mathrm{C} & -1.441145 & -0.333932 & 4.120430 \\ \mathrm{H} & -0.495832 & -0.326346 & 3.580179 \\ \mathrm{H} & -1.547229 & -1.278412 & 4.664370 \\ \mathrm{H} & -1.461503 & 0.491809 & 4.839294 \\ \mathrm{H} & -0.144657 & -3.073797 & -0.813109 \\ \mathrm{H} & -0.100928 & 3.156364 & -0.504146 \\ \mathrm{O} & 4.053261 & -3.688653 & 0.852377 \\ \mathrm{O} & 4.086536 & 3.543452 & 1.253202 \\ \mathrm{H} & 3.849758 & -4.627375 & 0.714459 \\ \mathrm{H} & 3.895536 & 4.493841 & 1.209456 \\ & & & \end{array}$


Table S20. Calculated structure of ${ }^{2}\left[\operatorname{Re}\left(4 \mathrm{DHBP}+\mathrm{H}^{+}\right)(\mathrm{CO})_{3}(\mathrm{DMF})\right]^{1+}$.

$\begin{array}{cccc}\mathrm{C} & 2.026195 & -0.612587 & 0.229050 \\ \mathrm{~N} & 0.891414 & -1.316964 & -0.174016 \\ \mathrm{C} & 0.875429 & -2.622208 & -0.132924 \\ \mathrm{C} & 3.186543 & -2.670053 & 0.747499 \\ \mathrm{C} & 3.175215 & -1.306692 & 0.693090 \\ \mathrm{Re} & -0.822993 & -0.081367 & -0.843884 \\ \mathrm{~N} & 0.768351 & 1.351586 & -0.340844 \\ \mathrm{C} & 0.648110 & 2.687685 & -0.450684 \\ \mathrm{C} & 1.652331 & 3.579536 & -0.109604 \\ \mathrm{C} & 2.861239 & 3.056412 & 0.373398 \\ \mathrm{C} & 3.008059 & 1.675665 & 0.494334 \\ \mathrm{C} & 1.946548 & 0.831705 & 0.132497 \\ \mathrm{C} & -2.212870 & 1.178620 & -1.299308 \\ \mathrm{O} & -3.053219 & 1.932775 & -1.585924 \\ \mathrm{C} & -0.314988 & -0.179653 & -2.685496 \\ \mathrm{O} & -0.001994 & -0.239260 & -3.807199 \\ \mathrm{C} & -2.104134 & -1.504468 & -1.114778 \\ \mathrm{O} & -2.880978 & -2.356774 & -1.280160 \\ \mathrm{H} & 1.491813 & 4.647238 & -0.220407 \\ \mathrm{H} & 3.943054 & 1.276548 & 0.865478 \\ \mathrm{H} & 4.056294 & -0.762390 & 1.009484 \\ \mathrm{O} & -1.170002 & 0.047557 & 1.336839 \\ \mathrm{C} & -2.296098 & 0.041975 & 1.912121 \\ \mathrm{H} & -3.221842 & -0.062498 & 1.338557 \\ \mathrm{~N} & -2.447834 & 0.158937 & 3.222408 \\ \mathrm{C} & -1.310647 & 0.316442 & 4.127828 \\ \mathrm{H} & -0.383121 & 0.308222 & 3.557801 \\ \mathrm{H} & -1.404388 & 1.264604 & 4.667090 \\ \mathrm{H} & -1.306255 & -0.504004 & 4.852584 \\ \mathrm{C} & -3.777836 & 0.137036 & 3.831536 \\ \mathrm{H} & -4.538421 & 0.008455 & 3.059464 \\ \mathrm{H} & -3.955577 & 1.077428 & 4.362777 \\ \mathrm{H} & -3.842220 & -0.691790 & 4.543682 \\ \mathrm{O} & 3.906778 & 3.834135 & 0.732550 \\ \mathrm{H} & 3.690651 & 4.773290 & 0.603828 \\ \mathrm{H} & -0.027675 & -3.124263 & -0.462213 \\ \mathrm{H} & -0.296370 & 3.059117 & -0.829031 \\ \mathrm{O} & 4.289373 & -3.307969 & 1.190901 \\ \mathrm{H} & 4.160797 & -4.271686 & 1.175189 \\ & 2.006680 & -3.480533 & 0.326360 \\ \mathrm{H} & 1.657539 & -4.126425 & 1.150987 \\ & -4.181235 & -0.482361\end{array}$


Table S21. Calculated structure of ${ }^{1}\left[\operatorname{Re}\left(4 \mathrm{DHBP}-\mathrm{H}^{+}\right)(\mathrm{CO})_{3}(\mathrm{DMF})\right]^{0}$.

$\begin{array}{cccc}\mathrm{C} & 1.952048 & -0.889705 & 0.126900 \\ \mathrm{~N} & 0.769754 & -1.353785 & -0.387961 \\ \mathrm{C} & 0.642894 & -2.699662 & -0.530728 \\ \mathrm{C} & 1.616689 & -3.607767 & -0.186940 \\ \mathrm{C} & 2.876783 & -3.171648 & 0.367348 \\ \mathrm{C} & 2.980912 & -1.734153 & 0.498102 \\ \mathrm{Re} & -0.787427 & 0.109120 & -0.848032 \\ \mathrm{~N} & 0.940716 & 1.285035 & -0.144994 \\ \mathrm{C} & 0.962599 & 2.631612 & -0.074131 \\ \mathrm{C} & 2.052160 & 3.351319 & 0.385578 \\ \mathrm{C} & 3.185517 & 2.638165 & 0.797689 \\ \mathrm{C} & 3.176257 & 1.243129 & 0.726352 \\ \mathrm{C} & 2.042553 & 0.587478 & 0.249727 \\ \mathrm{C} & -2.048703 & 1.560526 & -1.055894 \\ \mathrm{O} & -2.813300 & 2.432269 & -1.186909 \\ \mathrm{C} & -0.293678 & 0.265510 & -2.685596 \\ \mathrm{O} & 0.010492 & 0.361079 & -3.808852 \\ \mathrm{C} & -2.194234 & -1.118085 & -1.337832 \\ \mathrm{O} & -3.044539 & -1.852536 & -1.650354 \\ \mathrm{H} & 2.014229 & 4.435677 & 0.418646 \\ \mathrm{H} & 4.053404 & 0.692042 & 1.040157 \\ \mathrm{H} & 3.904954 & -1.337291 & 0.903071 \\ \mathrm{H} & 1.435314 & -4.668895 & -0.332269 \\ \mathrm{O} & -1.143112 & -0.080985 & 1.338501 \\ \mathrm{C} & -2.264017 & -0.058969 & 1.918523 \\ \mathrm{H} & -3.191415 & 0.073550 & 1.352578 \\ \mathrm{~N} & -2.413138 & -0.192048 & 3.229390 \\ \mathrm{C} & -1.274638 & -0.384560 & 4.126025 \\ \mathrm{H} & -0.351805 & -0.403032 & 3.548577 \\ \mathrm{H} & -1.239399 & 0.434187 & 4.852190 \\ \mathrm{H} & -1.391331 & -1.330586 & 4.664671 \\ \mathrm{C} & -3.738824 & -0.152240 & 3.845688 \\ \mathrm{H} & -4.499727 & 0.015190 & 3.081380 \\ \mathrm{H} & -3.779327 & 0.659965 & 4.578652 \\ \mathrm{H} & -3.939367 & -1.100454 & 4.354825 \\ \mathrm{O} & 4.303581 & 3.235898 & 1.265003 \\ \mathrm{H} & 4.196891 & 4.202387 & 1.265356 \\ \mathrm{O} & 3.805438 & -3.958680 & 0.707829 \\ \mathrm{H} & -0.300235 & -3.041991 & -0.944089 \\ \mathrm{H} & 0.069115 & 3.148788 & -0.403025\end{array}$




\section{References}

(1) Sheldrick, G. M.; SADABS, version 2007/2.

(2) Sheldrick, G. M.; Bruker AXS Inc.: 2007.

(3) Sheldrick, G. M.; Siemens Analytical Instruments, Inc.: Madison, WI, 1994.

(4) Vosko, S. H.; Wilk, L.; Nusair, M. Accurate Spin-Dependent Electron Liquid Correlation Energies for Local Spin-Density Calculations - a Critical Analysis. Can. J. Phys. 1980, 58, 1200-1211.

(5) Becke, A. D. Density-Functional Exchange-Energy Approximation with Correct Asymptotic-Behavior. Phys. Rev. A 1988, 38, 3098-3100.

(6) Lee, C. T.; Yang, W. T.; Parr, R. G. Development of the Colle-Salvetti Correlation-Energy Formula into a Functional of the Electron-Density. Phys. Rev. B 1988, 37, 785-789.

(7) Becke, A. D. Density-Functional Thermochemistry. 3. The Role of Exact Exchange. J. Chem. Phys. 1993, 98, 5648-5652.

(8) Stevens, W. J.; Basch, H.; Krauss, M. Compact Effective Potentials and Efficient Shared-Exponent Basis-Sets for the 1st-Row and 2nd-Row Atoms. J. Chem. Phys. 1984, 81, 6026-6033.

(9) Stevens, W. J.; Krauss, M.; Basch, H.; Jasien, P. G. Relativistic Compact Effective Potentials and Efficient, Shared-Exponent Basis-Sets for the 3rd-Row, 4th-Row, and 5th-Row Atoms. Can. J. Chem. 1992, 70, 612-630. (10) Cundari, T. R.; Stevens, W. J. Effective Core Potential Methods for the Lanthanides. J. Chem. Phys. 1993, 98, 5555-5565.

(11) Frisch, M. J. T., G. W.; Schlegel, H. B.; Scuseria, G. E.; Robb, M. A.; Cheeseman, J. R.; Scalmani, G.; Barone, V.; Mennucci, B.; Petersson, G. A.; Nakatsuji, H.; Caricato, M.; Li, X.; Hratchian, H. P.; Izmaylov, A. F.; Bloino, J.; Zheng, G.; Sonnenberg, J. L.; Hada, M.; Ehara, M.; Toyota, K.; Fukuda, R.; Hasegawa, J.; Ishida, M.; Nakajima, T.; Honda, Y.; Kitao, O.; Nakai, H.; Vreven, T.; Montgomery, J. A., Jr.; Peralta, J. E.; Ogliaro, F.; Bearpark, M.; Heyd, J. J.; Brothers, E.; Kudin, K. N.; Staroverov, V. N.; Kobayashi, R.; Normand, J.; Raghavachari, K.; Rendell, A.; Burant, J. C.; Iyengar, S. S.; Tomasi, J.; Cossi, M.; Rega, N.; Millam, N. J.; Klene, M.; Knox, J. E.; Cross, J. B.; Bakken, V.; Adamo, C.; Jaramillo, J.; Gomperts, R.; Stratmann, R. E.; Yazyev, O.; Austin, A. J.; Cammi, R.; Pomelli, C.; Ochterski, J. W.; Martin, R. L.; Morokuma, K.; Zakrzewski, V. G.; Voth, G. A.; Salvador, P.; Dannenberg, J. J.; Dapprich, S.; Daniels, A. D.; Farkas, Ö.; Foresman, J. B.; Ortiz, J. V.; Cioslowski, J.; Fox, D. J. In Gaussian 09; Gaussian, I., Ed. Wallingford, CT.

(12) Klamt, A.; Schuurmann, G. Cosmo - a New Approach to Dielectric Screening in Solvents with Explicit Expressions for the Screening Energy and Its Gradient. J. Chem. Soc., Perkin Trans. 2 1993, 799-805.

(13) Barone, V.; Cossi, M. Quantum Calculation of Molecular Energies and Energy Gradients in Solution by a Conductor Solvent Model. J. Phys. Chem. A 1998, 102, 1995-2001.

(14) Cossi, M.; Rega, N.; Scalmani, G.; Barone, V. Energies, Structures, and Electronic Properties of Molecules in Solution with the C-PCM Solvation Model. J. Comput. Chem. 2003, 24, 669-681.

(15) Kelly, C. P.; Cramer, C. J.; Truhlar, D. G. Aqueous Solvation Free Energies of Ions and Ion-Water Clusters Based on an Accurate Value for the Absolute Aqueous Solvation Free Energy of the Proton. J. Phys. Chem. B 2006, 110, 16066-16081.

(16) Kelly, C. P.; Cramer, C. J.; Truhlar, D. G. Single-Ion Solvation Free Energies and the Normal Hydrogen Electrode Potential in Methanol, Acetonitrile, and Dimethyl Sulfoxide. J. Phys. Chem. B 2007, 111, 408-422.

(17) Bartmess, J. E. Thermodynamics of the Electron and the Proton. J. Phys. Chem. 1994, 98, 6420-6424.

(18) O'Boyle, N. M.; Tenderholt, A. L.; Langner, K. M. J. Comp. Chem. 2008, 29, 839-845. 